University of Louisville

ThinkIR: The University of Louisville's Institutional Repository

Electronic Theses and Dissertations

$12-2006$

\title{
International social work best practices curriculum for schools of social work.
}

Stephen Ulrich

University of Louisville

Follow this and additional works at: https://ir.library.louisville.edu/etd

\section{Recommended Citation}

Ulrich, Stephen, "International social work best practices curriculum for schools of social work." (2006). Electronic Theses and Dissertations. Paper 1476.

https://doi.org/10.18297/etd/1476

This Doctoral Dissertation is brought to you for free and open access by ThinkIR: The University of Louisville's Institutional Repository. It has been accepted for inclusion in Electronic Theses and Dissertations by an authorized administrator of ThinkIR: The University of Louisville's Institutional Repository. This title appears here courtesy of the author, who has retained all other copyrights. For more information, please contact thinkir@louisville.edu. 


\title{
INTERNATIONAL SOCIAL WORK BEST PRACTICES CURRICULUM FOR SCHOOLS OF SOCIAL WORK
}

\section{By}

\section{Stephen Ulrich}

BSW, Brescia University, 1999

MSSW, University of Louisville, 2000

\author{
A Dissertation \\ Submitted to the Faculty of the \\ Graduate School of the University of Louisville \\ in Partial Fulfillment of the Requirements \\ for the Degree of \\ Doctor of Philosophy \\ Kent School of Social Work \\ University of Louisville \\ Louisville, Kentucky
}

December, 2006 
Copyright 2006 by Stephen Ulrich

All rights reserved 


\title{
INTERNATIONAL SOCIAL WORK BEST PRACTICES CURRICULUM FOR SCHOOLS OF SOCIAL WORK
}

\author{
By \\ Stephen Ulrich \\ BSW, Brescia University, 1999 \\ MSSW, University of Louisville, 2000 \\ A Dissertation Approved on
}

November 22, 2006

By the following Dissertation Committee:

Anna C. Faul, Ph.D., Dissertation Chair

Ruth Huber, Ph.D.

Joe Brown, Ph.D.

Anita Barbee, Ph.D.

Annette Sossou, Ph.D. 


\section{DEDICATION}

This dissertation is dedicated to my parents

Mr. Norman J. Ulrich

\section{And}

Mrs. Sharon A. Ulrich

who have given me invaluable lessons on the meaning of life. 


\section{ACKNOWLEDGEMENTS}

I would like to thank my committee chair, Dr. Annatjie Faul for the hours she spent of guidance and work helping me to complete this dissertation. I would also like to thank Dr. Ruth Huber, Director of the Kent School of Social Work Doctoral Program for her guidance and patience. I would also like to thank the other committee members, Dr. Joe Brown, Dr. Anita Barbee, and Dr. Annette Sossou, for your comments, assistance, and your countless hours of reading and rereading. I would also like to express my thanks to my partner, Tom Grant, for his understanding and patience during those times when there seemed to be no light at the end of the tunnel. He encouraged me and helped me to stick with it. Also, many thanks to my sister and brothers: Sandra Maurer, Larry Ulrich, and Randy Ulrich in Evansville, Indiana. Finally, I would like to thank the members of my cohort for their untiring support. 


\section{ABSTRACT}

\section{INTERNATIONAL SOCIAL WORK BEST PRACTICES CURRICULUM FOR SCHOOLS OF SOCIAL WORK}

\section{Stephen Wayne Ulrich}

\section{November 22, 2006}

In 1979, the U.S. President's Commission on Foreign Language and International Studies stated that to function successfully in the next century, all adults would need more knowledge about our interdependent world, awareness of other peoples, and greater sensitivity to global attitudes and customs. Social work is deeply rooted in the tradition of promoting social justice and in the profession's commitment to concern for culturally diverse groups. It is increasingly felt that social workers must acquire skills and attitudes that will enable them to effectively intervene with clients from diverse cultures and ethnic backgrounds.

The inclusion of international content into social work curriculum varies widely in United States social work programs and curriculum approaches used. In order to assess the current status quo of International Social Work teaching practices curriculum in the United States and Puerto Rico, a survey was designed using Dillman's (2000) Tailored Design Theory and placed on the Internet utilizing PHP Surveyor. The format of the survey included three distinct sections: demographic information, format of international social work curriculum, and infusion of 
international social work content. Deans or directors of international social work programs in CSWE accredited schools of social work were invited to participate.

The results of the study demonstrated what the literature had proposed: international social work curriculum varies greatly from social work program to social work program. Ninety-one deans or directors out of 186 responded to the survey. Seventy-seven percent of the respondents categorized their universities as public and $63 \%$ as urban. Seventy-one offer international social work either through a specific course or infusion into the social work curriculum. Eight do not offer international social work but are in the process of offering. Respondents rated the international social work curriculum and the infusion of eight key areas of international social work curriculum on 1-7 Likert scales and were offered opportunities to explain their ratings. Teaching practices were assessed and utilized to create a second survey with anchor points of unacceptable, acceptable, and exemplary. 


\section{TABLE OF CONTENTS}

Page

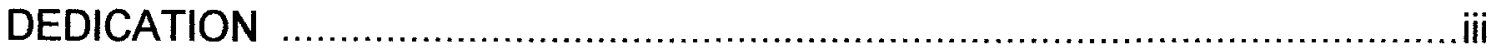

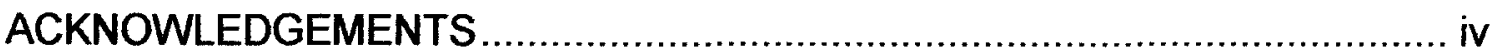

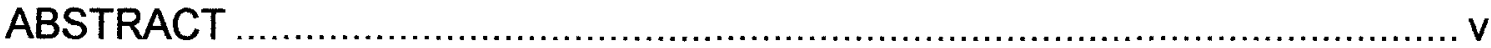

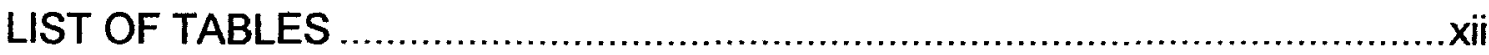

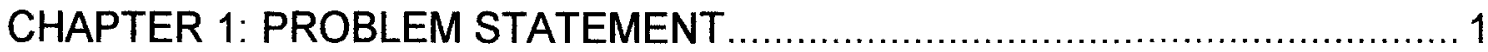

Complexity of Defining International Social Work ................................. 3

Internationally Related Domestic Practice and Advocacy .............. 5

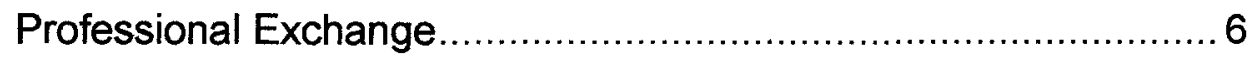

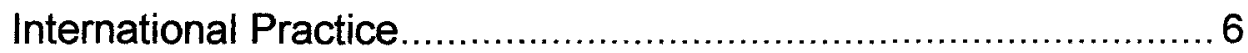

International Policy Development and Advocacy ....................... 7

Twentieth Century History: Impact on International Content.................... 7

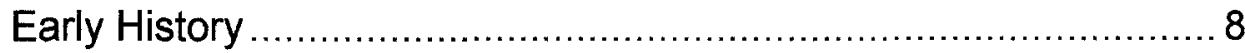

World War II - 1960's: Relief and Development ........................ 9

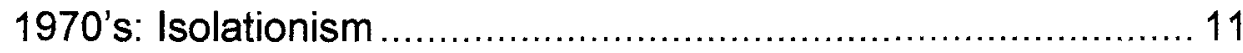

1990's: Revitalization? ............................................................. 12

History of CSWE's Emphasis on International Social Work Curriculum ... 14

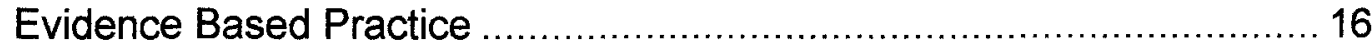

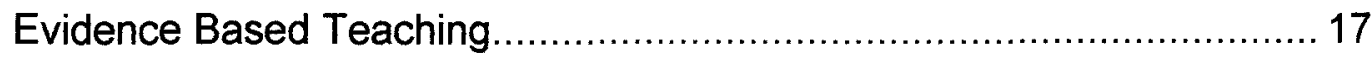

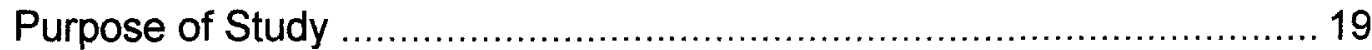

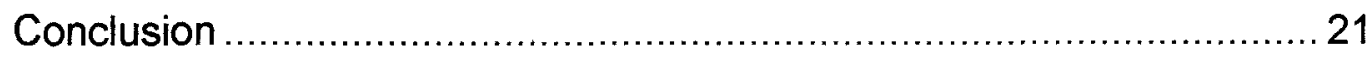

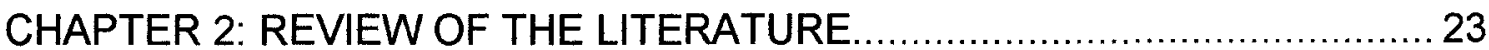


Universalism vs. Cultural Relativism ........................................ 25

Modeling in Social Work Education ........................................... 27

Models of International Social Work Education............................ 28

Contrasting Similarities and Differences of the Models ............... 29

Reasons for International Studies ..................................................... 36

Strategies Designed for Implementing International Social Work Into

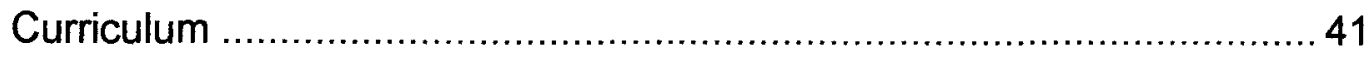

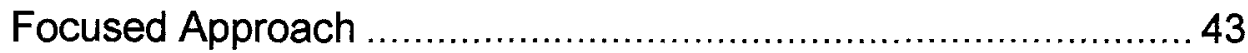

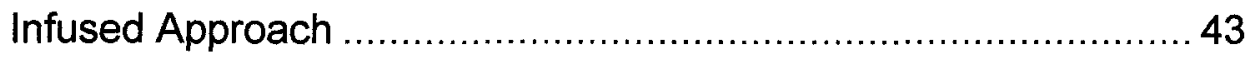

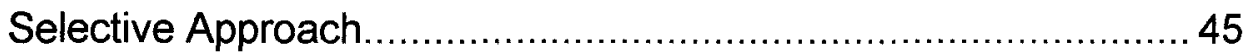

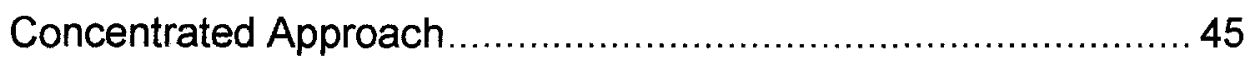

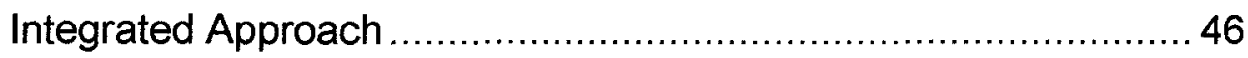

Contrasting Similarities and Differences in Strategies Designed for Implementing International Social Work Into Curriculum ....................... 47

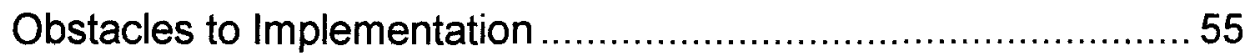

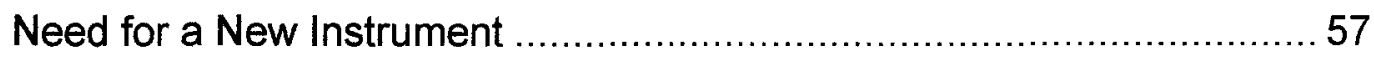

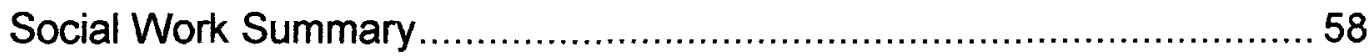

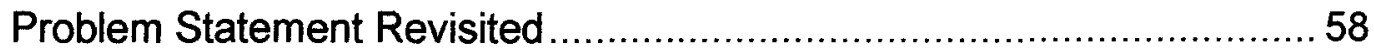

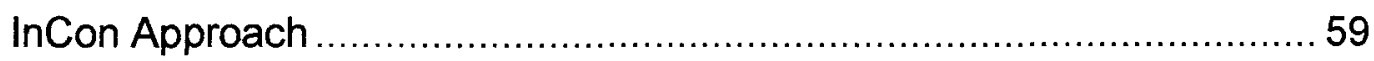

2002 Educational Policy and Accreditation Standards ................61

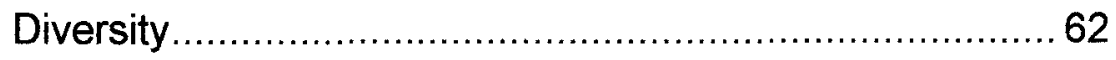

Populations at Risk/Social and Economic Justice ............66 63 
Human Behavior in the Social Environment 63

Social Welfare Policy and Services................................ 63

Cross-Cultural Knowledge and Skill ...............................63

Values and Ethics ....................................................... 63

Social Policies and Problems.......................................... 64

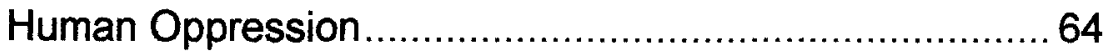

Optimal Outcomes for the InCon Approach to International Social Work

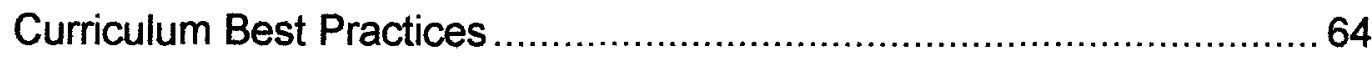

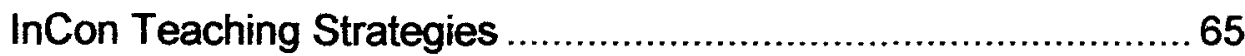

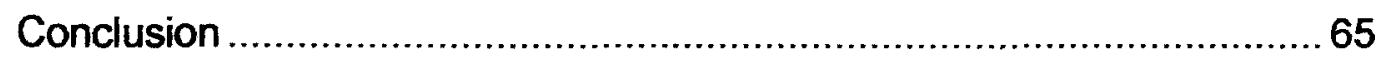

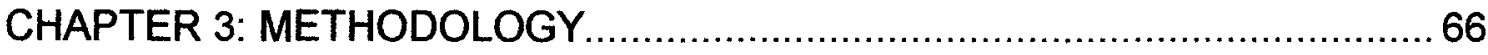

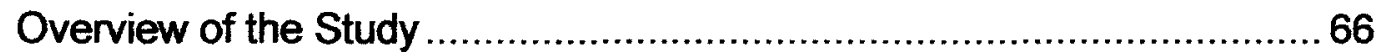

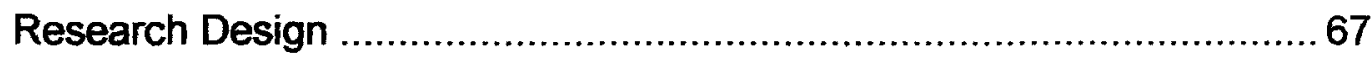

Objective 1: Content Analysis and Synthesis of the Literature......67

Objective 2 \& 3: Current Status Quo of International Social Work

Teaching Practices and Criteria for Anchor Points......................68

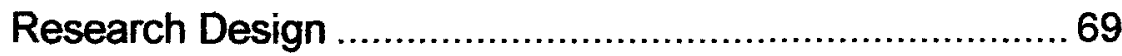

Data Collection Tool.......................................................... 75

Sampling Design......................................................... 76

Recruitment of the Sample............................................... 76

PHP Surveyor …....................................................... 77

Issues of Confidentiality/Informed Consent .......................78

Benefits and Risks .................................................... 78 
Conclusion

Demographics of the Respondents 80

Format of International Social Work Curriculum 83

Format-Infused or Offered as Specific Course 84

Format-Not Currently a Component but in Process 86

Format-Offered as Core Within Specialization 87

Format-Offered as Elective With Field Trip 88

Format-Offered as Elective Without Field Trip 89

Format-Limited to Field Trips 90

Format-Offered as Specialization Without Infusion 91

Format-Offered as Specialization With Infusion 92

Format-Offered as Core, Elective, and Infused 93

Format-Practicum Abroad Offered. 94

Format-Technology Used to Enhance 95

Summary of International Social Work Curriculum Format 96

Infusion of International Social Work Content 99

Infusion-Diversity Infused 99

Infusion-Populations at Risk/Economic Justice Infused 101 Infusion-Infusion-Human Behavior in the Social Environment Infused 102

Infusion-Social Welfare Policy Infused 103

Infusion-Cross-Cultural Knowledge and Skills Infused 105 
Infusion-Values and Ethics Infused........................................ 107

Infusion-Social Problems Infused ........................................ 108

Infusion-Human Oppression Infused ..................................... 109

Summary of Infusion of International Social Work Content......... 111

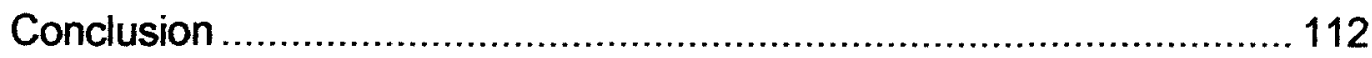

CHAPTER 5: DISCUSSION, CONCLUSIONS, AND IMPLICATIONS FOR

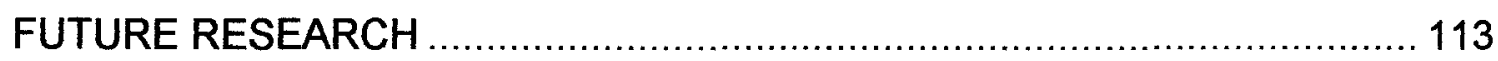

Summary, Discussion, and Conclusions ....................................... 113

Implications for Social Work Education and Practice.......................... 115

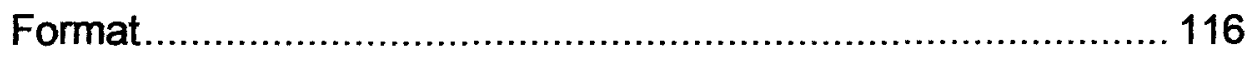

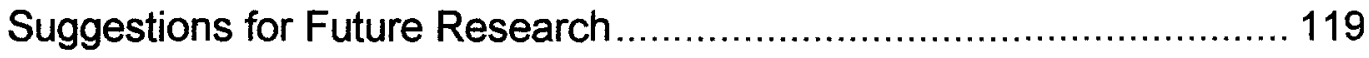

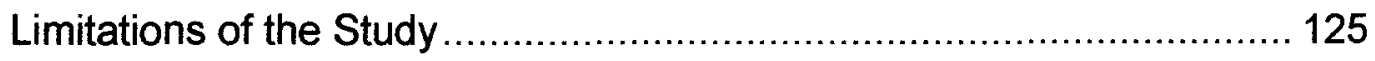

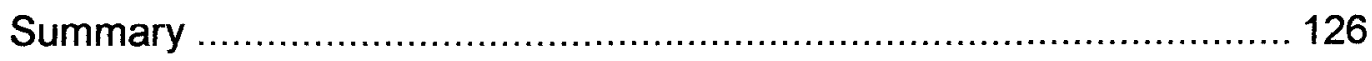

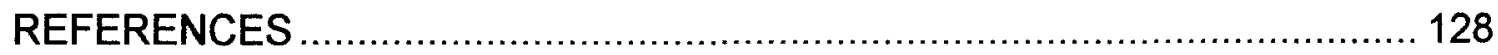

APPENDIX A

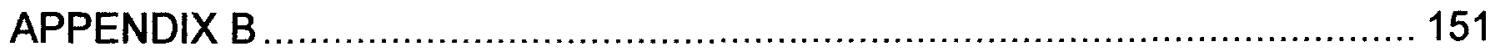

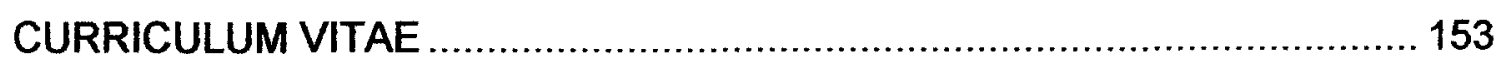




\section{LIST OF TABLES}

TABLE

PAGE

1. Twentieth Century History's Impact on International Content....................... 13

2. Dominant Values Associated With Three Models ...............................31

3. Social Change Goals Associated With Three Models .........................32

4. Pressure For Social Change Associated With Three Models .................33

5. Perceived Contributions of Social Work With Three Models ...................34

6. Dominant Intervention Modes Associated With Three Models ...................35

7. Primary Targets of Social Intervention Associated With Three Models ......... 36

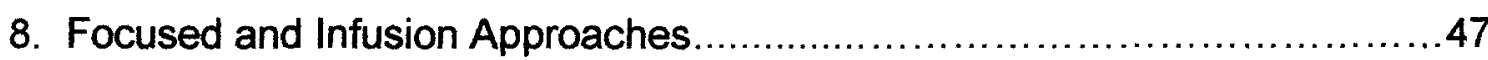

9. Proposed Curricula Model for Infusion Method ................................48

10. University of Connecticut Center for International Social Work Studies ......49

11. Educational Purposes Related With Estes' Alternative Approaches ...........50

12. Learning Objectives Related With Estes' Three Approaches ................51

13. General Structure and Location In Estes' Approaches. .....................52

14. Field Considerations Associated With Estes' Alternative Approaches........53

15. Proposed Curricula Model for Comparative Social Welfare In Estes............ 54

16. Curriculum Strategy Using InCon Approach .........................................61

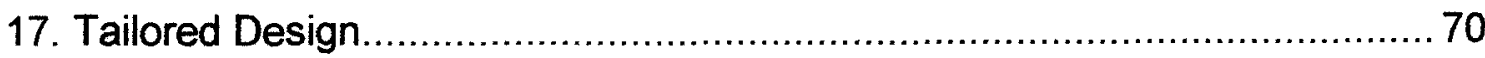

18. Descriptive Characteristics-Type of University ..................................... 81

19. Descriptive Characteristics-Degree Programs Offered ............................ 82 
20. Descriptive Characteristics

21. Descriptive Characteristics-Type of College/University Setting 83

22. Format-International Social Work Infused or Offered as Specific Course.... 85

23. Format-International Social Work Not Currently a Component....................86

24. Format-International Social Work Offered as Core Course .........................88

25. Format-International Social Work Offered as Elective With Field ................ 89

26. Format-International Social Work Offered as Elective Without Field ............90

27. Format-International Social Work Limited to Field ................................... 91

28. Format-International Social Work Offered as Specialization Without Infusion92

29. Format-International Social Work Offered as Specialization With Infusion ... 92

30. Format-International Social Work Offered as Core, Elective, Infused...........93

31. Format-Practicum Offered as Part of International Social Work ................. 94

32. Format-Technology Used to Enhance International Social Work ............... 96

33. International Social Work Curriculum Format Summary ...........................97

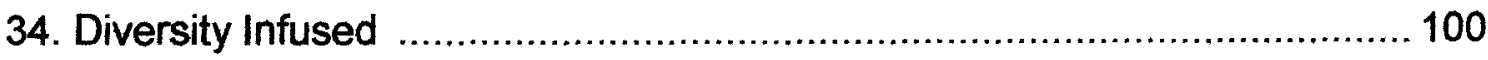

35. Populations at Risk/Economic Justice Infused .................................. 101

36. Human Behavior in Social Environment Infused ................................ 103

37. Social Welfare Policy Infused........................................................ 104

38. Cross-Cultural Knowledge and Skill Infused .......................................... 106

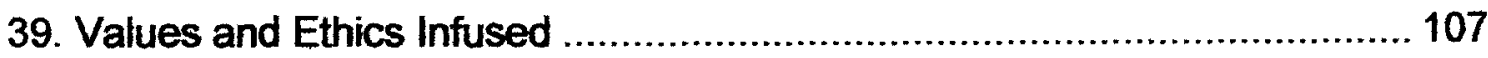

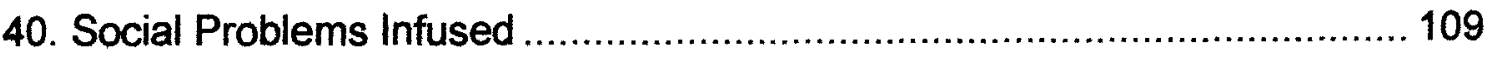

41. Human Oppression Infused ................................................................ 110

42. International Social Work Curriculum Infusion Summary.......................... 112 
43. International Social Work Teaching Practices Survey.

120 


\section{CHAPTER 1}

\section{PROBLEM STATEMENT}

In 1979, the U.S. President's Commission on Foreign Language and International Studies stated that to function successfully in the next century, all adults would need more knowledge about our interdependent world, awareness of other peoples, and greater sensitivity to global attitudes and customs. Social work is deeply rooted in the tradition of promoting social justice and in the profession's commitment to concern for culturally diverse groups. It is increasingly felt that social workers must acquire skills and attitudes that will enable them to effectively intervene with clients from diverse cultures and ethnic backgrounds (Sachdev, 1997).

The first part of this chapter will provide a glimpse into the complexity of defining international social work, including an understanding of Healy's 1988 four conceptual components. Successive sections will address (a) the impact on social work curricula of historical events in the $20^{\text {th }}$ century, (b) the history of the Council on Social Work Education's (CSWE) emphasis on international social work in social work curricula, (c) the relationship between evidenced based practice and evidence based teaching, (d) the purpose of this dissertation, and (e) a conclusion.

Interdependence cannot be escaped. Social problems flow back and forth across human made boundaries making it impossible to separate economic 
forces within nations from the impact of global economics. Social work educational programs need to include more international and cross-cultural content, both across the curriculum, within specific courses, and in specialized programs (Nagy \& Falk, 2000). According to Healy (1988), social work education in the United States has not adopted and implemented an international perspective and many social work educators view international concerns as peripheral to the mission of their schools. Social work has become a global profession as both policy and practice are shaped by global phenomena, even though social work education is impeded by the lack of a global perspective.

Healy (2001) delineated four areas of international responsibility and new opportunities for social work to have an impact on reshaping the global social environment:

1. International social forces and events have changed the makeup of social agency caseloads and affected domestic practice in many countries. New knowledge and competencies are demanded to cope with social problems and conditions that emerge from international interdependence.

2. Social problems are now shared by both more and less economically developed countries making mutual work and exchange more desirable.

3. The actions of one country (politically, economically, socially) directly and/or indirectly affect other countries' social and economic well-being.

4. There are enhanced opportunities for international sharing and exchanging information and ideas made possible by rapid developments in technology. 
Awareness may be the starting point for international studies. A recent study of university professors in 14 countries (England, Russia, Germany, Japan, South Korea, Chile, Australia, Brazil, Sweden, Israel, Hong Kong, Mexico, Netherlands, and the United States) found that "with the exception of the United States, international mindedness in the surveyed countries is quite high" (Lewis \& Altbach, 1996, p. 33).

The social work curriculum in the United States is regulated by the Council on Social Work Education (CSWE) through periodically issued curriculum policy statements. The Curriculum Policy Statement adopted in 1992 includes the following statement: "Effective social work programs recognize the interdependence of nations and the importance of worldwide professional cooperation" (CSWE, 1994, p.134).

The Complexity of Defining International Social Work

The definition of international social work has been the subject of considerable debate. There has been confusion over the use of the terms international, global, cross-national, intercultural, multi-cultural, cross-cultural, and comparative. All of these terms have been used to define various aspects of international social work and Healy (2001) noted that often these terms are used interchangeably.

The complexities in distinguishing between what is international and what is cross-cultural were emphasized by Nagy and Falk (2000), who suggested that a cross-cultural perspective includes cross-cultural understanding and cultural diversity. International social work, on the other hand, focuses on social 
development, comparative social welfare, a general world-view, and policy (Nagy \& Falk, 2000), although they did not think it meaningful to talk about global social work.

The profession's international identity crisis is not limited to the United States' paradigm. The International Federation of Social Workers (IFSW) represents the social work community as they address globalization challenges, and offer a generic definition of the cunundrum: "The holistic focus of social work is universal, but depending on cultural, historical, and socio-economic conditions, the priorities of social work practice will vary from country to country" (IFSW General Meeting in Montreal, Canada, July, 2000).

International social work remains a complex concept, actually comprised of a number of concepts. It is used to refer to comparative social welfare, international practice, cross-cultural knowledge and understanding, intergovernmental work on welfare, concern and action on global social problems, worldwide collegiality among social workers, professional exchange, and a general worldview. If social work is going to succeed on the global scene, the profession needs to resolve its international identity crisis.

Dr. Lynne Healy's definition of international social work is adopted for this dissertation: international professional action and the capacity for international action by the social work profession and its members. International action has four dimensions: (a) internationally related domestic practice and advocacy, (b) professional exchanges, (c) international practice, and (d) international policy development and advocacy. The first two aspects ( $a$ and $b$ ) potentially involve all 
social workers, the third aspect (c) involves only a few, and the fourth (d) indirectly involves all social workers and directly involves a few (Figure 1). These four dimensions are now explained a little more fully.

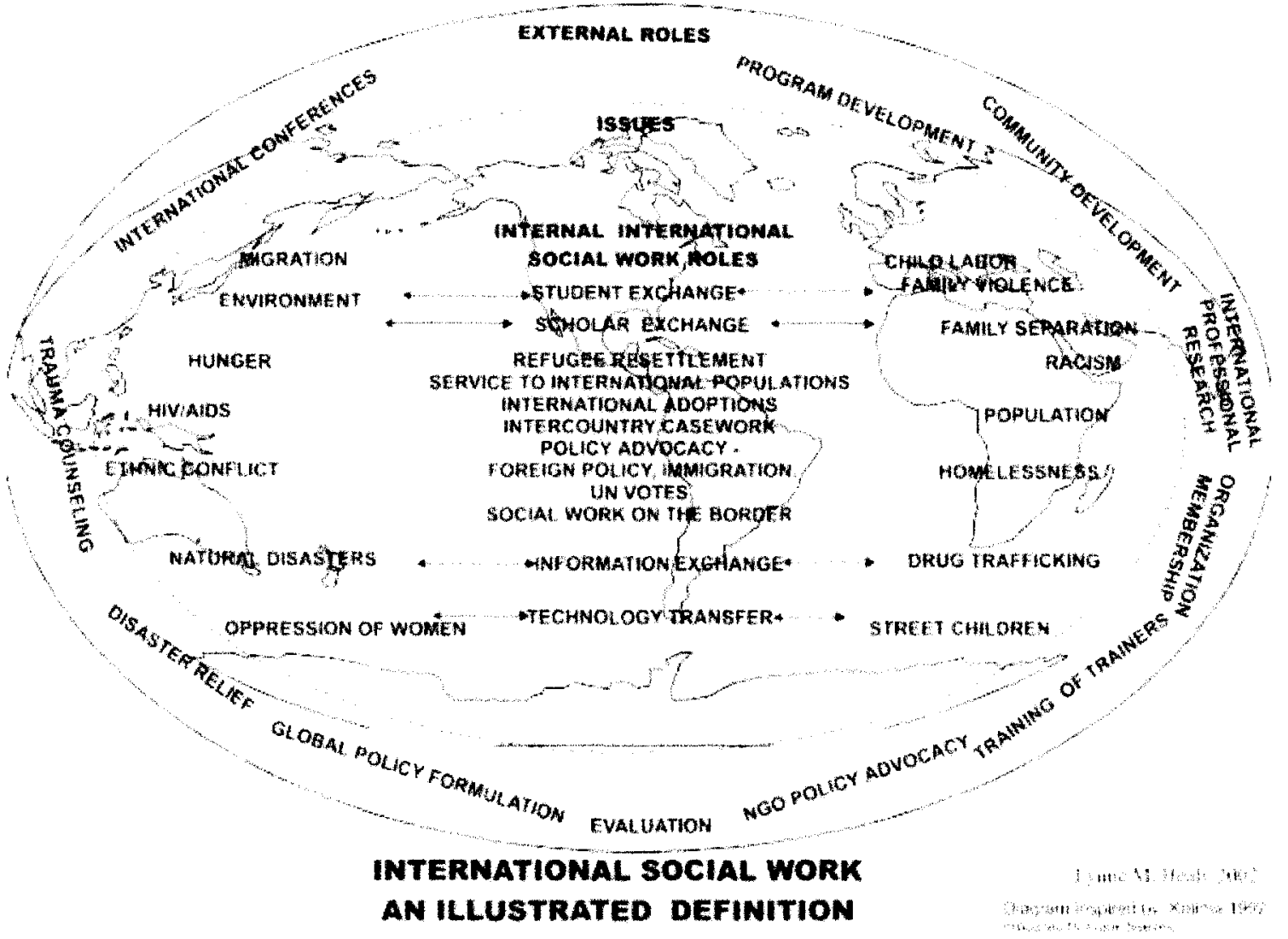

Figure 1. An illustrated definition of international social work. Internationally Related Domestic Practice and Advocacy

The first aspect of this definition is social work competence in internationally related aspects of domestic social work practice and professional advocacy. Increasingly, social workers are confronted with challenges and problems that have international dimensions, meaning that two or more countries 
are involved in some way in the policy issue or case. Examples are international adoptions, social work in border areas, and refugees.

A related responsibility is one that requires the willingness and the capacity of social workers to develop and promulgate positions on social aspects of their own countries' foreign policies, as well as national policies and their effect on peoples in other countries. Social workers must monitor legislation at all levels of government (Healy, 2001).

\section{Professional Exchange}

The second dimension is the capacity to exchange social work information and experiences internationally and then to utilize the knowledge and experience to improve social work practice and policy in one's own country. Examples include: (a) reading articles and periodicals in international journals that are relevant to the social workers' own fields, (b) participating in professional international exchanges that could be incorporated into one's own social work setting, and (c) collaborating with professionals in other countries.

\section{International Practice}

Healy's (2001) third aspect is the preparation of some professional social workers to contribute directly to international social work either through employment or volunteering in international development agencies. Social workers in international relief and development work make use of many skills gained through professional training. These skills are combined with a commitment to development, knowledge of international content, and communication skills. 


\section{International Policy Development and Advocacy}

The final aspect of Healy's (2001) definition is the capacity of the social work profession to declare and publicize positions on important social issues and contribute to the resolution of important global challenges and problems.

Examples include knowledge of women's issues around the world, political restraints in various countries that might render action possible or impossible, and communication skills.

Past studies have primarily focused on the need for an international dimension to social work curricula, although a few empirical studies have focused on best practice components of international social work curricula. Before attempting to create a tool to examine social work curricula for international social work content, it seems imperative to review the historical context in which the idea of international social work has evolved. Such historical reviews enable researchers and practitioners to observe the holistic connections between past and present, study how the present is informed by the past, and learn from the mistakes of the past to avoid repeating them or making similar mistakes in the future (Rubin \& Babbie, 2001).

\section{Twentieth Century History: Impact on International Content}

Social work education has been shaped by major historical events of the last century which included two world wars, the Cold War and its end, independence movements and the creation of new nations in Africa and Asia, creation of the United Nations, the civil rights movement in the United States and Gay rights movements worldwide, immigration, and the Vietnam War (Healy, 
2001; Hokenstad \& Midgley, 1997). Concurrently, over the past century, social work education has experienced ebbs and flows in the international contacts of social work educators and in opportunities for international practice and exchange. One constant has remained: debates continue over the importance of international social work curriculum, its relevance to practice, its purposes, and the appropriate focus or emphasis of its content. Thus, international social work education has been affected by four main periods in the twentieth century: (a) early history, (b) World War II-1960s: Relief and development, (c) the 1970s: Isolationism, and (d) the 1990s: Revitalization? (Healy, 2001). Each of these is explored below.

\section{Early History}

Formal social work education began at the turn of the century almost concurrently in the United States and Europe and by the 1920s it was also developing in South America, India, and South Africa. The first fully developed school of social work was founded in Amsterdam in 1899 and was followed by a school of social work in Germany in 1908. In the United States, the New York Charity Organization began a six-week summer school of philanthropic work in 1898 , a course which eventually lead to the creation of the Columbia School of Social Work. Schools in Boston (1904), and Chicago (1908) followed (Healy 1999). Internationally, South Africa opened a school of social work in 1924, the first school of social work was opened in South America in 1924, and the first school in India was founded in 1936. 
While social work emerged independently in Europe and the United States, social workers consulted one another to share issues and perspectives for common purposes. The first International Conference on Social Work was held in Paris in 1928 (First International Conference on Social Work, 1929). A section on social work education was held as part of the conference, and in 1929, the International Committee of Schools of Social Work was formed (Healy, 1999). Today, this committee is known as the International Association of Schools of Social Work. This was significant in that almost from the beginning, social work educators observed links to social work education and international collaboration and exchange.

The Great Depression of the 1930s found North America and Europe with few strategies for coping with high unemployment and the resulting family and community challenges and problems. Although some schools of social work were critical of the social policies of their time, they did not play important roles in social reform.

\section{World War II -1960s: Relief and Development}

The outbreak of World War II suspended significant contact among social workers internationally that continued after the war with the Communist takeover of Russia, China, and Eastern Europe. The takeover lead to the end of social work in several countries and impeded the development of social work in others. The socialist and community systems of Russia, China, and Eastern Europe did not recognize that social problems existed. The People's Republic of China shut down several schools of social work that existed in China before 1949, and soon 
after the takeover of Eastern Europe by the Soviet Union, social work programs were abolished and seen as unnecessary and bourgeois. Soviet domination isolated countries under its control and prevented professional contacts and exchanges.

The end of the war, however, also brought about opportunities for involvement in relief and development work and an influx of international students into U.S. social work programs. Many countries were interested in exchanging scientific methods and experiences in social welfare (Constable \& Mehta, 1994; Garber, 1997; Healy, 1999; Hokenstad \& Midgley, 1997). The United Nations was created and programs began to be offered under its auspices that included U.S. social work educators.

The United Nations Relief and Rehabilitation Agency created a systematic program that sent social workers to newly liberated nations to begin training so that health and welfare services could be developed or reestablished. Independence and national development in Asia and Africa supported the expansion of social work education around the world. A two-pronged approach was used: (a) sending social workers from the Unites States and Europe to provide assistance, and (b) providing scholarships to foreign students to graduate schools in the United States (Healy, 2001). Thus, in the 1960s, social work education identified two purposes for international social work education: (a) to train experts to go overseas, and (b) to provide social work education to students from Asia, Africa, and Latin America. 
Funds for curriculum in international social work education were expected to be provided through passage of the International Education Act of 1966 by Congress, but the act was never funded. Federal and foundation funding dropped dramatically between 1969 and 1979 as Americans' interest in international issues and careers declined in many fields, including social work.

\section{The 1970s: Isolationism}

A number of events lead to the decline in interest and funding in international issues and careers. The Vietnam War brought disillusionment with U.S. involvement in foreign affairs and the rise of anti-imperialism among newly independent nations fostered a movement to reject curriculum models borrowed from the United States and the West. American influences in South America were attacked as being irrelevant or damaging. The International Social Work journal took the unusual step of publishing an editorial declaring that the subject was "threadbare" and saying that no further articles on the topic would be published (Healy, 1999, p. 17), and wide spread rejection of Western models and a search for indigenous forms of social work began in South America.

At the same time, events in the United States (civil rights movement, urban renewal, war on poverty) captured the attention of American social workers. Domestic issues became the priority, and by the mid-1970s was the only agenda of American social workers. "We have enough problems at home was the new rationale for ignoring international curriculum, now seen as an exotic extra" (Healy, 1999, p. 17). 


\section{The 1990s: Revitalization?}

Since the 1990s, we seem to be a time of renewed international interest both in social work and generally. The end of the Cold War at the end of the 1980s, created new opportunities in Eastern Europe for the revival of social work services and educational programs. Social work educators have developed projects and engaged in consultation to assist Romania, Bulgarian Hungary, the Baltic Nations, and the republics of the former Soviet Union. A more gradual opening in China has lead to new opportunities. For almost 30 years there was little contact with China and the world relating to social work. By 1990 Chinese universities had reestablished the social sciences and exploration into social work began. By the middle 1990s, four Chinese universities had been given government approval to develop social work courses (Healy, 2001). Social work education today is present in 100 of the 191 member states around the world and there are schools of social work on every continent, although still absent in large parts of the sub-Saharan Africa, the South Pacific islands, and some republics of the former Soviet Union (Dominelli, 1993).

International communication and collaboration is becoming increasingly important as movement grows toward a worldwide economic and socio-political interdependence (Skolnick, Wayne, \& Raskin, 1999). The North American Free Trade Agreement (NAFTA), the unification of Europe, and the emergence of a global economy and large waves of immigration have convinced many that global interdependence is a reality. The world as a whole confronts many issues including AIDS, poverty, and women's rights. International issues are again 
defined as important and seen as a priority in social work education. As social work enters its second century, there are many challenges and areas for new opportunities: (a) fascination with a world economy, (b) increasing unemployment, (c) greater personal insecurity, (d) cutbacks in social programs, (e) scarcity of resources for meeting human needs, and, (f) the need for regional cooperation (Campfens, 2000; Healy, 2001; and Hokenstad \& Midgley, 1997;).

These four main periods are summarized in Table 1.

Table 1

Twentieth Century History's Impact on International Content

Early History: International Linkage and the Search for a Common Agenda Social Work Education Began

First Fully Developed Schools of Social Work were founded in Amsterdam in 1899 and Germany in 1908

Six-week program established in United States in 1898

Schools Established in Boston (1904) and Chicago (1908)

Schools established in South Africa (1924), South America (1924) and India (1936)

First International Conference 1928

First International Committee of Schools of Social Work formed 1929

Links between education and exchange

\section{World War II-1960s: Relief and Development}

End of World War II

Creation of United Nations Gives Rise to Expanded Opportunities Independence and national movements

Two pronged approach to Social Work Education

Promise of continued funding in international curriculum efforts International Education Act of 1966

\section{0s: Isolationism}

Vietnam War

Decline in international issues and careers

Rise of anti-imperialism

Rejection of western curriculum models

Domestic issues take priority

Joumal of Intermational Social Work ceases publication of articles 
End of Cold War

1990s: Revitalization

Rise of global economy

Waves of immigration

Global issues

International issues defined as important and priorities

\section{History of CSWE'S Emphasis on International Social Work Curriculum}

It is through the standards and accreditation processes that the Council on Social Work Education has the greatest potential to influence curriculum in any area, including international. Curriculum standards are based on an official Curriculum Policy Statement issued and periodically updated by the Council. The inclusion or absence of the mention of content areas in the policy statement serves as an important incentive to curriculum development.

Throughout the history of social work education in the United States, curriculum policy has been sporadic in the area of international social work (Healy, 1999). Of the 6 Curriculum Policy Statements adopted since the formation of the Council on Social Work Education and prior to 2001, 2 have contained no reference to international social work (1952 and 1984), 1 includes a single reference (1971), 1 contains an ambiguous phrase (1994), and one encourages programs to include international perspectives (1962). What follows are the references made in the policy statements concerning international social work in chronological order.

Considering the amount of international activity occurring during the 1960s, it is not surprising that the policy adopted in 1962 is very supportive of international perspectives. Eight goals are defined including the following: "the 
student perceives and is able to interpret social work as a profession dedicated to the promotion of individual and social welfare systems in his (sic) own and other societies"(CSWE, 1962, p. 2). The Policy and Welfare section stipulates that the outcomes to be achieved should enable the student "to identify, analyze, and appraise the movements and forces that have given expression and form to social welfare goals, nationally and internationally, with attention to contributions from the profession and leaders in political and social reform"(p. 3).

The policy statement redrafted in 1971 retained a single educational goal related to international curriculum. There are no references to other systems and the policy is related only to United States policies. The policy adopted in 1984 mentions nothing about international attitudes, outcomes, or knowledge. Its content focused on women, ethnic minorities and oppression coupled with the demanding requirements for specialization.

The Educational Policy and Accreditation Standards adopted in 1992 were tentative in recognizing the importance of international perspectives. Integrated in the Premises Underlying Social Work Education is the statement: "Effective social work programs recognize the interdependence of nations and the importance of worldwide cooperation." There is no mention of the words international or global. Thus, the 1962 Curriculum Policy Statement remains the only one up to 2001 in which the words "international" and "comparative" appear in a statement on curriculum policy. 


\section{Evidence Based Practice}

As a consequence of developments during the 1960s social work began the journey toward evidence-based practice. In the United States, the first half of the 20th century was characterized by the profession's search for a theoretical base with the result of adapting various theories. Mullen (2002) found that there are two meanings for evidence-based practice. The first was any practice established as having been effective through scientific research based on explicit criteria. Evidence-based practice (Gambrill, 1999; Sielgel, 1984; Thyer \& Wodarski, 1998) dictates that professional judgments and behavior be guided by two distinct but interdependent principles: (a) whenever possible, practice should be grounded on prior findings that empirically demonstrate that certain actions are likely to produce predictable, beneficial, and effective results, and (b) every client should be individually evaluated to determine the extent to which the results have been attained (Chambliss et al, 1998; Jayaratne \& Levy, 1979; Woody \& Sanderson, 1998).

The second meaning, in contrast, is based on David Sackett (1996) who described evidence-based medicine as the conscientious, explicit and judicious use of current best evidence in making decisions about the care of individuals. In the United States, evidence-based practice is associated with outcomes measurement, performance measurement, quality improvement, practice guidelines, and best practices. 
Evidence based practice (EBP), according to the School of Allied Medical Professions at the Ohio State University Medical Center involves a five step process:

1. Decide what information you need and formulate an answerable question.

2. Search for the best evidence to answer the question.

3. Critically appraise the evidence for validity, impact, and applicability.

4. Integrate the appraisal with your clinical expertise and client priorities.

5. Evaluate intervention effectiveness.

In all societies, social workers intervene to improve social problems whether domestic or international. While social problems continue to increase, resources to challenge these problems continue to decrease. The practice of ensuring effective use of finite resources requires evidence-based practices (Mullen, 2002). Evidence-based social work teaches how interventions may be assessed and evaluated.

\section{Evidence Based Teaching}

Much attention has been given to evidence based practice with the idea that evidence and research can and should significantly influence teaching. For the Faculty of Education at the Nottingham Trent University in England (2004) this raises several questions:

1. What kind of evidence is necessary, who obtains it, and how?

2. In what kinds of involvement with evidence and research are teachers encouraged to engage? 
3. Do teachers improve their teaching when they use others' evidence or when they gather their own?

4. Do teachers improve their teaching more (and/or better) when they impose theory on practice or when they collaboratively and critically examine evidence of their own or others so as to reconstruct theory and their teaching independently?

5. Are improvements made when teachers adapt their teaching to the ideas of others?

If evidence-based teaching were a reality, then we would expect to see changes in social work education as it pertains to both domestic and international social work. According to the Centre for Evidence Based Social Service (2004), the following changes should occur:

1. There will be a well-qualified workforce with knowledge and expertise and this workforce will be up-dated regularly by training courses which makes reference to research in the nature and development of social problems and what is known empirically about the effectiveness of different approaches designed to address them.

2. There will be qualifying courses which would address and review literature on the effectiveness of services.

3. The profession will nurture a system of staff supervision which regularly draws upon research to inform decisions with questions such as, "why are we proceeding this way?' and "on what evidence?" 
4. Departmental meetings will include references to research on issues and challenges regionally, nationally, and internationally.

5. There will be a range of support for faculty in their efforts to keep abreast of research that is relevant to their areas of interest and expertise.

6. There will exist a range of collaborative efforts between social service agencies and universities.

Teaching and research are regarded as mutually reinforcing. Research can and should play a significant role in influencing practice. This is true in several disciplines including medicine, education, and social work where evidence based practice has also impacted evidence-based teaching. The approach is for teachers to apply research evidence that have proved to be effective to their teaching methods. Pertaining specifically to international social work curricula, are we advancing an international social work curriculum that has been tested and found to be effective? What is, or is there, a best teaching method for international social work curriculum? What is the best content to include in international social work curricula?

\section{Purpose of the Study}

Past studies have focused on the need for an international dimension to social work curricula, but few empirical studies have supported this component of social work. Few have studied the impact of study abroad or cross-cultural education that uses experiential learning. Even less has been written specifically about international cross-cultural experiences. The general purpose and aim of this study was to assess the teaching practices and current status of international 
social work curricula for schools of social work accredited by the CSWE to determine the emphasis on international social work and designing a tool to evaluate best practices. Toward that end, the Council On Social Work Education's 2002 Educational Policy and Accreditation Standards was used as a guideline and the following questions were posed:

1. What are the key areas of international social work best teaching practices that are based on the 2002 CSWE Educational Policy and Accreditation Standards?

2. What is the current status of International Social Work teaching practices in CSWE accredited MSW programs of Social Work?

3. How can these components be measured to differentiate between unacceptable, essential, and exemplary practice? (Huber, Borders, Badrak, Netting, \& Nelson, 2001)?

To identify the key areas of best practices in International Social Work, a content analysis was conducted on the CSWE 2002 Educational Policy and Accreditation Standards. After the key areas were identified, a synthesis of the literature revealed key areas, models, and ideas to create a better understanding of what constitutes unacceptable, essential, and exemplary teaching practices corresponding to the key areas of International Social Work. The following steps were taken: (a) a sense of the whole was obtained, (b) themes were identified, (c) a list of topics was constructed, (d) the literature was organized into topics, and (e) related topics were grouped. The final product of this synthesis constitutes the operational definitions of each of the eight key areas: diversity, 
cross-cultural knowledge and skills, social welfare, values and ethics, populations at risk, human oppression, social problems, and human behavior and the social environment.

Utilizing the synthesis of the literature and the key areas identified, a survey was created specifically designed for program directors and Deans of Masters level programs in the United States and Puerto Rico that were accredited by CSWE to assess the current status of international social work within the social work curriculum. The survey was placed on the Internet and invitations and reminders were sent about the survey and website to the directors or Deans of the 172 accredited master level programs and 18 currently in candidacy. Data analysis was conducted at the conclusion of data collection. This data analysis was used to create a second survey. The data analysis was the focus of establishing the anchor points of unacceptable, acceptable, and exemplary.

\section{Conclusion}

This chapter provided the rationale for undertaking this study and the importance of including international social work in social work education. I also provided an historical evolution of $20^{\text {th }}$ century events and their impact on international curriculum content as well as the history of the Council on Social Work Education's emphasis on international social work curricula. An introduction into evidence-based practices and how that is translated into evidence-based teaching was presented. A brief purpose of the study and an 
introduction to the research methodology used was presented. The next chapter reviews the literature and is followed by the research methodology. 


\section{CHAPTER 2}

\section{REVIEW OF THE LITERATURE}

The term "international" social work was first used in a paper at the First International Conference on Social Work in 1928. The Council on Social Work Education in the United States formed a working committee to develop a definition of international social work in 1956. The current literature focused on four major themes relating to international social work best practices curriculum: (a) social work values, (b) reasons for international studies curricula, (c) strategies for incorporating international studies into social work curricula, and (d) obstacles to implementation.

\section{Social Work Values}

The social work profession has a distinct value base which supercedes cultural and/or geographic boundaries and a common core of professional boundaries exists among all social workers. Social workers continue to demonstrate their sense of social responsibility by fighting for change and social justice in a world that has increasingly seen a rise in violence, injustice, and economic disparity (Abbott, 1990).

Critical social work values include a respect for human rights, support of self-determination, and a commitment to individual freedom (Bogo, 1988). Basic human rights contain the concepts of equality and respect for individual rights. Self-determination refers to individuals being able to utilize alternatives when 
making their own decisions. Social responsibility encompasses the idea that society has a responsibility to develop legislation, funding, and programs that promote and improve the well being of its members.

Common values are found in various codes of ethics from social groups through various countries. These common values include (a) commitment to the inherent worth and dignity of individuals, (b) commitment to equality and nondiscrimination, (c) multiple responsibilities of the profession (to self, clients, profession, employer, society at large, and co-workers), (d) self-determination and (e) confidentiality.

Boyle (1999) compared social work to Frost's poem, The Road Less Traveled. Boyle argued that while most social workers focus on more micro approaches to practice with individuals, there is a need throughout the United States for social workers who understand the positive values of cultural diversity to provide leadership to their communities and the profession and to work toward a healthy society with opportunities and appreciation for all ethnic groups.

The discussion of values and ethics in traditional social work tends toward analysis of the comparative value base between countries and the implications for individual practitioners (Abbott, 1990). Chapters in international social work books reinforce practitioner ethics perspectives through case studies and decision-making exercises. International social work, as an outgrowth of domestic practice methods, provides little foundation from which to analyze the morals of a new global dimension of service. Link (1999) suggested that, "codes 
of practice often miss the wider context of issues in terms of human rights"( $p$. 38).

Values are potentially both unifying and divisive factors in international social work. Social workers in all countries espouse commitment to professional values, and social work professional associations in many countries have adopted or are currently working on codes of ethics (Healy, 2001). The social work profession has come together through the International Federation of Social Workers to develop and adopt an international code of ethics, comprised of an International Declaration of Ethical Principles of Social Work and International Ethical Standards for Social Workers (IFSW, 1994, Appendix A). However, there is a strong current of criticism that social work values and ethical codes are too grounded in Western-oriented individualistic values to the exclusion of other perspectives.

\section{Universalism vs. Cultural Relativism}

An understanding of universalist and cultural relativist perspectives on values and ethics is a prerequisite for advancing discussion on ethics for a global profession. Two competing schools of thought within ethics are (a) the deontological school that stresses the importance of fixed moral rules that make an action inherently right or wrong and that principles should apply in all situations, and (b) the teleologist's view that ethical decisions should be made on the basis of the context in which they are made or on the basis of the consequences they create (Lowenberg, Dolgoff, \& Harrington, 2000). In the language of human rights, these are called universalist and the cultural relativist, 
respectively. In the universalist view (deontology) all individuals share the same inalienable rights (Mayer,1995) and culture is irrelevant. Cultural relativists (teleology) argue that culture is the singular source of the validity of moral right or wrong (Donnelly, 1984) and that members of one society may not condemn the practices of societies with different traditions.

Universalism and relativism can more usefully be seen as a continuum with mixed positions occupying the center. The International Federation of Social Workers code of ethics identifies with the middle ground. In the statement of the purposes of the International Declaration of Ethical Principles, the first is "to formulate a set of basic principles for social work, which can adapt to cultural and social settings" (IFSW, 1989, pg. 1). Gray (1988) identified as universal the profession of social work's mission of helping others, responding to human need, and the pursuit of social justice.

Those who live abroad will need to grapple with ethical situations when practices considered ethical in one culture or country are considered unethical in others. Donaldson (1996) implied that the question of doing harm should be used as a criterion to evaluate whether practices encountered when crossing cultural boundaries should be accepted.

In preparing for practice in today's interdependent world, social workers need to address and wrestle with the universalism-cultural relativism issue. This is only one piece of international social work. The various codes of ethics for social workers need improvement and reviewing to continue to serve as effective guidelines for international social work action. It seems clear that social work 
must reject a purely relativist stance and also move beyond ethical principles bound up in individualistic values. New values of world-mindedness and global social work competence must evolve to position the profession for assuming its responsibilities in an interdependent world. In knowledge, practice, policy, and advocacy, limits on values must be removed. Link (1999) identified four common principles that could apply to international social work: (a) be responsible in professional actions, (b) act in such a way that enhances people's lives, (c) focus on the process as well as the task, and (d) act with cultural understanding.

\section{Modeling In Social Work Education}

In social science, models refer to representations of social phenomena that exist in the real world (Estes, 1992). They can be expressed either as mental abstractions of perceptions and experiences or through symbols. The purpose of a model is to bring together isolated but incomplete perceptions into a more complete picture. The 'best' models are those that accurately represent processes that the model seeks to capture; thus accurate models permit more "right" decisions regarding future actions.

Social modeling can make an important contribution to human services. To manage complex systems, policy makers, advocates, and practitioners must: (a) bring together a variety of models, (b) translate the differences into a common language, and (c) determine the implications of each model for all decisions that must be made (Estes, 1992).

Social modeling can contribute to the social work values education of all social work students and is essential in the education of students for leadership 
roles in International Social Work. For Estes (1992), modeling serves four purposes:

1. Social models can be used to describe complex international forces that shape social work practice in an international context.

2. Social models can help students understand the interplay of international social, political, and economic forces that have an impact on human social behavior.

3. Social models help students anticipate or sometimes predict the likely outcomes associated with particular combinations of different elements of social models across time, space, and cultures.

4. Social models can help students plan effective strategies for achieving goals and objectives.

The dominant modeling process in human services tends to be intuitive and less formal. Many difficult decisions are made through formal observations. While these can be generally correct in some situations, some choices fail to achieve their goals.

\section{Models of International Social Work Education}

Estes (1992) provided three models of international education in social work: Social Welfare, Social Development, and New World Order. The Social Welfare model has its origins in comparative social policy, comparative social research, and cross-cultural approaches to practice. This model draws knowledge from all social science disciplines and is oriented to understanding variation in human systems. 
The Social Development Model has community organization and practice as its origins. The primary focus of this model draws knowledge that is to provide a framework for identifying and acting upon underlying causes of powerlessness and social inequality. This model is both micro and macro in practice and is multidisciplinary and cross-cultural in construction (Estes, 1992). The goal of this model is to guide collective action with the purpose of eliminating all forms of social oppression, economic injustice, and international and national violence.

The New World Order Model suggests that social, political, economic, and ecological problems facing us are rooted in fundamental inequalities that presently exist in international institutions. This model is oriented to restructuring global social, economic, political, and ecological order. The principles that guide this model emphasize maximum participation of people, the pursuit of peace, meeting the basic needs of people globally, and environmental protection (Estes, 1992). This model advocates for global sharing instead of global squandering of resources, cooperation instead of competition in all international activity, and conservation instead of exploitation of the natural environment.

\section{Contrasting Similarities and Differences Of The Models}

The previous section introduced three models of internationalizing social work education. All three models are conceptually rich and offer something uniquely distinct and valuable. In this section, I focused on contrasting the similarities and the differences of the three models which are summarized in Tables 2 through 7 . The tables compare the models along the following dimensions: dominant values, social change goals, perceived sources of 
pressure for social change, perceived contributions, dominant interventions, and primary targets of social intervention.

The social welfare model, through carefully conducted policy analysis, seeks to help students understand similarities and differences in the social processes that inform welfare development across time and in different societies. The primary skills emphasized in this model are critical thinking, knowledge of social welfare programs, and comparative research. Through exposure to persons of diverse cultural backgrounds, this model assists students to better understand and respond to unique socio-cultural forces that shape human need. The goal is to ensure sensitivity of larger systems to the needs of minority populations that the larger systems serve. This model embodies basic social values and embraces the institutional basis of professional social work activity. The primary targets of this model are individuals and families.

The social development model draws on the theory base of sociology, political science, economics, philosophy, education, and sometimes religion. The knowledge, values, and skill base of traditional social work practice is consistent on both national and international levels. The primary skills emphasized in this model are group work and community organization. Like the social welfare model, the social development model targets individuals and families but also expands to include small groups, neighborhoods, and communities.

The new world order model is closely associated with political science, economics, law, and ecology. The focus of this model is the present world order that is seen as being controlled by a relatively small number of wealthy countries 
that manipulate the international system for their own advantage. Less

developed countries are provided with limited opportunities for accelerating

development. The skills emphasized are visionary and express goals and

objectives that are committed to international change on a more incremental

basis.

Table 2

Dominant Values Associated With Three Models of Internationalizing Social

Work Education

\begin{tabular}{|c|c|c|}
\hline $\begin{array}{c}\text { The } \\
\text { Social Welfare } \\
\text { Model }\end{array}$ & $\begin{array}{c}\text { The } \\
\text { Social Development } \\
\text { Model }\end{array}$ & $\begin{array}{c}\text { The } \\
\text { New World Order } \\
\text { Model }\end{array}$ \\
\hline $\begin{array}{l}\text { The central values found in } \\
\text { social welfare model include: } \\
\text { (a) share communal } \\
\text { responsibility, } \\
\text { (b) self help, } \\
\text { (c) self sufficiency, } \\
\text { (d) unselfishness, } \\
\text { (e) humanitarianism, } \\
\text { (f) cooperation, } \\
\text { (g) self-determination, and } \\
\text { (h) distributive justice. } \\
\text { The social welfare model also } \\
\text { respects individual and group } \\
\text { differences and a commitment } \\
\text { to equal opportunity. } \\
\text { There is an effort to satisfy } \\
\text { basic social and material } \\
\text { needs. } \\
\text { This model designs a safety } \\
\text { net for the socially vulnerable } \\
\text { (e.g., elderly, disabled, sick, } \\
\text { and children). }\end{array}$ & $\begin{array}{l}\text { The central values found in } \\
\text { social development model } \\
\text { include: } \\
\text { (a) distributive justice, } \\
\text { (b) conscientization, } \\
\text { (c) cooperation, } \\
\text { (d) participation, } \\
\text { (e) non-exploitation, } \\
\text { (f) detribalization, and } \\
\text { (g) humanocracy. } \\
\text { These values are realized in } \\
\text { active participation of groups } \\
\text { participating in their own } \\
\text { liberation and empowerment. } \\
\text { Conscientization: insight into } \\
\text { the source of oppression } \\
\text { combined with acting } \\
\text { collectively to bring about } \\
\text { solutions. } \\
\text { Assists the disenfranchised to } \\
\text { attain or regain social, political, } \\
\text { and economic control of their } \\
\text { futures. Differences seen as a } \\
\text { source of unity and strength. }\end{array}$ & $\begin{array}{l}\text { The central values in new } \\
\text { world order include: } \\
\text { (a) unity of all humanity, } \\
\text { (b) minimization of violence, } \\
\text { (c) satisfying basic human } \\
\text { needs, } \\
\text { (d) human dignity, } \\
\text { (e) diversity and pluralism, } \\
\text { (f) participation. } \\
\text { Values are realized when } \\
\text { there is sharing instead of } \\
\text { squandering, cooperation } \\
\text { instead of competition, and } \\
\text { conservation instead of } \\
\text { exploitation. } \\
\text { Humanity viewed as protector } \\
\text { of environment. } \\
\text { Forgoing of individual wants } \\
\text { and needs in the interests of } \\
\text { satisfying collective wants and } \\
\text { needs. }\end{array}$ \\
\hline
\end{tabular}


Table 3

Social Change Goals Associated With Three Models of Internationalizing

Social Work Education

\begin{tabular}{|c|c|c|}
\hline $\begin{array}{c}\text { The } \\
\text { Social Welfare } \\
\text { Model }\end{array}$ & $\begin{array}{c}\text { The } \\
\text { Social Development } \\
\text { Model }\end{array}$ & $\begin{array}{c}\text { The } \\
\text { New World Order } \\
\text { Model }\end{array}$ \\
\hline $\begin{array}{l}\text { Satisfaction of basic } \\
\text { human needs. } \\
\text { Access to basic } \\
\text { resources on need rather } \\
\text { than ability to pay. } \\
\text { Extension of basic social } \\
\text { guarantees and } \\
\text { protections (e.g., health } \\
\text { and education). } \\
\text { Access to services seen } \\
\text { as entitlement. }\end{array}$ & $\begin{array}{l}\text { Greater participation of } \\
\text { people. } \\
\text { Transformation of } \\
\text { existing systems to more } \\
\text { inclusive and } \\
\text { participatory. } \\
\text { Access and participation } \\
\text { of all societal benefits. } \\
\text { Access to services seen } \\
\text { as basic right of } \\
\text { residency. }\end{array}$ & $\begin{array}{l}\text { Worldwide transformation } \\
\text { based on: } \\
\text { (a) active participation } \\
\text { (b) world peace } \\
\text { (c) alleviation of } \\
\text { suffering } \\
\text { (d) increased social } \\
\text { justice } \\
\text { (e) protection of } \\
\text { environment }\end{array}$ \\
\hline
\end{tabular}




\section{Table 4}

Pressure For Social Change Associated With Three Models of

Internationalizing Social Work Education

\begin{tabular}{|c|c|c|}
\hline $\begin{array}{c}\text { The } \\
\text { Social Welfare } \\
\text { Model }\end{array}$ & $\begin{array}{c}\text { The } \\
\text { Social Development } \\
\text { Model }\end{array}$ & $\begin{array}{c}\text { The } \\
\text { New World Order } \\
\text { Model }\end{array}$ \\
\hline $\begin{array}{l}\text { Recognition of new and } \\
\text { emerging needs and a } \\
\text { yearning to respond. }\end{array}$ & $\begin{array}{l}\text { Conscientization of the } \\
\text { oppressed. }\end{array}$ & $\begin{array}{l}\text { Crisis or collapse of } \\
\text { existing world order. }\end{array}$ \\
\hline $\begin{array}{l}\text { Political pressure from } \\
\text { disenfranchised groups. } \\
\text { Social conflict in an effort } \\
\text { to address inequalities. } \\
\text { Preference for social } \\
\text { harmony. } \\
\text { Desire to minimize } \\
\text { criticism. }\end{array}$ & $\begin{array}{l}\text { Recognition of } \\
\text { inequalities and action } \\
\text { undertaken to resolve. } \\
\text { Pressure for change, } \\
\text { often conflictual. } \\
\text { Elites reluctantly agree } \\
\text { on need for change. }\end{array}$ & $\begin{array}{l}\text { Crisis could result from: } \\
\text { (a) Orders inability to } \\
\text { cope with rigid } \\
\text { institutions, (b) } \\
\text { recognition of the need } \\
\text { for restructuring, or (c) } \\
\text { global catastrophe. }\end{array}$ \\
\hline
\end{tabular}




\section{Table 5}

Perceived Contributions of Social Work and Social Welfare in Promoting

Fundamental Social Change Associated With Three Models of

Internationalizing Social Work Education

\begin{tabular}{|l|l|l|}
\hline \multicolumn{1}{|c|}{ Social Welfare Model } & \multicolumn{1}{|c|}{$\begin{array}{c}\text { The } \\
\text { Social Development } \\
\text { Model }\end{array}$} & \multicolumn{1}{c|}{$\begin{array}{c}\text { Thew World Order } \\
\text { Model }\end{array}$} \\
\hline $\begin{array}{l}\text { Social Work and Social } \\
\text { Welfare seen as } \\
\text { worldwide movements. }\end{array}$ & $\begin{array}{l}\text { This model seeks to set } \\
\text { free social, economic, } \\
\text { and political potential that } \\
\text { exists in individuals and } \\
\text { communities. }\end{array}$ & $\begin{array}{l}\text { Social workers with other } \\
\text { disciplines join to: (a) } \\
\text { promote recognition for } \\
\text { change in existing social } \\
\text { order, (b) serve as } \\
\text { leaders for the direction } \\
\text { of change, (c) manage } \\
\text { the change process, (d) } \\
\text { catalysts for needed } \\
\text { social change. }\end{array}$ \\
$\begin{array}{l}\text { Through a complex } \\
\text { change process, social } \\
\text { services seek to actualize } \\
\text { and stabilize that change impact of } \\
\text { with a view toward long- } \\
\text { term reform. }\end{array}$ & $\begin{array}{l}\text { Potentials for } \\
\text { development may be in } \\
\text { latent stages. } \\
\text { change and, (e) refocus } \\
\text { change efforts in keeping } \\
\text { with original goals and } \\
\text { objectives. }\end{array}$ \\
$\begin{array}{l}\text { Social workers and social } \\
\text { welfare see as } \\
\text { instruments for } \\
\text { redistributing resources. }\end{array}$ & $\begin{array}{l}\text { social change are based } \\
\text { in knowledge, values, } \\
\text { and skill base found in } \\
\text { social work practice. }\end{array}$ & $\begin{array}{l}\text { Social workers give } \\
\text { focused leadership of } \\
\text { new systems to eliminate } \\
\text { social and material } \\
\text { deprivation. }\end{array}$ \\
\hline
\end{tabular}




\section{Table 6}

\section{Dominant Intervention Modes Associated With Three Models of}

\section{Internationalizing Social Work Education}

\begin{tabular}{|c|c|c|}
\hline $\begin{array}{c}\text { The } \\
\text { Social Welfare } \\
\text { Model }\end{array}$ & $\begin{array}{c}\text { The } \\
\text { Social Development } \\
\text { Model }\end{array}$ & $\begin{array}{c}\text { The } \\
\text { New World Order } \\
\text { Model }\end{array}$ \\
\hline $\begin{array}{l}\text { Organization and delivery } \\
\text { of services to every } \\
\text { increasing group of eligible } \\
\text { recipients. } \\
\text { Intervention strategies } \\
\text { include: } \\
\text { (a) satisfaction of basic } \\
\text { social and material needs, } \\
\text { (b) enhancement of the } \\
\text { capacity for participation in } \\
\text { social and economic } \\
\text { systems, } \\
\text { (c) promotion of self- } \\
\text { sufficiency, and } \\
\text { (d) empowerment of people } \\
\text { to act in their own interest. } \\
\text { Services focus on } \\
\text { provision, prevention, and } \\
\text { enrichment. } \\
\text { Large numbers of } \\
\text { managers needed for skills } \\
\text { required in development, } \\
\text { management, and } \\
\text { refinement of complex } \\
\text { systems. } \\
\text { System employs large } \\
\text { number so planner, } \\
\text { researcher, and evaluators } \\
\text { with their goal to increase } \\
\text { effectiveness and } \\
\text { efficiency. }\end{array}$ & $\begin{array}{l}\text { Broad array of social work } \\
\text { methods to promote social } \\
\text { participation. } \\
\text { Conscientization-insight } \\
\text { into sources of oppression } \\
\text { and willingness to act } \\
\text { collectively. } \\
\text { Institution building-the } \\
\text { process of establishing new } \\
\text { resources to larger } \\
\text { numbers of people. } \\
\text { Conflict resolution-efforts } \\
\text { directed at resolving } \\
\text { grievances between more } \\
\text { and less powerful groups. } \\
\text { Nation building-process of } \\
\text { integrating and } \\
\text { transforming into nation as } \\
\text { a whole. }\end{array}$ & $\begin{array}{l}\text { Activities are multifaceted } \\
\text { and drawn from all areas of } \\
\text { social work skills. } \\
\text { Nation building-process of } \\
\text { integrating and } \\
\text { transforming into nation as } \\
\text { a whole. } \\
\text { World-building-the } \\
\text { process of integrating and } \\
\text { transforming goals at all } \\
\text { levels toward development } \\
\text { of people everywhere. } \\
\text { All activities combine } \\
\text { collaboration efforts from a } \\
\text { broad spectrum of } \\
\text { disciplines that include } \\
\text { government, non- } \\
\text { government, groups, and } \\
\text { individuals. } \\
\text { Shared commitment to } \\
\text { fullest possible participation } \\
\text { of people in global change } \\
\text { and transformation. }\end{array}$ \\
\hline
\end{tabular}




\section{Table 7}

Primary Targets of Social Intervention Associated With Three Models of Internationalizing Social Work Education

\begin{tabular}{|c|c|c|}
\hline $\begin{array}{c}\text { The } \\
\text { Social Welfare } \\
\text { Model }\end{array}$ & $\begin{array}{l}\text { The } \\
\text { Social Development } \\
\text { Model }\end{array}$ & $\begin{array}{c}\text { The } \\
\text { New World Order } \\
\text { Model }\end{array}$ \\
\hline $\begin{array}{l}\text { Operates with a dual } \\
\text { client focus: } \\
\text { (a)values and priorities of } \\
\text { system and, } \\
\text { (b) individuals and } \\
\text { groups served. } \\
\text { Majority of clients are } \\
\text { individuals and families. } \\
\text { Groups, organizations, } \\
\text { and communities also } \\
\text { served. } \\
\text { Priority assigned to: } \\
\text { (a) age dependent and } \\
\text { other vulnerable groups } \\
\text { (sick children), } \\
\text { (b) groups oppressed } \\
\text { socially and, } \\
\text { (c) recent arrivals } \\
\text { (refugees) }\end{array}$ & $\begin{array}{l}\text { Individuals, groups, } \\
\text { neighborhoods, and } \\
\text { communities. } \\
\text { Focus is on provision and } \\
\text { prevention with some } \\
\text { change effort. } \\
\text { Attention is directed at } \\
\text { marginalized population } \\
\text { within larger communities } \\
\text { (homeless, migrants). }\end{array}$ & $\begin{array}{l}\text { Focus is the energizing of } \\
\text { peoples everywhere to } \\
\text { think globally with goal of } \\
\text { change actions that seek } \\
\text { broader system reform at } \\
\text { all levels. } \\
\text { Goal is pursued through } \\
\text { work with indigenous, } \\
\text { special interest, coalition } \\
\text { of and broad range of } \\
\text { groups functioning at } \\
\text { local, regional, national, } \\
\text { and international levels. }\end{array}$ \\
\hline
\end{tabular}

\section{Reasons for International Studies}

Social workers can broaden their understanding of problems and peoples by utilizing a more global perspective. Studying Ghana, Wilson (2000), came upon a West African proverb: "the world is like a mask dancing, we cannot see it well if we stand in one place" (p. 197). Applied to social work, neither social work 
educators nor students can fully comprehend the vastness of our global mission if we view the world only from classrooms, textbooks, and local service agencies.

The popular adage to think globally and act locally has been poorly incorporated by United States' social workers because the local orientation of the discipline, combined with the increasing demand for domestic services, naturally inhibits the ability to think globally. It is understandable that the immediate, dayto-day challenges presented by clients and communities within our own country take priority over enhancing the profession's ability to act globally. In researching Australian social work, Pawar (2000) purported that international social work is a field of professional practice that involves multination/transnational understanding, analysis, and strengthening of activities in five areas: (a) professionalization and development of social work, (b) macro and micro social development processes, social welfare policies, and human services, (c) values, knowledge-bases and practice methods, (d) similar and different roles of social workers, and (d) transferring and sharing of knowledge. Neither social work educators nor students can fully comprehend the vastness of our global mission if we view it only from our classrooms, texts, and local social service agencies.

Researchers (Healy, 1997; Hokenstad \& Midgely, 1997) emphasized that in spite of the increased challenges presented by globalization, the social work profession and educators have yet to assimilate the ramification of global interdependence. In addition, they suggest that global problems may need global interventions. It is important for the United States social work profession to address the challenges of globalization for several reasons: (a) global 
understanding - the profession addresses social problems domestically and internationally which are precipitated by global events, (b) global responsibilitythe United States is the most powerful country in the world and the profession should lead the struggle toward a more just world, (c) global ethics-to promote ethical debate and reflection, (d) global positioning-to enhance the profession's positioning as a profession, (e) global dialogue - to prepare the profession for interdisciplinary dialogue, and (f) global competency-develop competent social worker professionals for international practice in international settings and organizations.

The push within the profession for attention to international dimensions of social work is being reinforced by: (a) the increasingly more international nature of social work practice in the United States, (b) the profession's recognition that social work knowledge, values, skills have much to offer in finding long-term solutions to worldwide social problems, (c) the existence of an expanding international social welfare infrastructure, and (d) the increasing number of social workers engaged in international practice (Estes, 1992; Healy, 2001).

According to Estes (1992), there are five areas that speak to the importance of international social work. First, an international social work education has the possibility of broadening students' horizons to other cultures, socio economic and political systems, and diverse and multiple approaches to dealing with social problems. Second, international social work education can add insights into one's own country's values, cultural groups, and ideologies. Third, it allows for students to focus on particular countries. Fourth, it enhances 
the possibilities of international collaborative work not only in education, but also in practice, research, and community development. Finally, international social work brings into focus the question of how far American education, approaches, and techniques are appropriate for peoples from other cultures.

Gray (1988) concurred with Estes (1992) and expanded on Estes' ideas for international social work education. For Gray (1988), not only does international social work education prepare students for the reality of practice in an interdependent world, the education itself prepares students for current problems and helps them anticipate future needs and propose changes.

Social problems do not come to a sudden halt at the border. For Asamoah (1997),Bogo (1988), and Nagy (2000), social problems flow back and forth across national borders representing diverse and complex problems and challenges confronting our world. These include poverty, unemployment, ethnic conflict, environmental degradation, drugs, AIDS, and violations of human rights. A social development perspective appears to be appropriate to address these challenges, as western social work models do not currently address these challenges either locally or globally. The profession needs to set the goal of greater international participation for its curricula and practices because these common problems have a direct impact on the profession of social work and on the educational needs of students.

Examining popular movements, Campfens (1996) argued that there was an urgent need for the development of networks for social change. At the forefront of this development are social workers and other professionals. Their 
knowledge of health services, access to housing, job opportunities, and community-based organizations aid popular movements in forming linkages to address such global issues as environmentalism, feminism, human rights, and international peace.

Asamoah (1997), Goldstein (1986), Bogo (1988) and Garland (1988) have questioned the idea of exporting social policy and social work practice to other countries that are grounded in the Western paradigm. We cannot assume that our Western paradigm of knowledge and expertise is universally applicable. These scholars have cautioned that it may be in the best interest of other cultures to develop their own perspectives for social work practice and social policy. Others have studied the benefits to our culture from overseas contacts. Midgely (1990) suggested that international exchanges have broadened and increased our knowledge base. International social work education enables U.S. social workers to see the value of approaches from other countries, and assists us in adapting those approaches to practice in the United States or abroad. If United States social workers are to be successful in expanding their global horizons, then international social work cannot be isolated within the profession. Harris (1990) and Younes (1998) agree that the time has come for the social work profession to collaborate and learn from other cultures. 


\section{Strategies Designed for Implementing International Social Work Into}

\section{Curriculum}

The Council on Social Work Education (CSWE) regulates social work curriculum in the United States through periodically issued curriculum policy statements. At this time, no international content is required. Individual social work programs decide whether to include international content and under what structure. The inclusion of international content varies widely in U.S. social work programs and curriculum approaches used. Healy (2001) reported that the high degree of variation is due to the lack of accreditation standards for International Social Work. A typical approach is to develop a specialized course. It is more difficult to assess information regarding the infusion of international content into other courses. Healy (1997) reported that several initiatives encouraging and assisting curriculum development have been sponsored by the International Commission of the CSWE.

Although research proposes that international social work should be an essential component of social work curricula, there is no consensus regarding how to incorporate it. Researchers (Bogo, 1988; Estes, 1992; Healy, 1988 \& Johnson, 1996) suggested that schools should first assess how including international social work could contribute to the school's overall philosophy and then specify desired objectives. The desired objectives should include (a) course goals and learning objectives, (b) nature of the course, (c) skills that students are expected to acquire, (d) the education level of the students, (e) resources available to students for undertaking research, (f) the degree of originality 
expected of students, (g) available institutional resources, (g) field placement opportunities, (h) the extent of administrative support, and (i) competing pressures from other content areas. They found that the usual method of adding new materials to the social work curriculum was to create a new course, usually entitled International Social Welfare. Incorporating international social work content into existing courses is seldom considered.

Ideas about how international social work can be added to the curriculum vary. Depending on the needs and interest of the students, the teaching style and knowledge of the professor and adequate library resources, international content can be infused into existing curricula individually or in combination utilizing the following: (a) specific courses, (b) infused into existing courses, (c) independent studies, (d) specializations, (e) overseas field practica, (f) the presence of overseas foreign graduate students in the student body, $(\mathrm{g})$ individual faculty activities, (h) focus on existing problems, (i) field trips, (j) utilizing faculty from other nations, and (k) sending American students and faculty overseas (Healy, 1988; Bogo 1988; Estes, 1992; \& Johnson, 1996).

Nagy (2000) took the ideas of past researchers a step further, arguing that preparing workers for international positions requires expansion on the part of already existing programs. Worldwide contacts will increase cross-cultural knowledge, approaches, and methods. It appears that most students, however, focus on immediate concerns. The task is to make global problems relevant to students. Using the Internet to connect students to other students is possible, as well as linking faculty members and classes around the world. Estes (1992) and 
Healy (2001) had suggested five approaches for incorporating International

Social Work best practices into the social work curriculum: (a) focused, (b) infused, (c) selective, (d) concentrated, and (e) integrated.

Healy (2001) suggested that there are two major approaches to restructuring curriculum content: focused and infused. The focused approach has the advantage of depth where content can be explored more fully and students have the opportunity to research global problems. The infused approach offers two advantages. First, this approach allows for all social work students to be reached, not just those with a special interest. Second, this approach can move both students and the profession closer to the ideal of removing the concept of borders as a rigid barrier to learning social work.

\section{Focused Approach}

In examining international social work education, the primary focus is placed on content. The most common approach is the focused approach where specialized classes are organized on various international topics. This approach can be structured minimally or comprehensively. Minimally, a single course such as international social welfare may be offered. Comprehensively, a sequence of courses may be developed leading to a specialization.

\section{Infused Approach}

At the Wisconsin Council of Social Work Education Workshop in April 2003, Healy gave a presentation entitled Internationalizing Social Work Curriculum, in which she recommended the infusion approach for incorporating International Social Work into the social work curriculum. The infusion approach 
incorporates (a) infuse modules into existing courses, with emphasis on required courses, (b) set objectives for the international component that specify how international content will contribute to the course as a whole, (c) integrate domestic concerns with international wherever possible, and (d) integrate international issues into the student's role as both citizen and professional.

Within the infusion approach international learning is rooted in (a) course objectives, (b) course readings, (c) student assignments, (d) criteria for evaluation of student learning, (e) international content that strengthens and deepens core content, and ( $f$ ) curriculum planning infusion (Healy, 2003)

Optimal outcomes for international learning within the infusion approach should include (a) familiarity with history, scope, and functions of social work around the world, (b) knowledge of ways the profession is organized for international action through professional organizations, (c) knowledge of agencies involved in international social work, (d) awareness of global interdependence issues and challenges, (e) understanding of cultural diversity and migration, ( $f$ ) awareness of the impact of U.S. policy on other countries, (g) knowledge of sources for global data, (h) sensitivity to value dilemmas, (i) knowledge of human rights standards globally, and (j) the ability to analyze social policy and advocacy (Healy, 2003).

In Healy's (2003) infusion approach, she uses the Council On Social Work Education Educational Policy and Accreditation Standards (2002) as a basis for curriculum development. Emphasis is on the impact of culture in Human Behavior in the Social Environment, a rethinking of the approach to social policy 
to emphasize international issues, addressing international forces of oppression in an approach to economic and social justice, and including human rights in course content. Healy (2003) reported that the following aided in the process of internalizing course content: (a) accreditation standards that include content and outcomes, (b) new publications on International Social Work, and (c) the Internet at a source for information and a tool for communication

Estes (1992) suggested three distinct approaches to internationalizing social work curriculum: the selective approach, the concentrated approach, and the integrated approach. These are listed below.

\section{Selective Approach}

The selective approach to internationalizing social work curriculum has as its goal for students to gain a better understanding of the international dimensions of domestic social work issues. Students are required to participate in field placements that expose them to persons of diverse socio-cultural backgrounds. Thus students are helped to understand how race, culture, religion, and culture play important roles in lives. Students are also encouraged to find culturally appropriate methods for responding to the needs of persons considerably different from themselves. The selective approach is usually associated with electives and thus reaches only a limited number of students and has few demands on the resources of programs.

\section{Concentrated Approach}

The concentrated approach to internationalizing social work curriculum has as its goal identifying for students distinct fields of practice: (a) international 
education, (b) international social work, (c) international social welfare, and (d) international social development. By identifying these distinct fields of practice, it is hoped that students will gain a deeper understanding of the complex national and international forces that shape social work practice in the United States and globally. Students are expected to develop and demonstrate a better understanding of persistent social problems rooted in social, economic, and political inequalities. Courses include those that are required and electives combined with a specialized practicum. Thus, students are expected to develop skills working with groups of marginalized people and advocating for those needs that need to be addressed by larger societies. The program demands are greater than the selective approach but no more than any other concentrated or specialized study.

\section{Integrated Approach}

The integrated approach to internationalizing the social work curriculum has as its goal to prepare significant numbers of social workers for leadership roles in international social work, international social welfare, and international social work development. This approach requires specialized social work educational programs with international social work central to the educational mission. Courses range from an array of interdisciplinary courses and field practicum. Students are expected to develop analytic skills in understanding the complex social, political and economic forces that contribute to global human suffering. The practicum enables students to gain leadership opportunities for 
addressing local, national, and international issues. The resource demands for such an approach are considerable.

Contrasting Similarities and Differences in Strategies Designed for Implementing International Social Work Into Curriculum

The previous section introduced Healy's (2001) and Estes (1992) strategies designed for implementing International Social Work into existing curricula. In this section, I focus on contrasting the similarities and the differences in Healy's (2001) two approaches in Table 8, with an example in Table 9, and Estes' (1992) three approaches which are summarized in Tables 10 through 14 with an example in Table 15 . The tables compare the approaches along the following dimensions: educational purposes, learning objectives, general structure and location of content, and field practice considerations.

\section{Table 8}

Focused and Infusion Approaches

\begin{tabular}{|l|c|c|c|}
\hline Approach & Target Group & \multicolumn{2}{|c|}{ Degree of Comprehensiveness } \\
\hline & & Minimum Essentials & Comprehensive \\
\hline INFUSED & All Students & $\begin{array}{c}\text { Infuse one or more } \\
\text { modules }\end{array}$ & $\begin{array}{c}\text { International- } \\
\text { ization of the } \\
\text { total curriculum }\end{array}$ \\
\hline FOCUSED & $\begin{array}{c}\text { Self-selected } \\
\text { Group }\end{array}$ & $\begin{array}{c}\text { Elective } \\
\text { course }\end{array}$ & $\begin{array}{c}\text { International } \\
\text { concentration }\end{array}$ \\
\hline
\end{tabular}


Table 9

Proposed Curricula Model for Infusion Method (Healy, 2001)

\begin{tabular}{|l|l|}
\hline Diversity & $\begin{array}{l}\text { Emphasizes interlocking and complex nature of } \\
\text { culture and personal identity. } \\
\text { (CSWE, 2002) }\end{array}$ \\
\hline $\begin{array}{l}\text { Populations At Risk/Social and } \\
\text { Economic Justice }\end{array}$ & $\begin{array}{l}\text { Integrate social and economic justice content } \\
\text { grounded in distributive justice, human and civil } \\
\text { rights, and global interconnectedness of } \\
\text { oppression. } \\
\text { (CSWE, 2002) }\end{array}$ \\
\hline $\begin{array}{l}\text { Human Behavior in the Social } \\
\text { Environment }\end{array}$ & $\begin{array}{l}\text { Includes theories and knowledge of biological, } \\
\text { sociological, cultural, psychological, and } \\
\text { spiritual development. (CSWE, 2002) }\end{array}$ \\
\hline Social Welfare Policy and & $\begin{array}{l}\text { Content provides students with knowledge and } \\
\text { skill to analyze local, state, national, and } \\
\text { international issues in social welfare policy and } \\
\text { social service delivery. (CSWE, 2002) }\end{array}$ \\
\hline $\begin{array}{l}\text { Cross-cultural Knowledge and } \\
\text { Skill }\end{array}$ & $\begin{array}{l}\text { Role of culture in shaping human behavior. } \\
\text { Knowledge of cultures other than one's own. } \\
\text { Understanding of the migration of peoples. } \\
\text { Skill in cross-cultural communication. }\end{array}$ \\
\hline Values and Ethics & $\begin{array}{l}\text { Knowledge of different value systems. } \\
\text { Knowledge of major human rights laws and } \\
\text { principles. }\end{array}$ \\
\hline Human Oppression & $\begin{array}{l}\text { Knowledge of selected global problems. } \\
\text { Understanding of the social, political, and } \\
\text { economic impact of global interdependence. } \\
\text { Begin to analyze national social and foreign } \\
\text { policy. }\end{array}$ \\
\hline $\begin{array}{l}\text { Knowledge of major forces of human } \\
\text { oppression. }\end{array}$ \\
\hline
\end{tabular}

The University of Connecticut Center for International Social Work Studies (2004) was established to promote knowledge building and professional competence in International Social Work. A global perspective on social policy and practice interventions is emphasized. This philosophy is placed into practice by (a) encouraging global perspectives and internationally related curricula, (b) 
facilitating faculty research and publication on international issues, (c)

encouraging student and faculty participation in international activities, (d)

promoting cross-cultural competence, and (e) entering into exchanges and

linkage arrangements with schools of social work in other countries and with

international organizations. The university offers a substantive area in

International Issues for students considering careers dealing with international issues (Table10).

Table 10

University of Connecticut Center for International Social Work Studies

(2004)

\begin{tabular}{|l|l|}
\hline Required Courses & $\begin{array}{l}\text { International Social Work } \\
\text { Field Placement }\end{array}$ \\
\hline Two Additional Courses Chosen From: & $\begin{array}{l}\text { Puerto Rican Experience } \\
\text { Urban Policy Issues } \\
\text { Policy Issues and Social Problems of } \\
\text { Women } \\
\text { Family and Children's Services } \\
\text { Services to Immigrants and Refugees } \\
\text { Independent Study } \\
\text { Travel Study in Social Work }\end{array}$ \\
\hline
\end{tabular}


Table 11

Educational Purposes Related With Estes' Alternative Approaches to

Internationalizing Social Work Education

\begin{tabular}{|c|c|c|}
\hline $\begin{array}{l}\text { Selective } \\
\text { Approach }\end{array}$ & $\begin{array}{l}\text { Concentrated } \\
\text { Approach }\end{array}$ & $\begin{array}{l}\text { Integrated } \\
\text { Approach }\end{array}$ \\
\hline $\begin{array}{l}\text { U.S. Students gain a } \\
\text { better understanding of } \\
\text { the international } \\
\text { dimensions of domestic } \\
\text { social problems. } \\
\text { Secondary goal is the } \\
\text { familiarize students with } \\
\text { social work problems } \\
\text { rooted in international } \\
\text { inequalities. } \\
\text { An understanding of } \\
\text { global problems enables } \\
\text { students to intervene } \\
\text { effectively with diverse } \\
\text { populations. }\end{array}$ & $\begin{array}{l}\text { Distinct fields of practice } \\
\text { are identified. } \\
\text { International social work } \\
\text { concentration is } \\
\text { established with the } \\
\text { purpose of students } \\
\text { gaining knowledge, } \\
\text { value, and skill of social } \\
\text { work practice in } \\
\text { international settings. } \\
\text { Focus of concentration is } \\
\text { deeper understanding of } \\
\text { complex national and } \\
\text { international forces that } \\
\text { shape social work } \\
\text { practice. } \\
\text { Students gain skills } \\
\text { working with } \\
\text { marginalized peoples. } \\
\text { Students are expected to } \\
\text { develop skills toward } \\
\text { seeking solutions to } \\
\text { problems based in } \\
\text { political, economic, and } \\
\text { social inequalities. }\end{array}$ & $\begin{array}{l}\text { Goal is to prepare } \\
\text { significant numbers for } \\
\text { leadership roles in } \\
\text { international social work. } \\
\text { Range of interdisciplinary } \\
\text { courses and field } \\
\text { practicum where students } \\
\text { are expected to develop } \\
\text { analytical skills for } \\
\text { understanding the } \\
\text { international social, } \\
\text { political, and economic } \\
\text { forces that sustain global } \\
\text { human suffering. } \\
\text { Practicum expected to } \\
\text { give students leadership } \\
\text { to improving conditions of } \\
\text { oppressed peoples. }\end{array}$ \\
\hline
\end{tabular}


Table 12

Learning Objectives Related With Estes' Three Approaches to

Internationalizing Social Work Education

\begin{tabular}{|c|c|c|}
\hline $\begin{array}{l}\text { Sele } \\
\text { App }\end{array}$ & $A p$ & \\
\hline $\begin{array}{l}\text { Provides for students to } \\
\text { gain a better appreciation } \\
\text { for, and increased } \\
\text { sensitivity, to working } \\
\text { with culturally diverse } \\
\text { population. } \\
\text { Many clients come to } \\
\text { service providers as a } \\
\text { result of international } \\
\text { forces (wars, refugees, } \\
\text { disasters). } \\
\text { Students gain a better } \\
\text { understanding of how } \\
\text { culture, religion, and } \\
\text { ethnicity play a role in } \\
\text { client's lives. } \\
\text { Students expected to } \\
\text { gain knowledge of how } \\
\text { socio-cultural factors } \\
\text { influence effective work } \\
\text { with clients. }\end{array}$ & $\begin{array}{l}\text { Provides students with } \\
\text { opportunities for } \\
\text { examining, } \\
\text { understanding, and } \\
\text { intervening in } \\
\text { international social } \\
\text { events that impact social } \\
\text { work in U.S and globally. } \\
\text { Classes and practicum } \\
\text { allows for development of } \\
\text { skills in working with } \\
\text { others toward } \\
\text { international social work } \\
\text { problems. } \\
\text { Allows for student } \\
\text { development for the } \\
\text { capacity to examine the } \\
\text { dynamics of social policy } \\
\text { across cultures, } \\
\text { assessing those } \\
\text { dynamics, and advancing } \\
\text { programs. }\end{array}$ & $\begin{array}{l}\text { Provides students } \\
\text { extensive opportunities } \\
\text { for examining } \\
\text { international social, } \\
\text { political and economic } \\
\text { forces that cause or } \\
\text { perpetuate international } \\
\text { inequalities. } \\
\text { Skill development for use } \\
\text { in advancing solutions to } \\
\text { international social work } \\
\text { problems. } \\
\text { Strengthens student } \\
\text { capacity for examining } \\
\text { policy across cultures, } \\
\text { assessing dynamics of } \\
\text { those policies, and } \\
\text { advancing programs and } \\
\text { policies. }\end{array}$ \\
\hline
\end{tabular}


Table 13

General Structure and Location of Internationalizing Content in Estes'

\section{Approaches}

\begin{tabular}{|c|c|c|c|}
\hline & $\begin{array}{l}\text { Selective } \\
\text { Approach }\end{array}$ & $\begin{array}{c}\text { Concentrated } \\
\text { Approach }\end{array}$ & $\begin{array}{l}\text { Integrated } \\
\text { Approach }\end{array}$ \\
\hline $\begin{array}{l}\text { General } \\
\text { Structure }\end{array}$ & $\begin{array}{l}\text { International content } \\
\text { infused into existing } \\
\text { courses. } \\
\text { Content competes with } \\
\text { other curriculum } \\
\text { issues. } \\
\text { Open to selected } \\
\text { students. } \\
\end{array}$ & $\begin{array}{l}\text { Concentration in } \\
\text { International Social Work } \\
\text { or International } \\
\text { Social/Economic } \\
\text { Development. } \\
\text { Supported by required } \\
\text { and elective courses and } \\
\text { by practicum. }\end{array}$ & $\begin{array}{l}\text { International content } \\
\text { infused into all learning } \\
\text { experiences. } \\
\text { Selected students for } \\
\text { concentration. } \\
\text { Dual degree programs } \\
\text { may be developed. }\end{array}$ \\
\hline $\begin{array}{l}\text { Required } \\
\text { Courses }\end{array}$ & $\begin{array}{l}\text { International content } \\
\text { infused into existing } \\
\text { courses. }\end{array}$ & $\begin{array}{l}\text { Existing courses are } \\
\text { enhanced by international } \\
\text { content. } \\
\text { Additional required } \\
\text { courses for students with } \\
\text { international } \\
\text { concentration. }\end{array}$ & $\begin{array}{l}\text { A variety of } \\
\text { interdisciplinary } \\
\text { courses. } \\
\text { Elective courses to } \\
\text { include other } \\
\text { disciplines. }\end{array}$ \\
\hline $\begin{array}{l}\text { Elective } \\
\text { Courses }\end{array}$ & $\begin{array}{l}\text { Students encouraged if } \\
\text { courses available. } \\
\text { Electives reach only } \\
\text { small number of } \\
\text { students. }\end{array}$ & $\begin{array}{l}\text { Electives developed to } \\
\text { support specialized } \\
\text { interests. } \\
\text { Students encouraged to } \\
\text { take interdisciplinary } \\
\text { courses. }\end{array}$ & $\begin{array}{l}\text { Variety of } \\
\text { interdisciplinary } \\
\text { courses. } \\
\text { Possibility of courses } \\
\text { from other universities } \\
\text { including those } \\
\text { outside of United } \\
\text { States. }\end{array}$ \\
\hline Thesis & $\begin{array}{l}\text { Research related to } \\
\text { diverse populations. }\end{array}$ & $\begin{array}{l}\text { Documented involvement } \\
\text { in international practice } \\
\text { activity, } \\
\text { Small-scale comparative } \\
\text { analysis of issue of } \\
\text { interest to student. }\end{array}$ & $\begin{array}{l}\text { Documented significant } \\
\text { involvement in } \\
\text { international practice } \\
\text { activity. } \\
\text { Small-scale } \\
\text { comparative analysis of } \\
\text { issue of interest to } \\
\text { student. }\end{array}$ \\
\hline Practicum & $\begin{array}{l}\text { Working with culturally } \\
\text { diverse groups. }\end{array}$ & $\begin{array}{l}\text { Students have } \\
\text { opportunities for } \\
\text { experience locally, } \\
\text { nationally and, outside of } \\
\text { the United States. }\end{array}$ & $\begin{array}{l}\text { Students have } \\
\text { opportunities for } \\
\text { experience locally, } \\
\text { nationally, and outside } \\
\text { of the United States. }\end{array}$ \\
\hline $\begin{array}{l}\text { Foreign } \\
\text { Language } \\
\text { Requirements }\end{array}$ & $\begin{array}{l}\text { Optional, required if } \\
\text { working with non- } \\
\text { English speaking } \\
\text { persons. }\end{array}$ & $\begin{array}{l}\text { Optional, required when } \\
\text { working with non-English } \\
\text { speaking persons. }\end{array}$ & $\begin{array}{l}\text { Required, one } \\
\text { language other than } \\
\text { English. }\end{array}$ \\
\hline $\begin{array}{l}\text { Other Student } \\
\text { Learning } \\
\text { Opportunities }\end{array}$ & $\begin{array}{l}\text { Agency-based } \\
\text { learning. } \\
\text { Join professional } \\
\text { groups. }\end{array}$ & $\begin{array}{l}\text { Participation at national } \\
\text { or international seminars. } \\
\text { Join professional groups. }\end{array}$ & $\begin{array}{l}\text { Participation at national } \\
\text { and international } \\
\text { seminars. } \\
\text { Join professional } \\
\text { groups. } \\
\end{array}$ \\
\hline
\end{tabular}




\section{Table 14}

Field Considerations Associated With Estes'(1992) Alternative Approaches

\section{to Internationalizing Social Work Education}

\begin{tabular}{|c|c|c|c|}
\hline & $\begin{array}{l}\text { Selective } \\
\text { Approach }\end{array}$ & $\begin{array}{l}\text { Concentrated } \\
\text { Approach }\end{array}$ & $\begin{array}{l}\text { Integrated } \\
\text { Approach }\end{array}$ \\
\hline Basic Elements & $\begin{array}{l}\text { Students expected to } \\
\text { develop wide range of } \\
\text { skills. } \\
\text { Performance based on } \\
\text { demonstrated } \\
\text { sensitivity to special } \\
\text { needs of diverse } \\
\text { populations. }\end{array}$ & $\begin{array}{l}\text { Students expected to } \\
\text { develop wide range of } \\
\text { skills working with } \\
\text { individuals and } \\
\text { organizations. } \\
\text { Performance based on } \\
\text { skills and services working } \\
\text { with groups. } \\
\text { Students demonstrate skill } \\
\text { in social planning, } \\
\text { administration, and direct } \\
\text { services }\end{array}$ & $\begin{array}{l}\text { Students expected to } \\
\text { develop wide range of } \\
\text { skills working with } \\
\text { people and } \\
\text { organizations that } \\
\text { reflect cultural and } \\
\text { social diversity. } \\
\text { Focus on skills related } \\
\text { to international } \\
\text { context. }\end{array}$ \\
\hline $\begin{array}{l}\text { Basic } \\
\text { Structure }\end{array}$ & $\begin{array}{l}\text { Flexible; following } \\
\text { classroom learning. }\end{array}$ & $\begin{array}{l}\text { Highly flexible; depending } \\
\text { on student and agency } \\
\text { needs. }\end{array}$ & $\begin{array}{l}\text { Even more flexible } \\
\text { especially with } \\
\text { placements outside of } \\
\text { United States. }\end{array}$ \\
\hline $\begin{array}{l}\text { Types of } \\
\text { Agencies }\end{array}$ & $\begin{array}{l}\text { Established social } \\
\text { service agencies. }\end{array}$ & $\begin{array}{l}\text { Established social service } \\
\text { agencies both in } \\
\text { community and in national } \\
\text { organizations. }\end{array}$ & $\begin{array}{l}\text { Established social } \\
\text { service agencies in } \\
\text { local community, } \\
\text { national and } \\
\text { international } \\
\text { organizations. }\end{array}$ \\
\hline $\begin{array}{l}\text { Range of } \\
\text { Functions }\end{array}$ & $\begin{array}{l}\text { Multiple with emphasis } \\
\text { on direct service }\end{array}$ & $\begin{array}{l}\text { Multiple with emphasis } \\
\text { both in direct service and } \\
\text { involvement in indirect } \\
\text { service that supports } \\
\text { direct service }\end{array}$ & $\begin{array}{l}\text { Multiple but with } \\
\text { emphasis on macro- } \\
\text { level activities. }\end{array}$ \\
\hline Location & Local community & Local and national & $\begin{array}{l}\text { Local, national, and } \\
\text { international }\end{array}$ \\
\hline Supervision & Cooperating agencies & Contractual arrangement & $\begin{array}{l}\text { Special contractual } \\
\text { arrangements }\end{array}$ \\
\hline $\begin{array}{l}\text { Cooperative } \\
\text { Arrangements }\end{array}$ & Usual field setting & $\begin{array}{l}\text { Formal links with } \\
\text { agencies, schools, and } \\
\text { other professional } \\
\text { organizations }\end{array}$ & $\begin{array}{l}\text { Formal linkages } \\
\text { essential with } \\
\text { appropriate } \\
\text { professional agencies, } \\
\text { national and } \\
\text { international } \\
\text { universities. }\end{array}$ \\
\hline
\end{tabular}


Table 15

Proposed Curricula Model for Comparative Social Welfare Research

Education in Estes' (1992) Three Approaches

\begin{tabular}{|c|c|c|}
\hline $\begin{array}{l}\text { Basic Social Research } \\
\text { Methodology }\end{array}$ & $\begin{array}{l}\text { Comparative Social } \\
\text { Welfare Methodology }\end{array}$ & $\begin{array}{l}\text { Supporting Social Science } \\
\text { Elective Content + }\end{array}$ \\
\hline $\begin{array}{l}\text { Introduction to Social } \\
\text { Research }\end{array}$ & $\begin{array}{l}\text { Introduction to Social } \\
\text { Welfare }\end{array}$ & $\begin{array}{l}\text { Sociology-Population } \\
\text { Dynamics Seminar }\end{array}$ \\
\hline $\begin{array}{l}\text { Introduction to Social } \\
\text { Statistics }\end{array}$ & $\begin{array}{l}\text { Methodology of Cross- } \\
\text { cultural research }\end{array}$ & $\begin{array}{l}\text { Macrosocial Theory } \\
\text { Seminar in Comparative } \\
\text { Development }\end{array}$ \\
\hline $\begin{array}{l}\text { Computer-Applications } \\
\text { in Social Sciences } \\
\text { Social Program } \\
\text { Evaluation } \\
\text { Advances Statistical } \\
\text { Methods } \\
\text { Social Research } \\
\text { Practicum } \\
\text { Comparative Welfare } \\
\text { Research Practicum }\end{array}$ & $\begin{array}{l}\text { Comparative Social } \\
\text { Welfare } \\
\text { Comparative Policy } \\
\text { Analysis } \\
\text { Advanced Research } \\
\text { Seminar in } \\
\text { Comparative Social } \\
\text { Welfare } \\
\text { Social Research } \\
\text { Practicum } \\
\text { Comparative Welfare } \\
\text { Research Practicum }\end{array}$ & $\begin{array}{l}\text { Economics- Micro and } \\
\text { Macreconomics, Principles of } \\
\text { International } \\
\text { Economics, Welfare and } \\
\text { International Trade } \\
\\
\text { Political Science- } \\
\text { Comparative Politics, } \\
\text { Comparative Public } \\
\text { Administration, Regional } \\
\text { Studies Seminars } \\
\text { Public Health- Introduction to } \\
\text { International Health, Socio- } \\
\text { cultural Aspects of Health } \\
\text { and Illness, Politics of } \\
\text { International Health } \\
\text { Social Work-Social } \\
\text { Development: Theory and } \\
\text { Practice, Comparative Social } \\
\text { Welfare }\end{array}$ \\
\hline
\end{tabular}

+ Only a partial listing of relevant discipline courses 


\section{Obstacles to Implementation}

Although there is ample research on the need to implement international content into the social work curriculum, researchers agree that there are challenges and obstacles to be overcome. For Horncastle (1994), a major obstacle for the entire social work profession lies in the definition of International Social Work, as social work tasks and responsibilities vary greatly from country to country. The complexities in distinguishing what is international and what is cross-cultural social work has been emphasized (Nagy \& Falk, 2000). They suggested that a 'cross-cultural' perspective include cultural diversity, intercultural communication and cross-cultural understanding. The 'international social work' perspective focuses on social development, social work practice, models and methods in different countries, global social problems, comparative social welfare and policy, and a general world view.

However, global as a social work construct is a challenging concept and it appears to elude Nagy and Falk (2000). "It is useful when talking about social problems or a global perspective but it does not appear to be meaningful to talk about global social work" (p. 55). On the contrary, if the profession is to be a player in assisting to meet the social welfare challenges of globalization, the profession must engage in dialogue focusing on an enhanced perception of global social work. This dialogue must explore the need for a revitalized definition of international social work.

In this dawn of the new millennium and vast strides being made in technology, the basic social work curriculum appears to remain static and 
unchallenged (Davies, 2000). On the university level, (a) resource limitations, (b) an already crowded curriculum, (c) shortages of faculty and expertise, (d) competition from other areas of interest, (e) lack of interest among faculty and students, and ( $f$ ) demanding domestic issues, all serve as obstacles to adding international content to the social work curriculum (Asamoah, 1997; Garland, 1988). Faculty members have many demands on their time and most feel comfortable teaching what they know best. Many have not traveled overseas and feel unprepared to teach from an international perspective. On the other hand, Johnson (1996) found that there is the perception that faculty have a greater interest in international social work when they are older, have had more opportunities to travel, and participated in activities which developed an interest in global issues.

For university social work programs, many issues related to an international practicum remain unsolved. Areas of disagreement include the role of faculty liaison to field supervisors, the preparation of field supervisors, practicum settings, and the objectives of field education (Skolnik, 1999). International practica must encompass more than a field experience of two cultures. Midgely (1990) reminded us that social work is more than just exchanges taking place between different social workers and different cultures. International social work recognizes the interdependence of nations and the need for dialogue and collaboration as we face many global challenges.

Of all accredited graduate schools in the United States, only 1 in 4 has an organizational structure which formally recognizes international social work 
education (Healy, 2001). Of note is Healy's discovery that the education of foreign students and faculty involvement in international research is considered to be international social work by $90 \%$ of the schools.

The transition from interest to commitment is a significant issue in the development of an international social work identity. Thinking globally requires global thinking. However, 15 years since the Estes and Healy studies, the CSWE continues to exhibit preoccupation with domestic practice and only token acknowledgment of the significance of international social work. For example, a review of the Council of Social Work Education $48^{\text {th }}$ Annual Program for 2002 revealed a combined total of 273 paper presentations, symposiums, special presentations, and workshops. Of these, 20 dealt with cultural diversity within the United States and 2 reviewed international applications.

It would seem that at such a point in human history, there should be a course, or at least course content, on international social work. Themes might include, but not be limited to (a) peace and justice, (b) human diversity, (c) human rights, (d) AIDS, (e) cross-cultural awareness, (f) poverty, (g) the environment, (h) comparative social policy, (i) comparative practice models and theory, (j) history and culture as it impacts social work delivery, (I) refugees and border issues, $(m)$ the graying population, and $(n)$ ethnic conflicts. International social work content is not just useful; it is essential.

\section{Need for a New Instrument}

Despite the philosophical focus on including international social work content in social work education, the literature did not reveal enough empirical 
studies to articulate all of the effective strategies for assessing international social work best practices for schools of social work. Hokenstad and Midgley (1997) reported that there is no worldwide data on the number and qualifications of teachers of social work, the number and characteristics of social work students, variations in curricula, and types of practicum. Standards for International Social Work's place within the social work curriculum and its usefulness await further research. It is critical, therefore, that instruments that measure best practices be developed and validated.

\section{Social Work Summary}

This discussion of the literature has confirmed the premise that there is a lack of validated instruments in social work to measure international social work best practices in schools of social work. The literature review of the past two decades of international social work focused on the need for adding International Social Work to social work curriculum content and models for implementation.

\section{Problem Statement Revisited}

The importance of educating social workers who are internationally competent is acknowledged and valued by our profession. However, the quality of international social work curriculum for social workers continues to be challenged. If social workers are not educated to work with an international social work paradigm, there can be profound and unwanted consequences for students, their abilities to engage in social work practice, and for the profession of social work itself (Abbott, 1990; Asamoah, 1997; Barnett, 1991; Bogo \& Herington, 1988; Broadfoot, 2000; Davies, 2000; Goldstein, 1986; Nagy \& Falk, 2000). The 
need for understanding and developing different models for teaching international social work has emerged and strategies of implementing into the social work curriculum have been proposed (which have been discussed in this chapter). In spite of the awareness and importance being placed on international social work content, not many studies have been conducted to evaluate the best practices of international social work education.

\section{InCon Approach}

I propose the InCon approach for implementing an International Social Work Best Practices curriculum for schools of social work. I have incorporated CSWE's 2002 Educational Policy and Accreditation Standards as well as major components of Este's (1992) concentrated approach and Healy's (2001) infused approach best practices into the InCon Approach. I chose the InCon approach for it allows all social work students to be exposed to International Social Work either through infusing through existing courses or to specialize and concentrate in this particular area of social work, thus dealing with several issues concerning obstacles to implementation. This approach uses a two-pronged, not an either or, approach to International Social Work Best Practices Curriculum for schools of social work: Infusion and Concentrated. The InCon approach is based on the integration of: (a) diversity, (b) populations at risk/ social and economic justice,

(c) human behavior in the social environment, (d) social welfare policy and services, (e) cross-cultural knowledge and skill, (f) values and ethics, (g) social policy and problems, and (h) human oppression into both an infused and specialized curriculum. 


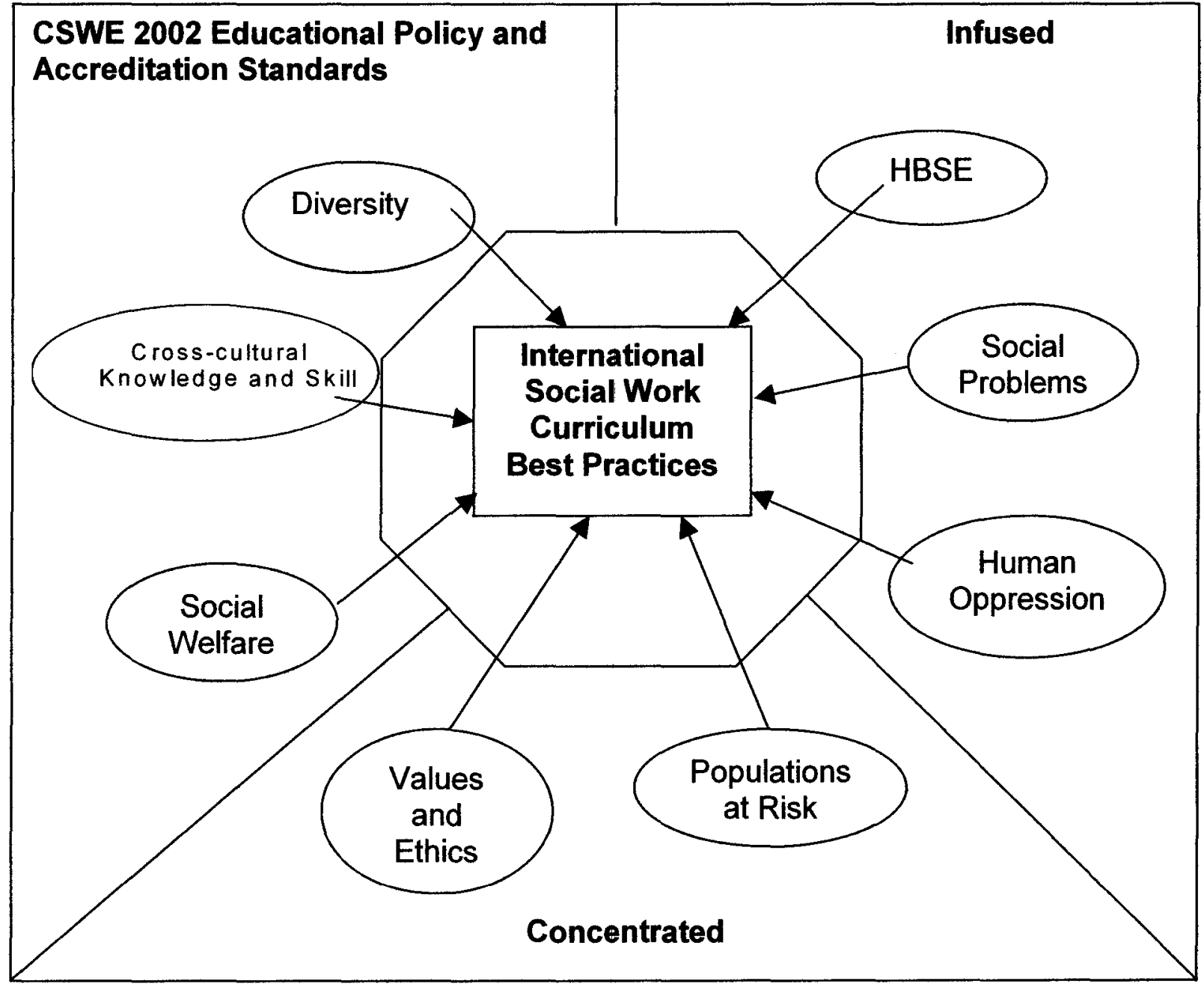

Figure 2. InCon approach for developing international social work curriculum best practices. 
Table 16

Curriculum Strategy Using the InCon Approach

\begin{tabular}{|c|c|c|}
\hline & Infused Tract & Concentrated Tract \\
\hline General Structure & $\begin{array}{l}\text { International content } \\
\text { infused into existing } \\
\text { courses. Open to all } \\
\text { social work students. }\end{array}$ & $\begin{array}{l}\text { Concentration in } \\
\text { International Social Work } \\
\text { with both required and } \\
\text { elective courses. }\end{array}$ \\
\hline Required Courses & $\begin{array}{l}\text { International content } \\
\text { infused into existing } \\
\text { required courses with } \\
\text { links to the eight areas } \\
\text { emphasized by } 2002 \\
\text { EPAS. }\end{array}$ & $\begin{array}{c}\text { Seminar in International } \\
\text { Issues (2 semesters) } \\
\text { Social Policy } \\
\text { Practicum }\end{array}$ \\
\hline Elective Courses & $\begin{array}{l}\text { Students encouraged } \\
\text { taking. }\end{array}$ & $\begin{array}{c}\text { Select Two: } \\
\text { Populations at Risk } \\
\text { Policy Issues and the } \\
\text { Social Problems of } \\
\text { Women } \\
\text { Global Interdependence } \\
\text { Ethnic Conflict and } \\
\text { Refugees } \\
\text { Global Graying } \\
\text { International Social Work } \\
\text { as a Profession } \\
\text { Independent Study }\end{array}$ \\
\hline Thesis & Topic in Social Work & $\begin{array}{c}\text { Research related to } \\
\text { International Social Work }\end{array}$ \\
\hline
\end{tabular}

\section{Educational Policy and Accreditation Standards}

The 2002 Council on Social Work Education's Educational Policy and Accreditation Standards (EPAS) for International Social Work Curriculum implies

(a) an emphasis on impact of culture in the Human Behavior and Social 
Environment and Practice classes, (b) rethinking approaches to social policy to emphasize international issues, not comparative social welfare, (c) addressing international forces of oppression in approaches to content on social and economic justice, and (d) including human rights content into the social work curriculum.

Within the preamble, it states "social work practice promotes human wellbeing by strengthening opportunities, resource, and capacities of people in their environments and by creating policies and services to correct conditions that limit human rights and the quality of life. Guided by a person-in-environment perspective and respect for human diversity, the profession works to effect social and economic justice worldwide" (p. 3).

\section{Diversity}

The 2002 EPAS stressed the interlocking and complex nature of culture and personal identity. By placing diversity within a foundational content, it ensures that social services meets the needs of groups served and are culturally relevant. As stated in the EPAS, social work education aims to prepare social workers to practice without discrimination, with respect to, and with knowledge and skills related to clients' age, class, color, culture, disability, ethnicity, family structure, gender, marital status, national origin, race, religion, sex, and sexual orientation; recognizing the global context of social work practice; and preparing social workers to formulate and influence social policies and social work services in diverse political contexts" (CSWE, 2002). 


\section{Populations at Risk/Social and Economic Justice}

The 2002 EPAS calls for programs to integrate social and economic justice content must be grounded in an understanding of distributive justice, human and civil rights, and the global interconnection of oppression.

\section{Human Behavior in the Social Environment}

The 2002 EPAS states that curriculum content must include theories and knowledge of biological, sociological, cultural, psychological, and spiritual development across the lifespan. "Guided by a person-in-environment perspective and respect for human diversity, the profession works to effect social and economic justice worldwide" (CSWE, 2002, p 11).

\section{Social Welfare Policy and Services}

Course content is required that provides students with the knowledge and skills to analyze organizational, local, state, national, and international issues in social welfare policy and social service delivery.

\section{Cross-Cultural Knowledge and Skill}

The 2002 EPAS stresses acquiring (a) knowledge of the role of culture in shaping human behavior, (b) knowledge of cultures other than one's own and principles for learning about other cultures, (c) understanding the process and impact of voluntary and involuntary migration of people, and (d) practice skill in cross-cultural communication.

\section{Values and Ethics}

The EPAS requires that students have (a) introductory knowledge of different value systems, especially individual vs. communal orientations, (b) 
familiarity with the universalism-cultural relativism debate within ethics and human rights and the relevance of that debate to practice, and (c) knowledge of major human rights laws and principles.

\section{Social Policies and Problems}

The EPAS requires that students have (a) knowledge of selected global social problems-especially those with local manifestations, (b) understanding of the global, political, and economic impact of global interdependence, (c) the beginning ability to identify, analyze, and influence national social and foreign policies that affect people in and from other nations, and (d) knowledge of the major world and regional instruments of human rights machinery and law and the local applications.

\section{Human Oppression}

EPAS points to the importance of students acquiring knowledge of the major forces of human oppression internationally and the interconnections of these major forces. The suggested strategy is to link lessons on social issues, such as immigration and AIDS. Either issue can be expanded to include dimensions of race, economic oppression, and poverty.

\section{Optimal Outcomes for the InCon Approach to International Social Work}

\section{Curriculum Best Practices}

Using the InCon approach to International Social Work Curriculum Best Practices should allow for optimal outcomes on (a) familiarity with history of social work around the world, (b) knowledge of the ways the profession is organized for international action, (c) knowledge of major agencies involved in 
international social work, (d) awareness of global interdependence and its affect on social issues, (e) understanding migration and sensitivity to cultural diversity, (f) awareness of the impact of U.S. policy on other countries, (g) sensitivity to value dilemmas in international social work, $(h)$ knowledge of global human rights standards, and (i) ability to analyze global social policy and appropriate advocacy.

\section{InCon Teaching Strategies}

A couple of teaching strategies may assist in using the InCon approach to International Social Work Curriculum Best Practices: (a) using video and the internet to introduce students to global conditions or to introduce international issues, (b) using distance education and web-based technology to enhance learning, such as direct links to students and faculty from other countries, and (c) using speakers and authors of articles from other countries to introduce alternative perspectives.

\section{Conclusion}

Social work values, reasons for international studies curriculum, strategies for implementing social work education, and obstacles to implementation were presented in this chapter. A detailed review of the literature was presented and followed by a proposed model for understanding International Social Work Curriculum Best Practices. In the next chapter, the research methodologies used in this study are presented. 


\section{CHAPTER 3}

\section{METHODOLOGY}

In this chapter, the manner in which this study was conducted will be described. The research design is a blue-print (Rubin \& Babbie, 2001) that helped plan the research and sampling design, identify and operationalize key variables, and propose procedures for collecting and analyzing data.

\section{Overview of the Study}

The aim of this research was to assess the current status quo of International Social Work teaching practices in CSWE accredited MSW programs of social work. Three major objectives supported the purpose and aim of this research.

The first objective was to identify the key areas of International Social Work teaching practices based on the 2002 CSWE Educational Policy and Accreditation Standard and synthesis of the literature of theories and models of teaching international social work. The second objective was to assess the current status quo of International Social Work teaching practices in CSWE accredited MSW programs of Social Work. The final objective was to define anchor points for unacceptable, essential, and exemplary teaching practices based on respondent answers to the survey. 


\section{Research Design}

A multimethod approach was utilized, a combination of both qualitative and quantitative research methods (Padgett, 1998) to achieve the three objectives of this research. To achieve the first objective, a content analysis was conducted on the CSWE 2002 Educational Policy and Accreditation Standards and research pertaining to models and theories of teaching international social work. Content analysis is a method of quantitatively analyzing qualitative data. and consists of coding and tabulating the occurrences of certain content that are being communicated (Rubin \& Babbie, 1997). To accomplish the second objective, a quantitative and qualitative research design was employed. I developed a survey to assess the current status quo of International Social Work teaching practices in CSWE accredited MSW programs of Social Work. To achieve the third objective, respondents' answers were utilized to assess anchor points for unacceptable, essential, and exemplary practices. In the following sections, I discuss the different methodological processes that were utilized to achieve these objectives.

\section{Objective 1: Content Analysis and Synthesis of the Literature}

A content analysis was used to analyze the CSWE 2002 Educational Policy and Accreditation Standards by using the open coding method. Open coding is the part of analysis that pertains specifically to categorizing and naming communication through close examination of the data and finds its roots in grounded theory. Open coding involves breaking the data down into discrete parts, closely examining those parts, comparing similarities and differences, and 
asking questions about the phenomena as reflected by the data (DeVos, 1998).

The steps include (a) labeling the phenomena, (b) discovering categories, (c) naming categories, and (d) developing categories in terms of properties and dimensions.

After the key areas were identified, the literature was synthesized to identify various and current models and teaching practices drawn upon to present international social work within the social work curriculum. Key areas were defined to create a better understanding of what unacceptable, essential, and exemplary practice are in international social work best practices curriculum. The following steps were taken: (a) obtaining a sense of the whole, (b) identifying themes, (c) making a list of topics, (d) organizing literature into topics, and (e) grouping related topics (Horne, 1999). The final product of this synthesis was the operational definitions of each of the key areas.

\section{Objectives 2 \& 3: Current Status Quo of International Social Work Teaching Practices and Criteria for Anchor Points}

Exploratory research seeks to accomplish the following: (a) examine a subject that is relatively new, (b) discover new explanations, (c) focus on research questions, and (d) use both quantitative and qualitative methods. Nonprobability sampling is used almost exclusively to gain insights from the people in the sample and findings are not intended to be generalized (Dudley, 2005; Ginsberg, 2001; Rubin \& Babbie, 2001). In order to understand the current status quo of International Social Work teaching practices curriculum in the United States and Puerto Rico, the developed survey was placed on the Internet. 
The data were analyzed with basic descriptive statistics to show the current status quo of International Social Work teaching practices.

Respondents'qualitative answers were utilized to determine the criteria for anchor points for unacceptable, essential, and exemplary practice.

\section{Research Design}

The research design for the survey was based on Dillman's (2000) Tailored Design Theory. Dillman's method responds in particular to the possibilities now offered by computer publishing possibilities and is presented in Table 17. Tailored Design consists of two parts: (a) identify each aspect of the survey process that seems to affect either quality or quantity response, and (b) organize the survey efforts so that design intentions are in complete detail. Designing a survey begins with two assumptions: (a) responding to the survey requires not only cognition but also motivation and, (b) multiple attempts to contact respondents are essential. Thus, it is a set of procedures for conducting successful self-administered surveys that produce both high quality information and response rates. The procedures are developed to increase rewards and reduce costs and the overall goal is the reduction in survey error with special emphasis on nonresponse and measurement error. The distinguishing feature of Tailored Design is that rather than relying on one basic procedure for all survey situations, it builds on social exchange theory through knowledge of the population surveyed and sponsorship. Social Exchange Theory is used to explain the development and continuation of human interaction. Three elements are critical within this theory: rewards, costs, and trust. Rewards are what one 
expects to gain from any given activity. Costs are what one gives up or spends to obtain the rewards. Trust is the expectation that in the long run, the rewards of doing something will outweigh the costs. People are more likely to respond and complete a questionnaire if the trust that the rewards of doing so outweigh the costs (Dillman 2000).

Table 17

Tailored Design

\begin{tabular}{|c|c|}
\hline \multicolumn{2}{|c|}{ Elements } \\
\hline $\begin{array}{l}\text { Identify aspects of survey process } \\
\text { likely to affect either quality or } \\
\text { quantity of response. }\end{array}$ & $\begin{array}{l}\text { Organize the survey so that } \\
\text { design intentions are carried } \\
\text { out in complete detail. }\end{array}$ \\
\hline \multicolumn{2}{|l|}{ Goals } \\
\hline $\begin{array}{l}\text { Reduce Survey Error } \\
\text { Sampling Error } \\
\text { Coverage Error } \\
\text { Measurement Error } \\
\text { Nonresponse Error }\end{array}$ & $\begin{array}{l}\text { Increase Response Rates } \\
\text { Rewards } \\
\text { Costs } \\
\text { Trust }\end{array}$ \\
\hline \multicolumn{2}{|c|}{ Assumptions for Designing Surveys } \\
\hline $\begin{array}{l}\text { Responding to a self-administered } \\
\text { survey involves cognition and } \\
\text { motivation }\end{array}$ & $\begin{array}{l}\text { Multiple attempts are } \\
\text { essential to achieving } \\
\text { satisfactory response rates }\end{array}$ \\
\hline \multicolumn{2}{|c|}{ Ways of Providing Rewards } \\
\hline $\begin{array}{l}\text { Show positive regard } \\
\text { Support group values }\end{array}$ & $\begin{array}{l}\text { Seek respondent advice } \\
\text { ire interesting }\end{array}$ \\
\hline \multicolumn{2}{|c|}{ Ways of Reducing Costs } \\
\hline $\begin{array}{l}\text { Avoid subordinating language } \\
\text { Avoid inconvenience } \\
\text { Make questionnaire appear short and easy }\end{array}$ & $\begin{array}{l}\text { Avoid embarrassment } \\
\text { Minimize request for } \\
\text { personal info }\end{array}$ \\
\hline \multicolumn{2}{|c|}{ Ways of Establishing Trust } \\
\hline $\begin{array}{l}\text { Provide token of appreciation } \\
\text { Make task seem important }\end{array}$ & $\begin{array}{l}\text { Sponsored by legitimate } \\
\text { authority and invoke other } \\
\text { exchange relationship }\end{array}$ \\
\hline \multicolumn{2}{|c|}{ Underlying Theory } \\
\hline Theory: $\mathrm{Th}$ & ifr \\
\hline
\end{tabular}


Dillman (2000) offered four ways of providing rewards: (a) providing a cover letter with reasons why the survey is being done and by providing a phone number by which a respondent can contact the investigator, (b) provide a way of saying "thank you", (c) asking respondents for advice, and (d) making the questionnaire interesting. Reducing costs for the respondent included avoiding subordinating language, embarrassment, unneccessary inconvenience, making the questionnaire appear short and easy, and minimizing the need for personal information. Establishing trust included a token of appreciation, showing that the survey is sponsored by a legitimate authority, and making the task seem important. The major goal of Tailored Design is to reduce four types of survey error. The first is sampling error, which occurs when only some but not all of the population is surveyed. The second type of error is coverage error, which occurs when the list from which the population is drawn does not include the total population. Measurement error is the third type of error that occurs when a respondent's answers are inaccurate, incomplete, or cannot be compared with other respondents' answers. The fourth error, nonresponse error, occurs when significant numbers of people in the survey sample do not respond (Dillman 2000). Dillman (2000) suggests elements for achieving a high response rate: a) respondent friendly questionnaire, (b) cover letter and thank you response, and (c) the questionnaire.

For this survey, both sampling error and coverage error was kept to a minimum when the entire population was invited to be a part of this survey. The CSWE website was utilized to get an updated list of all masters programs and 
those within candidacy of CSWE accredited schools of social work. With regards to nonresponse error, a respondent friendly survey was created with a cover letter explaining the purpose of the survey and the importance of responding. The last group of respondents did not offer a specific course in international social work but infused international content into already existing courses. This last group rated the infusion and gave reasons for their ratings. An automatic thank you response was sent via email to all those who took part in the survey. PHP Surveyor and SPSS were used to analyze responses in order to minimize measurement error.

When designing Internet survey questions, there are questions to be considered in the beginning of the process: Whom are you surveying? What is the topic? How many contacts do you plan to make? What interval will you use between contacts? How long is the questionnaire to be? Dillman's Tailored Design suggests specific design principles for web-based surveys;

1. Introduce with a welcome screen that is motivational and emphasizes ease in responding with instructions on how to proceed to the next page.

2. Provide tokens for limiting access to only the people in the sample.

3. Choose a first question that is easily answered.

4. Present each question in a conventional format (begin with a number or if there are answers, indent.

5. Refrain from overuse of color.

6. Avoid differences in visual appearance of the questions.

7. Provide specific instructions. 
8. Use drop down responses sparingly.

9. Do not require respondents to answer every question.

10. Provide skip questions.

11. Construct the survey so that respondents can scroll from question to question.

12. Do not use "check all that apply" question structure.

For the purpose of this survey, PHP Surveyor was used to create the webbased survey. The survey was introduced with a welcome screen that emphasized the ease of completing the survey, was motivational in explaining the importance of this research, and provided instructions with how to proceed. Individual tokens were provided that limited access to only those who received an email invitation to participate. The first question was one that was easily answered to encourage further participation.

The format of the survey included three distinct sections: demographic information, format of international social work curriculum, and infusion of international social work content. Each question began with a number, answers were indented, and differences in visual appearance were limited. The use of color was not overused and drop down responses were used sparingly. Specific instructions were provided for each section. Questions were formatted so that respondents could skip questions that were not applicable to them and were not required to answer each individual question. Respondents were able to scroll from question to question and move within the format of the survey. There were no questions that used the "check all that apply" structure. 
There are advantages and challenges to web based surveys. Advantages include: (a) questions are constructed in a fixed format that appears the same for all respondents, (c) a sense of progress can be created to avoid people quitting in the middle of the survey, (c) additional features can be added to entice people to respond, and (d) the ease of having statistical data electronically stored for analyzing (Babbie, 2004; DeVos, 1998; Dillman, 2000; Singleton \& Straits, 1999).

In regards to this survey, the format was fixed so that it appeared the same for all respondents. With the format of three sections, a sense of progress was created to avoid respondents quitting in the middle of the survey. Additional features were added to entice people to respond. Quantitative rating questions were followed by qualitative questions allowing respondents to provide reasons for their ratings.

The challenges of web based surveys include: (a) the use of open-ended questions where the answer depends on the extent to which the respondents are willing to think hard and write complete sentences and (b) minimizing all four types of potential sample error (Dillman, 2000; Rubin \& Babbie,1997). An inability to get adequate answers to open-ended questions is often identified as the major disadvantage to surveys. The usefulness of open-ended questions depends on the way in which they are structured. Reliability refers to whether a survey applied repeatedly would yield the same response. Validity refers to the confidence that the results of a survey accurately depict and can be generalized beyond the study conditions. The challenges listed above were also challenges 
for this survey. The use of open-ended questions did depend on the respondent's willingness to provide complete information.

\section{Data Collection Tool}

The survey (Appendix A) was comprised of three sections seeking to ascertain the current status of international social work within the social work curriculum: (a) demographic information, (b) format of international social work content within curriculum and (c) infusion of international social work content. The demographic section was comprised of seven questions asking for a description of the university/college: type of university/college, number of students enrolled, setting of the university, number of students enrolled in the social work program, type of social work degrees offered, number of full-time tenure track faculty in the social work program, and the number of full-time faculty with an interest in international social work.

The format section of the survey asked if international social work is covered within the social work curriculum and if it is, how international social work is presented within the social work curriculum. Respondents were asked to rate the quality of the format for their program and then to provide reasons for their rating. Sample questions asked if international social work is offered as a core course, as an elective with a field trip, as an elective without a field trip, as a specialized tract, as an overseas practicum, or is infused into the present curriculum. Rating how technology was used to enhance the curriculum was also researched. 
The final section of the survey focused on infusing international social work into existing social work courses. Using CSWE's EPAS 2002, eight topic included (a) diversity, (b) populations at risk/social and economic justice, (c) human behavior in the social environment, (d) social welfare policy and services, (e) cross-cultural knowledge and skill, (f) values and ethics, (g) social problems, and (h) human oppression. Respondents were asked to rate the quality of infusion and then to provide reasons for their rating.

\section{Sampling Design}

Using purposive sampling to gain insights into the attributes of effective practice, the participation of all CSWE accredited schools of social work $(n=190)$ were solicited by sending letters/e-mails to the dean/directors who were listed in the online CSWE directory of the Graduate Social Work Programs in Spring 2005. This list of accredited programs of social work is updated yearly by CSWE.

The unit of analysis was graduate level social work curricula in CSWE accredited institutions. All of the identified schools were invited to participate in the study. The developed instrument was posted on the World Wide Web for ready access.

\section{Recruitment of the Sample}

Letters were mailed in October 2005 inviting deans and directors for their participation from all of the 190 CSWE accredited U.S. Schools of Social Work that have masters' programs or were in candidacy. Four deans/directors were unable to participate in the survey. Two of the colleges/universities were closed 
due to the effects of Hurricane Katrina in Louisiana. Two deans were sent letters through the mail and two follow up phone calls were placed in order to obtain email addresses. Neither the written letters nor the phone calls generated replies. The survey was put online in October 2005. A total of seven contacts were made with the population sample. After the initial invitation was sent on October $20^{\text {th }}$, every two weeks an e-mail reminder was sent to the deans/directors who had not replied in the first round of the data collection. The reminders brought an average of 6-8 additional responses each time. The final responses totaled 91 out of 186 or a $49 \%$ response rate. With a population of 186, responses from 91 , I have a $90 \%$ confidence level with $6.2 \%$ error that if I was to conduct this survey 100 times, the results would be within $+/-6.2 \%$ of the first time that the survey was run.

\section{PHP Surveyor}

PHPSurveyor is an Internet based program that was used to place the Current Status of International Social Work Curriculum survey online. The program is a multi-question surveying tool that allows for the development of surveys. The PHP surveyor was easily adaptable to fulfill the requirements of the research design using Dillman's Tailored Design. When surveys are completed, the software automatically saves the data into a database. The data can then be transferred to other software packages for analysis or can be summarized with PHPSurveyor using pre-configured statistical templates to summarize results in charts, graphs, or other formats. For this study, the data were transferred into SPSS for analysis. 


\section{Issues of Confidentiality/Informed Consent}

The Human Studies Committees at the University of Louisville approved the study. Deans or directors were introduced to the research and invited to participate. The respondents were informed at the start that their participation in this study would help researchers define International Social Work curriculum best practices and develop instruments to measure it. The entire process was anonymous and concrete steps were taken to ensure respondents' privacy.

\section{Benefits and Risks}

The benefits of this study included (a) contributing to the literature on International Social Work curriculum best practices, and (b) development of descriptive anchor points that can identify unacceptable, acceptable, and exemplary best practices in International Social Work. This study posed no risk or unforeseen threats to respondents.

\section{Conclusion}

In this chapter, the purpose of the study and the three major objectives were identified. The process for understanding the current status quo of International Social Work teaching practices and the data tool were presented. In the following chapter, results will be presented followed by discussion and implications of the results for international social work best practices in the final chapter. 


\section{CHAPTER 4}

\section{RESULTS}

In this chapter, the results of the study will be discussed in detail. In the first section, I provide demographic information of the sample. In the next two sections, I provide the results of the statistical analyses conducted to answer the two research questions:

1. What is the current status of International Social Work teaching practices in CSWE accredited MSW programs of Social Work?

2. How can these components be measured to differentiate between unacceptable, essential, and exemplary practice? (Huber, Borders, Badrak, Netting, \& Nelson, 2001)?

\section{Demographics of the Respondents}

The total survey population consisted of 186 deans or directors of CSWE accredited MSW programs or those in candidacy. Ninety-one deans/directors out of 186 responded to the survey. The demographics of the 91 respondents are described in this section.

The respondents were asked to categorize their universities as public or private. Three quarters of the deans/directors that responded came from public universities $(n=69)$. Twenty three percent $(n=21)$ came from private universities and one respondent did not reply to this question (Table 18). This sample, when compared to national data on CSWE accredited Masters Degree 
Programs, consists of an overrepresentation of private universities. Only $18 \%$ of MSSW accredited schools are private. The results should be interpreted taking this overrepresentation into account.

\section{Table 18}

\section{Descriptive Characteristics-Type of University}

\begin{tabular}{|l|c|c|}
\hline $\begin{array}{l}\text { Type of } \\
\text { University }\end{array}$ & $\mathbf{n}$ & $\%$ \\
\hline Public & 69 & $77 \%$ \\
Private & 21 & $23 \%$ \\
Total & 90 & $100 \%$ \\
\hline
\end{tabular}

The respondents were asked to provide statistical information regarding the number of students enrolled in their universities and also enrolled in the schools or departments of social work. The number of students enrolled in the universities ranged from 200 to 80,000 . The mean number of students enrolled was $19,877(S D=14880)$. The median was 16,000 and the mode 35,000 . Bigger and larger universities were equally represented in this sample. Six respondents chose not to answer (6.6\%). The same can be said about representation of different size of schools of social work. The number of students enrolled in schools of social work ranged from 27 to 1009 . Schools with between 300 and 415 students were slightly more than other size schools. The mean was $342(S D=200.42)$, the median was 331.08 , and the mode 300 students. One respondent did not answer this question.

Respondents were asked which degrees were offered in their social work programs (Table 19). One hundred percent of the programs that responded to the survey offered a master's degree program. Nearly three quarters of those 
responding $(n=67)$ offered a BSW program. Of those responding $(n=35), 38.5$ $\%$ offered doctoral programs.

\section{Table 19}

Descriptive Characteristics-Degree Programs Offered

\begin{tabular}{|l|c|r|}
\hline $\begin{array}{l}\text { Degree } \\
\text { Offered }\end{array}$ & $\mathbf{n}$ & \multicolumn{1}{c|}{$\%$} \\
\hline BSW & 67 & 73.6 \\
MSW & 91 & 100.0 \\
PhD & 35 & 38.5 \\
\hline
\end{tabular}

Table 20 shows at the settings for the colleges and universities.

Respondents were asked to define their college setting as rural, suburban, or urban. Over half of the respondents $(n=54)$ classified their university setting as urban. Twenty-one percent classified their college setting as suburban $(n=18)$ and $16 \%$ rural $(n=14)$. Five respondents did not answer this question.

\section{Table 20}

\section{Descriptive Characteristics-College/University Setting}

\begin{tabular}{|l|c|r|}
\hline $\begin{array}{l}\text { College/University } \\
\text { Setting }\end{array}$ & $\mathbf{n}$ & $\%$ \\
\hline Rural & 14 & 16.3 \\
Suburban & 18 & 20.9 \\
Urban & 54 & 62.8 \\
Total & 86 & 100.0 \\
\hline
\end{tabular}

When looking at type of university and university setting of those who responded (Table 21), 58\% are public universities in urban settings. Eighteen percent are public universities in suburban settings and 15\% are public universities in rural settings. The largest percentage of private universities 
identified as located in urban settings (18\%). Six respondents chose not to answer this question.

\section{Table 21}

\section{Descriptive Characteristics-Type of College/University and Setting}

\begin{tabular}{|lrrr|}
\hline \multicolumn{4}{|c|}{ College/University Type and Setting } \\
\hline & Rural & Suburban & Urban \\
Public & $13(15.3 \%)$ & $15(17.6 \%)$ & $38(57.6 \%)$ \\
Private & $1(1.2 \%)$ & $3(3.6 \%)$ & $15(17.6 \%)$ \\
\hline
\end{tabular}

Respondents were asked to provide statistical information regarding the number of full time tenured track faculty at the colleges/universities in the social work programs. The number of full time tenured faculty in social work programs ranged from 2 to 54 . The mean was $16.13(S D=9.37)$ and the median 15 . Multiple modes existed. Two respondents chose not to answer.

Respondents were then asked to provide the number of tenured track faculty with an interest in international social work in their social work programs. Nearly three quarters of those who responded (73. \%) had from 1 to 5 faculty members with an interest in international social work. The number of faculty with an interest in international social work ranged from 1 to 40 with the mean 5.47 $(S D=5.46)$ and the median 4.00. Multiple modes existed. Two chose not to respond.

\section{Format of International Social Work Curriculum}

In this section the respondents were asked if and how international social work is found within the social work curriculum. Respondents were then asked to rate the quality of the international social work content in their social work 
curriculum on a scale of $1-7$ Likert scale. Unacceptable ranged from 1 - 2 , acceptable from $3-5$, and exemplary from $6-7$. Respondents were then offered the opportunity to give their reasons for their ratings.

\section{Format: International Social Work Infused Or Offered As Specific Course}

Table 22 looks at whether international social work is infused into existing social work classes or is offered as a specific course. Over three quarters of those who responded affirmed that their programs offered international social work that is either infused into existing courses or offered as a specific course. Of those who responded, $78 \%$ rated their international social work content in the acceptable range. Less than $6 \%$ of those who responded rated their international social work content as unacceptable. Eleven respondents (16\%) rated their international social work content as exemplary. Three respondents did not rate the international social work content.

Forty-two respondents provided reasons for their ratings. $100 \%$ of those who rated their program as unacceptable provided reasons. Eight of those who rated their international social work as exemplary provided reasons for their ratings. Of those who rated their international social work as acceptable, 35 provided reasons for their ratings. Two respondents chose not to rate the quality of their international social work content. 
Table 22

Format: International Social Work Infused or Offered as Specific Course

\begin{tabular}{|c|c|c|}
\hline & $\mathrm{n}$ & $\%$ \\
\hline Yes & 71 & 81.6 \\
\hline No & 16 & 18.4 \\
\hline Total & 87 & 100.0 \\
\hline
\end{tabular}

Rate Quality of International Social Work Content

\begin{tabular}{|c|c|c|}
\hline Unacceptable & Acceptable & Exemplary \\
\hline 4 & 53 & 11 \\
\hline
\end{tabular}

\section{Reasons for Rating}

\begin{tabular}{|c|c|c|}
\hline $\begin{array}{l}\text { Infusion across } \\
\text { curriculum areas not as } \\
\text { complete as it should be and } \\
\text { dependent upon individual } \\
\text { faculty members } \\
\text { international social work within } \\
\text { the curriculum } \\
\text { work limited to one elective } \\
\text { with lack of other specific } \\
\text { courses } \\
\text { work offered but at a minimal } \\
\text { level within policy courses } \\
\text { work does not command } \\
\text { interest or attention of } \\
\text { ctudontc }\end{array}$ & $\begin{array}{l}\text { - Excellent elective } \\
\text { offerings including } \\
\text { specialization } \\
\text { course on international social } \\
\text { work A specific course is } \\
\text { - } \quad \text { Offering a formal } \\
\text { offer and comparative } \\
\text { content cuts across all courses } \\
\text { so that all students are } \\
\text { exposed to international social } \\
\text { work } \quad \text { Faculty teaching } \\
\text { international content are } \\
\text { excellent and highly committed } \\
\text { - An increasing number } \\
\text { of international students } \\
\text { - Collaborative work } \\
\text { with other countries } \\
\text { - Integrated classroom } \\
\text { content with study abroad } \\
\text { opportunities } \\
\text { r Hiring of faculty with } \\
\text { reputation in international } \\
\text { research and program } \\
\text { development with possibility of } \\
\text { opening a campus in China } \\
\end{array}$ & $\begin{array}{l}\text { - International content is } \\
\text { constantly being reviewed and } \\
\text { updated } \\
\text { - } \quad \text { Faculty members with } \\
\text { expertise combined with } \\
\text { students studying abroad and } \\
\text { some faculty exchange. } \\
\text { - Doctoral program } \\
\text { offered in collaboration with a } \\
\text { Mexican university } \\
\text { - International content } \\
\text { entitled "Globally Focused and } \\
\text { Family Centered" with dean } \\
\text { who has a vision that included } \\
\text { global content across the } \\
\text { curriculum }\end{array}$ \\
\hline
\end{tabular}




\section{Format: International Social Work Not Currently A Component of Social}

\section{Work Curriculum Content But Is In Process}

Respondents were asked, if international social work was not currently a component of the social work content, was international social work in the process of being included in the social work content (Table 23). Eight respondents reported that at this time international social work was not a component of social work content but was in the process of being included. The respondents were then asked how international social work could be included in the social work curriculum. All eight who responded (100\%) provided explanations as to how international social work could be included in the social work curriculum. Seventy-one respondents already had international social work as part of their social work curriculum and were not supposed to answer this question.

Table 23

Format: ISW Not Currently a Component of SW Content But in Process Frequency

\begin{tabular}{|c|c|c|}
\hline & $n$ & $\%$ \\
\hline Yes & 8 & 46.7 \\
\hline No & 7 & 53.3 \\
\hline Total & 15 & 100.0 \\
\hline
\end{tabular}

\section{How International Social Work Is Being Included}

One college reported that a faculty member was granted a sabbatical to develop international social work curriculum with the sabbatical to begin in the spring of 2007. Another university stated that a major review and revision of the social work curriculum was underway across all sequences to identify 
where international content could be included. Other universities reported that the faculty was in the process of incorporating international social work content into existing courses. A concentration in international social work has been proposed and in the planning stage for another social work program. One program stated that an elective with an experiential component has been proposed geared toward MSW and non-traditional student and is awaiting department chair approval.

\section{Format: International Social Work Offered As Core Course Within Specialization}

Table 24 shows whether international social work is offered as a core course within the social work curriculum. Twenty-seven percent of those who responded answered that international social work is offered as a core course while $73 \%$ responded that international social work is not offered as a core course.

Eighteen of the respondents who answered yes provided ratings. No respondents rated the international social work core course as unacceptable. Sixty-one percent of those who responded rated their international social work core course as exemplary. The respondents were then asked to give reasons for rating the core course as they did (Table 24). 
Table 24

Format: International Social Work Offered as Core Course Within

Specialization

\begin{tabular}{|c|c|c|}
\hline & $n$ & $\%$ \\
\hline Yes & 19 & 27.1 \\
\hline No & 52 & 72.9 \\
\hline Total & 71 & 100.0 \\
\hline
\end{tabular}

\section{Rate Quality of International Social Work Core Course}

\begin{tabular}{|c|c|c|}
\hline Unacceptable & Acceptable & Exemplary \\
\hline 0 & 7 & 11 \\
\hline
\end{tabular}

\section{Reasons for Rating}

\begin{tabular}{|c|c|c|}
\hline $\begin{array}{l}\text { No respondent rated } \\
\text { the core course less than } \\
\text { acceptable }\end{array}$ & $\begin{array}{l}\text { - Core course is new } \\
\text { and piloted with a focus on } \\
\text { economic justice perspective } \\
\text { with full faculty buy in } \\
\text { - Core course offers } \\
\text { hands on experience in Mexico } \\
\text { with an added positive that } \\
\text { students learn Spanish which } \\
\text { is a competency that is } \\
\text { stressed } \\
\text { g Focus of this class on } \\
\text { globalization and its } \\
\text { importance in several areas } \\
\text { not just social work }\end{array}$ & $\begin{array}{l}\text { - Core course offers } \\
\text { experience abroad } \\
\text { member with experience as an } \\
\text { melass taught by faculty } \\
\text { international social worker } \\
\text { incorporated into concentration } \\
\text { for political social work with an } \\
\text { emphasis on peace and global } \\
\text { justice }\end{array}$ \\
\hline
\end{tabular}

\section{Format: International Social Work Offered As An Elective With Opportunity}

\section{For Field Trip}

Respondents were asked to evaluate international social work if their programs offered the course as an elective with the opportunity for field trips (Table 25). Fifty-eight percent of those who responded offer international social work as an elective with the opportunity for a field trip ( 5 did not respond). Thirty- 
one respondents rated their elective with field trips. Opportunity was then

provided for respondents to give reasons for their ratings.

Table 25

Format: International Social Work Elective With Field Trip

\begin{tabular}{|c|c|c|}
\hline & $n$ & $\%$ \\
\hline Yes & 28 & 57.6 \\
\hline No & 38 & 42.4 \\
\hline Total & 66 & 100.0 \\
\hline
\end{tabular}

Rate Quality of International Social Work Elective With Field Trip

\begin{tabular}{|c|c|c|}
\hline Unacceptable & Acceptable & Exemplary \\
\hline 0 & 15 & 16 \\
\hline
\end{tabular}

\section{Reasons for Rating}

\begin{tabular}{|c|c|c|}
\hline $\begin{array}{l}\text { No respondent rated } \\
\text { the elective with field trip as } \\
\text { unacceptable }\end{array}$ & $\begin{array}{l}\text { Elective is arranged } \\
\text { around either special topics or } \\
\text { research project that is offered } \\
\text { and conducted abroad } \\
\text { Elective course } \\
\text { focuses on international issues } \\
\text { with field experience } \\
\text { provides students the } \\
\text { opportunity to learn outside } \\
\text { the US, many of whom have } \\
\text { not traveled nor studied } \\
\text { abroad }\end{array}$ & $\begin{array}{l}\text { - The use of current } \\
\text { international data and focus on } \\
\text { global issues allows for timely } \\
\text { course } \\
\text { United Nations resources } \\
\text { utilized } \\
\text { international social work } \\
\text { experience offered and } \\
\text { independent study offered } \\
\text { following residential } \\
\text { experience } \\
\text { - Graduate level work } \\
\text { with two week intensive } \\
\text { immersion } \\
\text { - Student feedback } \\
\text { overwhelmingly positive }\end{array}$ \\
\hline
\end{tabular}

\section{Format: International Social Work Offered As An Elective Without Opportunity For Field Trip}

Respondents were asked to evaluate international social work if their programs offered the course as an elective without the opportunity for field trips (Table 26). Thirty-one percent of those who responded offer international social 
work as an elective without the opportunity for a field trip (9 did not respond).

Seventeen respondents rated their elective with field trips. Opportunity was then provided for respondents to give reasons for their ratings.

\section{Table 26}

Format: International Social Work Elective Without Field Trip

\begin{tabular}{|c|c|c|}
\hline & $n$ & $\%$ \\
\hline Yes & 19 & 30.6 \\
\hline No & 43 & 69.4 \\
\hline Total & 62 & 100.0 \\
\hline
\end{tabular}

Rate Quality of International Social Work Elective Without Field Trip

\begin{tabular}{|c|c|c|}
\hline Unacceptable & Acceptable & Exemplary \\
\hline 0 & 8 & 9 \\
\hline
\end{tabular}

Reasons for Rating

\begin{tabular}{|l|l|l|}
\hline $\begin{array}{l}\text { No respondent rated } \\
\text { the elective without field trip as } \\
\text { unacceptable }\end{array}$ & $\begin{array}{c}\text { Student feedback and } \\
\text { elective was topic focused }\end{array}$ & $\begin{array}{l}\text { Elective course } \\
\text { content is based upon faculty } \\
\text { member with international } \\
\text { experience }\end{array}$ \\
\hline
\end{tabular}

\section{Format: International Content is Limited To Field Trips}

Table 27 shows international social work content that is limited to field trips abroad within the social work curriculum and without specific course requirements. Eight respondents chose not to answer. Nine of those who responded have limited curriculum content while 54 responded that the international social work content is not limited to field trips without any specific requirements. Respondents then rated the quality of these field experiences (Table 27). None of the respondents rated the quality of their field experiences less than acceptable. Respondents were given the opportunity to explain their ratings. 
Table 27

Format: International Social Work Content is Limited to Field Trips

\begin{tabular}{|c|c|c|}
\hline & $n$ & $\%$ \\
\hline Yes & 9 & 14.3 \\
\hline No & 54 & 85.7 \\
\hline Total & 63 & 100.0 \\
\hline
\end{tabular}

Rate Quality of International Social Work Content Limited To Field Trips

\begin{tabular}{|c|c|c|}
\hline Unacceptable & Acceptable & Exemplary \\
\hline 0 & 5 & 5 \\
\hline
\end{tabular}

\section{Reasons for Rating}

\begin{tabular}{|c|c|c|}
\hline $\begin{array}{l}\text { No respondent rated } \\
\text { the elective without field trip as } \\
\text { unacceptable }\end{array}$ & $\begin{array}{l}\text { Trips have an } \\
\text { excellent level of preparation } \\
\text { and staff support } \\
\text { - Students have } \\
\text { opportunity for "hands on" } \\
\text { experience }\end{array}$ & $\begin{array}{l}\text { - Outstanding cross- } \\
\text { cultural engagement } \\
\text { - BSW and MSW } \\
\text { students attend a variety of } \\
\text { learning opportunities }\end{array}$ \\
\hline
\end{tabular}

\section{Format: International Social Work Offered As Specialization Without}

\section{Infusion Into Existing Curriculum}

International social work content was then explored as a specialization (separate tract) without infusion into existing curriculum. Of those who responded, only one $(1.1 \%)$ responded that they do offer international social work as a specialization even though it is not infused into the rest of the social work curriculum. Ninety-nine percent do not offer international social work only as a specialization without infusion into other classes (Table 28). One respondent rated the specialization as exemplary but no reasons were provided for the rating. 
Table 28

Forma: -ISW Offered as Specialization Without Infusion Into Existing Curriculum

\begin{tabular}{|c|c|c|}
\hline & $n$ & $\%$ \\
\hline Yes & 1 & 1.5 \\
\hline No & 70 & 98.5 \\
\hline Total & 71 & 100.0 \\
\hline
\end{tabular}

Rate Quality of International Social Work Specialization Without Infusion

\begin{tabular}{|c|c|c|}
\hline Unacceptable & Acceptable & Exemplary \\
\hline 0 & 0 & 1 \\
\hline
\end{tabular}

Format: International Social Work Offered As Specialization With Infusion Into Existing Curriculum

International social work content was then explored as a specialization (separate tract) and infused into existing social work curriculum (Table 29). Five $(5.4 \%)$ responded that they offer international social work as a specialization and it is also infused into the existing social work curriculum. Seven chose not to respond.

Table 29

Format: ISW Offered as Specialization With Infusion Into Existing Curriculum

\begin{tabular}{|c|c|c|}
\hline & $\mathrm{n}$ & $\%$ \\
\hline Yes & 5 & 7.8 \\
\hline No & 59 & 92.2 \\
\hline Total & 64 & 100.0 \\
\hline
\end{tabular}

Rate Quality of International Social Work Specialization With Infusion

\begin{tabular}{|c|c|c|}
\hline Unacceptable & Acceptable & Exemplary \\
\hline 0 & 3 & 2 \\
\hline
\end{tabular}


Reasons for Rating

\begin{tabular}{|c|c|c|}
\hline $\begin{array}{l}\text { No respondent rated } \\
\text { the specialization and also } \\
\text { infusion as unacceptable }\end{array}$ & $\begin{array}{l}\text { - Specialization fairly } \\
\text { well developed with sound } \\
\text { content } \\
\text { - Infusion into the social } \\
\text { work content underway but } \\
\text { needs to be improved }\end{array}$ & $\begin{array}{l}\text { - Improvement of } \\
\text { course each year } \\
\text { - Faculty receives } \\
\text { ongoing training and } \\
\text { experience at the international } \\
\text { level and bringing this training } \\
\text { and experience into the } \\
\text { classroom }\end{array}$ \\
\hline
\end{tabular}

\section{Format: International Social Work Offered As Core, Elective, and Infused}

\section{Into Existing Curriculum}

Table 30 shows international social work content that is offered as a core course, an elective, and infused into the existing social work curriculum. Ten of those who responded offer international social work in all three ways. Fifty-four responded that international social work is not offered in these three ways.

Seven respondents chose not to answer. Table 30 illustrates the frequency, ratings, and reasons for the ratings.

Table 30

Format: ISW Offered as Core, Elective, and Infused Into Existing

\section{Curriculum}

\begin{tabular}{|c|c|c|}
\hline & $\mathrm{n}$ & $\%$ \\
\hline Yes & 10 & 15.6 \\
\hline No & 54 & 84.4 \\
\hline Total & 64 & 100.0 \\
\hline
\end{tabular}

Rate Quality of International Social Work Offered As Core, Elective, and Infusion Into Existing Curriculum

\begin{tabular}{|c|c|c|}
\hline Unacceptable & Acceptable & Exemplary \\
\hline 1 & 3 & 6 \\
\hline
\end{tabular}


Reasons for Rating

- The one respondent $\quad$ - International social

did not provide reasons for the rating

\section{Format: Practicum Abroad Offered As Part of International Social Work}

\section{Curriculum}

Respondents were then asked about the opportunity for students to participate in an international social work practicum. Thirty-sex percent of those who responded (23) do offer students the opportunity to participate in such a practicum. Forty-one respondents $(64 \%)$ do not offer such a practicum experience. Seven respondents did not answer (Table 31). Fourteen respondents rated their practicum experience as exemplary and eight rated the experience as acceptable. Respondents provide reasons for their ratings and provided the countries that are offered as choices to students for the practicum experience.

\section{Table 31}

Format: Overseas Practicum Offered as Part of International Social Work

\section{Curriculum}

\begin{tabular}{|c|c|c|}
\hline & $\mathrm{n}$ & $\%$ \\
\hline Yes & 23 & 35.9 \\
\hline No & 41 & 64.1 \\
\hline Total & 64 & 100.0 \\
\hline
\end{tabular}

Rate Quality of International Social Work Practicum

\begin{tabular}{|c|c|c|}
\hline Unacceptable & Acceptable & Exemplary \\
\hline 1 & 8 & 14 \\
\hline
\end{tabular}


Reasons for Rating

\begin{tabular}{|c|c|c|}
\hline $\begin{array}{l}\text { When practicum is } \\
\text { offered, it is sound. However, } \\
\text { practicum is not offered on a } \\
\text { regular basis } \\
\text { offering and arranging a } \\
\text { practicum abroad }\end{array}$ & $\begin{array}{l}\text { - Practicum in several } \\
\text { areas is underdeveloped } \\
\text { - Relationship with a } \\
\text { university abroad that offers } \\
\text { the opportunity of practicum } \\
\text { being available yearly } \\
\text { - A new program and } \\
\text { only one student has taken } \\
\text { advantage of the opportunity } \\
\text { but rated the experience highly }\end{array}$ & $\begin{array}{l}\text { - Practicum a valuable } \\
\text { experience and popular } \\
\text { - Combines language } \\
\text { and social work skills training } \\
\text { in a local community } \\
\text { available } \\
\text { number of countries } \\
\text { negotiated and follow-up with } \\
\text { students in the placements is } \\
\text { utilized } \\
\text { goals are clearly defined and } \\
\text { an international field manual } \\
\text { has been developed } \\
\text { semester in advance to the } \\
\text { sements } \\
\text { actual practicum placement }\end{array}$ \\
\hline
\end{tabular}

The countries offered for practica abroad vary from program to program.

The countries available for practica included those found in Central America, South America, Europe, Asia, Africa, the Caribbean, and the South Pacific.

\section{Format: Technology Used To Enhance International Social Work Content}

The final aspect in the curriculum content section looked at the use of technology to enhance international social work curriculum. Forty-eight percent of those who responded (29) use technology to enhance their international social work curriculum. Fifty-three percent of those who responded (32) do not use technology to enhance their international social work curriculum. Ten chose not to respond (Table 32). No one rated their use of technology as unacceptable and $56 \%$ of those who responded (15) rated their use of technology as exemplary. Two respondents did not rate their use of technology. 
Table 32

Format: Technology Used to Enhance International Social Work Content

\begin{tabular}{|c|c|c|}
\hline & $n$ & $\%$ \\
\hline Yes & 29 & 47.5 \\
\hline No & 32 & 52.5 \\
\hline Total & 61 & 100.0 \\
\hline
\end{tabular}

Rate Quality of Technology Used To Enhance International Social Work Content

\begin{tabular}{|c|c|c|}
\hline Unacceptable & Acceptable & Exemplary \\
\hline 0 & 12 & 15 \\
\hline
\end{tabular}

Reasons for Rating

\begin{tabular}{|c|c|c|}
\hline $\begin{array}{l}\text { No respondent rated } \\
\text { the use of technology to } \\
\text { enhance international social } \\
\text { work curriculum as } \\
\text { unacceptable }\end{array}$ & $\begin{array}{l}\text { Students given } \\
\text { laptops and must use to } \\
\text { remain a virtual member of the } \\
\text { class } \quad \text { Assignments sent via } \\
\text { electronic submission } \\
\text { classroom topics with each } \\
\text { other via Blackboard } \\
\text { feed cameral in the future with } \\
\text { Internet connections to other } \\
\text { countries } \\
\text { - Students on field trips } \\
\text { or practicum use email to send } \\
\text { weekly journals to their field } \\
\text { supervisor } \\
\text { t Use of } \\
\text { teleconferencing used to make } \\
\text { "site" visits }\end{array}$ & $\begin{array}{l}\text { Use of contemporary } \\
\text { websites and an interactive } \\
\text { classroom website to enhance } \\
\text { classroom experience } \\
\text { Experimenting utilizing } \\
\text { webCt to provide guest } \\
\text { lecturers from other countries } \\
\text { and video links to classrooms } \\
\text { in other counties allows for } \\
\text { cross-national discussions } \\
\text { Online sessions allow } \\
\text { for forums and postings from } \\
\text { anywhere in the world }\end{array}$ \\
\hline
\end{tabular}

\section{Summary of International Social Work Curriculum Format}

Of those who responded to the survey, the process of offering

international social work as a component of the social work curriculum varies

from not offering an international component to offering international as core,

elective, and specialization within one program. Some programs offer classes

with a field experience and others only offer the field experience. Although 
offering a practicum entails overcoming some hurdles, programs are offering a practicum experience abroad and some programs are using technology in creative ways to enhance the international component (Table 33).

\section{Table 33}

International Social Work Curriculum Format Summary

\begin{tabular}{|l|c|}
\hline \multicolumn{1}{|c|}{ Type of Format } & Number of Schools \\
\hline Infused or offered as specific course & 71 \\
In process of adding international content & 8 \\
Offer a core course within specialization & 19 \\
Offer elective with field trip & 28 \\
Offer elective without field trip & 19 \\
Content is limited to field trip & 9 \\
Specialization offered without infusion & 1 \\
Specialization offered with infusion & 5 \\
Offered as core, specialization, and elective & 10 \\
Practicum abroad offered & 23 \\
Technology used to enhance content & 29 \\
\end{tabular}

Looking at those who rated the quality of the international social work format within the social work curriculum and utilizing those responses to inform anchor points of unacceptable, acceptable, and exemplary, the following can be said. Those who rated the international component as unacceptable began with the fact that international social work content is not offered. Those programs that do offer international social work content and rated the format as unacceptable have infusion formatting that is not complete, often limited to within policy class, and content is dependent upon individual faculty. When an elective is offered, the elective is limited to one class. A practicum abroad is not offered or not offered on a regular basis. International social work does not command the 
interest or the attention of students. International social work content is just beginning to be offered as part of the social work curriculum.

Those that provided ratings as acceptable provided that an elective, formal course, or specialization is offered that is fairly well developed with sound content. If the international content is infused, the infusion occurs across the entire social work curriculum and provides that all social work students are exposed to international social work. While infusion occurs, there are areas that need improvement. Other reasons offered for giving an acceptable rating included (a) a practicum abroad is offered on a yearly basis, (b) field experiences have excellent preparation and staff support, and (c) faculty is excellent and highly committed. Technology is used to enhance the international content with students using Blackboard to discuss classroom topics, assignments being sent via electronic submission, students on field or practicum use email to send weekly journal reports, or teleconferencing is used to make site visits abroad. Live feed cameras are utilized with internet connections to provide connections with classrooms abroad.

Those that rated the format as exemplary explained that the international social work content is constantly being reviewed and updated. Guest lectures are utilized and outside resources (e.g. United Nations research data) are utilized. Current international data are presented and the focus of the content includes current global issues. Faculty receives ongoing training that enhances the classroom experience and there is faculty exchange. A practicum abroad combines language and social work skills and the practicum has clear field 
contracts and student goals. A residential field experience is offered with possible independent study following residential experience. Technology is used to enhance the international component. Examples of exemplary use of technology include (a) an interactive website is utilized to enhance the classroom experience, (b) WebCt or other program provides links to lecturers from other countries or video links to classrooms in other countries allows for cross-national discussions, and (c) online sessions allow for forums and postings from anywhere in the world.

\section{Infusion of International Social Work Content}

This third section focused on those who infuse international social work content into the social work curriculum. Respondents were specifically asked to rate the infusion of the key areas of international social work best teaching practices based on the 2002 CSWE Educational Policy and Accreditation Standards. The specific content areas included (a) diversity, (b) populations at risk/social and economic justice, (c) human behavior in the social environment, (d) social welfare policy, (e) cross-cultural knowledge, (f) values and ethics, (g) social problems, and $(\mathrm{h})$ human oppression.

\section{Infusion: Diversity Infused into Social Work Curriculum}

Table 34 shows the infusion of diversity into existing social work classes. Eighty-five percent (55) responded that diversity was infused into the curriculum. Fifteen percent responded that diversity was not infused into the curriculum. Six respondents chose not to answer the question. 
as exemplary. Ten respondents chose not to rate the infusion of diversity.

\section{Table 34}

Diversity Infused Into Social Work Curriculum

\begin{tabular}{|c|c|c|}
\hline & $\mathrm{n}$ & $\%$ \\
\hline Yes & 55 & 84.6 \\
\hline No & 10 & 15.4 \\
\hline Total & 65 & 100.0 \\
\hline
\end{tabular}

Rate Quality of Diversity Infusion

\begin{tabular}{|c|c|c|}
\hline Unacceptable & Acceptable & Exemplary \\
\hline 3 & 37 & 15 \\
\hline
\end{tabular}

\section{Reasons for Rating}

- Infusion of diversity
not consistent throughout
curriculum
upon individual faculty
members
mandatory Infusion not
- Lack of student
interest

to some degree

- Infused in accordance

with instructor's range of experience

- Could be enhanced

- Well-versed faculty include readings and lectures - Diversity infused through major assignments which require students to read, research, and reflect on international customs, issues, resources, needs, and policies

- Focus of school of social work and mission statement is working with oppressed peoples - Infused into all courses via education objectives for the specific courses and human diversity is core as foundation course

- $\quad$ Comparative HBSE and practice variations depend on culture and policy implications based on ethnic and cultural differences are important aspects but not significantly impressed upon all students as a central component of diversity

- Current emphasis on valuing differences within specific group differences used as examples to sensitize students to other perspectives
Very similar to international issues and faculty feel comfortable with diversity - All core courses infuse diversity as an essential component of the course - Included on all syllabi - A focus on international social work must stress the true meaning and application of multicultural practice. Students are exposed and work on the practice concepts of interacting effectively with individuals from other cultures 


\section{Infusion: Populations at Risk/Economic Justice Infused Into Social Work}

\section{Curriculum}

Table 35 provides data on the infusion of populations at risk/economic justice into the social work curriculum. Of those who responded, $78 \%$ reported that this area is infused into the social work curriculum. Twenty-two percent reported that this area is not infused into the social work curriculum. Eight respondents chose not to answer this question.

Four percent of those who responded rated the infusion of this area of the curriculum as unacceptable. Thirty respondents $(63 \%)$ rated the infusion as acceptable and 16 respondents $(33 \%)$ rated the infusion as exemplary. Fifteen respondents chose not to answer the question. Respondents were provided the opportunity to give reasons for their rating.

\section{Table 35}

Infusion: Populations at Risk/Economic Justice Infused into Social Work

\section{Curriculum}

\begin{tabular}{|c|c|c|}
\hline & $\mathrm{n}$ & $\%$ \\
\hline Yes & 49 & 77.8 \\
\hline No & 14 & 22.2 \\
\hline Total & 63 & 100.0 \\
\hline
\end{tabular}

Rate Quality of Populations at Risk/Economic Justice Infusion

\begin{tabular}{|c|c|c|}
\hline Unacceptable & Acceptable & Exemplary \\
\hline 2 & 30 & 16 \\
\hline
\end{tabular}


Reasons for Rating

\begin{tabular}{|c|c|c|}
\hline $\begin{array}{l}\text { Infusion not } \\
\text { consistent throughout } \\
\text { curriculum, doesn't exist in all } \\
\text { classes } \\
\text { - Infusion dependent } \\
\text { upon individual faculty and } \\
\text { those with more direct } \\
\text { experience and knowledge } \\
\text { do it more frequently } \\
\text { interest Lack of student }\end{array}$ & $\begin{array}{l}\text { - Addressed in all } \\
\text { classes to some degree as } \\
\text { part of generalist practice but } \\
\text { could be better infused } \\
\text { - Global issues of } \\
\text { poverty discussed with } \\
\text { consideration of UN } \\
\text { Millennium goals } \\
\text { - We examine welfare } \\
\text { state of various nations in } \\
\text { relation to United States, } \\
\text { impact of refugee and } \\
\text { immigration in other nations in } \\
\text { relation to United States } \\
\text { - International } \\
\text { distributive justice addressed } \\
\text { pertaining to economic and } \\
\text { social justice }\end{array}$ & $\begin{array}{l}\text { Faculty teach not only } \\
\text { from the classroom setting but } \\
\text { actually take international trips } \\
\text { with students } \\
\text { always improve regarding } \\
\text { alwalial and economic justice. } \\
\text { International social work } \\
\text { moves classroom teaching, } \\
\text { discussion, and learning into } \\
\text { realistic work with populations } \\
\text { at risk, human rights } \\
\text { violations, poverty, and } \\
\text { pandemic illnesses. } \\
\text { ap Infusion into macro } \\
\text { approaches allows for } \\
\text { exploration into combating } \\
\text { social/ economic justice } \\
\text { worldwide }\end{array}$ \\
\hline
\end{tabular}

\section{Infusion: Human Behavior in the Social Environment Into Social Work}

\section{Curriculum}

When looking at the area of human behavior in the social environment (Table 36), $65 \%$ of those who responded indicated that this area of the curriculum is infused. Thirty-five percent indicated that this area is not infused into the social work curriculum. Seventeen respondents chose not to answer.

Two respondents rated the infusion as unacceptable (6\%). Twenty-one respondents rated the infusion as acceptable (66\%) while $28 \%$ (9 respondents) rated the infusion as exemplary. Respondents were then asked to provide reasons for their ratings. 


\section{Table 36}

Infusion: Human Behavior in the Social Environment Infused Into Social

Work Curriculum

\begin{tabular}{|c|c|c|}
\hline & $\mathbf{n}$ & $\%$ \\
\hline Yes & 35 & 64.8 \\
\hline No & 19 & 35.2 \\
\hline Total & 54 & 100.0 \\
\hline
\end{tabular}

Rate Quality of Human Behavior in the Social Environment Infusion

\begin{tabular}{|c|c|c|}
\hline Unacceptable & Acceptable & Exemplary \\
\hline 2 & 21 & 9 \\
\hline
\end{tabular}

\section{Reasons for Rating}

\begin{tabular}{|c|c|c|}
\hline $\begin{array}{l}\text { Infusion not consistent } \\
\text { throughout curriculum, doesn't } \\
\text { exist in all classes } \\
\text { upon individual faculty and } \\
\text { those with more direct } \\
\text { experience and knowledge do } \\
\text { it more frequently } \\
\text { interest Lack of student }\end{array}$ & $\begin{array}{l}\text { - Cultural differences in } \\
\text { the developmental cycle is } \\
\text { infused } \\
\text { development } \\
\text { readings and class discussion } \\
\text { Where are required } \\
\text { being infusion to life across } \\
\text { each system level, from } \\
\text { individual to family to group to } \\
\text { organization to neighborhood } \\
\text { to community to policy to } \\
\text { globe } \\
\text { One HBSE course is } \\
\text { titled "multicultural } \\
\text { perspectives" which is a core } \\
\text { course and does include } \\
\text { significant amount of resource } \\
\text { material related to } \\
\text { international }\end{array}$ & $\begin{array}{l}\text { Cultural differences } \\
\text { and the impact on human } \\
\text { behavior is explored }\end{array}$ \\
\hline
\end{tabular}

\section{Infusion: Social Welfare Policy Infused Into Social Work Curriculum}

The infusion of social welfare policy into the social work curriculum is presented in Table 37. Seventy-four percent of those who responded (42) reported that social welfare policy is infused into the social work curriculum while 
$26 \%$ (15 respondents) indicated that social welfare policy is not infused.

Fourteen respondents chose not to answer.

Five percent ( 2 respondents) rated the infusion as unacceptable. Twentytwo respondents $(60 \%)$ rated the infusion as acceptable and $37 \%(14$ respondents) rated the infusion as exemplary (Table 37). Nineteen respondents chose not to answer. The opportunity was then presented to respondents to provide reasons for the ratings.

\section{Table 37}

Infusion: Social Welfare Policy Infused into Social Work Curriculum

\begin{tabular}{|c|c|c|}
\hline & \multicolumn{2}{|c|}{} \\
\hline Yes & 42 & 73.7 \\
\hline No & 15 & 26.3 \\
\hline Total & 57 & 100.0 \\
\hline
\end{tabular}

Rate Quality of Social Welfare Policy Infusion

\begin{tabular}{|c|c|c|}
\hline Unacceptable & Acceptable & Exemplary \\
\hline 2 & 22 & 14 \\
\hline
\end{tabular}


Reasons for Rating

\begin{tabular}{|c|c|c|}
\hline $\begin{array}{l}\text { Insufficient time } \\
\text { devoted to this } \\
\text { presented in policy courses } \\
\text { minimally and not infused into } \\
\text { other courses } \\
\text { interest Lack of student } \\
\text { individual instructor }\end{array}$ & $\begin{array}{l}\text { - All policy courses } \\
\text { focus on international social } \\
\text { welfare policies } \\
\text { comparisons are made and } \\
\text { serve as illustrations for } \\
\text { developing students' critical } \\
\text { thinking and analytical skills } \\
\text { in policy courses } \\
\text { in by CSWE } \\
\text { not infusion is present but } \\
\text { not impressed as central and } \\
\text { uneven across sections } \\
\text { course uses a book that has a } \\
\text { section on international social } \\
\text { welfare and at least one } \\
\text { specific class session devoted } \\
\text { to this topic } \\
\text { - Our advanced policy } \\
\text { course included curriculum } \\
\text { which addresses international } \\
\text { populations but material is not } \\
\text { a core component of the } \\
\text { course. There is an elective } \\
\text { which concentrates on policy } \\
\text { issues within an international } \\
\text { setting }\end{array}$ & $\begin{array}{l}\text { International models } \\
\text { of social welfare are } \\
\text { presented. Students are } \\
\text { required to include } \\
\text { international content within } \\
\text { assignments } \\
\text { - Our concentration } \\
\text { level policy course focuses on } \\
\text { family policy from a domestic } \\
\text { and international viewpoint. } \\
\text { Students conduct comparative } \\
\text { policy analysis }\end{array}$ \\
\hline
\end{tabular}

\section{Infusion: Cross-Cultural Knowledge and Skills Infused Into Social Work}

\section{Curriculum}

The infusion of cross-cultural knowledge and skills is the focus of Table 38. Forty-nine respondents (85\%) indicated that cross-cultural knowledge and skills are infused into the social work curriculum. Sixteen percent of those who responded (9 respondents) reported that this area is not infused into the social work curriculum. Thirteen respondents chose not to answer.

Seven percent of those who responded (3) rated the infusion as unacceptable. Thirty-one respondents gave the infusion an acceptable rating. Twelve respondents rated the infusion as exemplary. Twelve respondents chose 
not to answer. Opportunity was provided the respondents to give reasons for

their ratings.

Table 38

Infusion: Cross-Cultural Knowledge and Skill Infused Into Social Work

Curriculum

\begin{tabular}{|c|c|c|}
\hline & $\mathrm{n}$ & $\%$ \\
\hline Yes & 49 & 84.5 \\
\hline No & 9 & 15.5 \\
\hline Total & 58 & 100.0 \\
\hline
\end{tabular}

Rate Quality of Cross-Cultural Knowledge and Skill Infusion

\begin{tabular}{|c|c|c|}
\hline Unacceptable & Acceptable & Exemplary \\
\hline 3 & 31 & 12 \\
\hline
\end{tabular}

\section{Reasons for Rating}

\begin{tabular}{|c|c|c|}
\hline $\begin{array}{l}\text { Insufficient time } \\
\text { devoted to this } \\
\text { classes Not infused into all } \\
\text { interest Lack of student } \\
\text { individual instructor }\end{array}$ & $\begin{array}{l}\text { - Focus of our school of } \\
\text { social work } \\
\text { - A special course } \\
\text { offered on this topic } \\
\text { field courses and overseas } \\
\text { elective } \\
\text { - Multi-cultural practice } \\
\text { stressed in practice classes as } \\
\text { well as in international social } \\
\text { work course. } \\
\text { - Role playing and } \\
\text { problem solving situation } \\
\text { involving cross-cultural } \\
\text { knowledge } \\
\text { imf Infused in relation to } \\
\text { immigrant populations } \\
\text { - Emphasized in multi- } \\
\text { cultural perspectives and } \\
\text { international policy course } \\
\text { - Recognition and } \\
\text { identification of diversity in } \\
\text { values and perspectives focus } \\
\text { on self-awareness and skill } \\
\text { building }\end{array}$ & $\begin{array}{l}\text { A certificate for } \\
\text { working with Latino } \\
\text { populations is being prepared } \\
\text { and work has been done in } \\
\text { promotion and orientation to } \\
\text { this program } \\
\text { Publishing being done } \\
\text { in this area with use of } \\
\text { dialogue groups in teaching } \\
\text { diversity and inequality }\end{array}$ \\
\hline
\end{tabular}




\section{Infusion: Values and Ethics Infused Into Social Work Curriculum}

Table 39 provides data on the infusion of ethics and values into the social work curriculum. Of those who responded, $68 \%$ (39 respondents) reported that values and ethics are infused into the curriculum and $32 \%(18)$ indicated that this area is not infused into the curriculum. Fourteen respondents chose not to answer.

Of those who rated the infusion, $9 \%$ (3 respondents) rated this area of infusion as unacceptable. Twenty-one or $60 \%$ rated the infusion as acceptable and 11 respondents $(31 \%)$ rated the infusion as exemplary. Twenty-two respondents chose not to answer. Respondents were then given the opportunity to explain their ratings.

Table 39

Infusion: Values and Ethics Infused Into Social Work Curriculum

\begin{tabular}{|c|c|c|}
\hline & $\mathrm{n}$ & $\%$ \\
\hline Yes & 39 & 68.4 \\
\hline No & 18 & 31.6 \\
\hline Total & 57 & 100.0 \\
\hline
\end{tabular}

Rate Quality of Values and Ethics Infusion

\begin{tabular}{|c|c|c|}
\hline Unacceptable & Acceptable & Exemplary \\
\hline 3 & 21 & 11 \\
\hline
\end{tabular}


Reasons for Rating

\begin{tabular}{|c|c|c|}
\hline $\begin{array}{l}\text { Insufficient time } \\
\text { devoted to this } \\
\text { classes Not infused into all } \\
\text { interest Lack of student } \\
\text { individual instructor }\end{array}$ & $\begin{array}{l}\text { - Curriculum being } \\
\text { developed in this area with focus } \\
\text { on United Nations Human Rights } \\
\text { field courses and international } \\
\text { overseas elective } \\
\text { utilized NASW Code of Ethics } \\
\text { of ethics of the International } \\
\text { Federation of Social Workers and } \\
\text { comparison with domestic codes } \\
\text { and study underlying principles of } \\
\text { other human rights documents } \\
\text { addressed in multi-cultural } \\
\text { addues and ethics } \\
\text { perspectives and international } \\
\text { policy courses but not } \\
\text { emphasized throughout } \\
\text { curriculum } \\
\text { Infusion central to } \\
\text { developing awareness and } \\
\text { insight of students into their } \\
\text { own cultural beliefs and values }\end{array}$ & $\begin{array}{l}\text { - Professional values } \\
\text { and ethics infused into all } \\
\text { courses as well as discussion } \\
\text { of the relative nature of values } \\
\text { in different cultures and } \\
\text { societies } \\
\text { rights and social justice } \\
\text { - Incorporation of the } \\
\text { code of ethics of NASW and } \\
\text { IFSW as well as other } \\
\text { countries into classroom } \\
\text { discussions, studying } \\
\text { underlying principles, and } \\
\text { identification of ethical } \\
\text { dilemmas }\end{array}$ \\
\hline
\end{tabular}

\section{Infusion: Social Problems Infused Into Social Work Curriculum}

When looking at the area of infusion of social problems into the social work curriculum (Table 40 ), $72 \%$ of those who responded (41) indicated that this area was infused into the social work curriculum. Sixteen of the respondents $(28 \%)$ reported that this area is not infused into the social work curriculum.

Fourteen respondents chose not to answer.

Eight percent of those who responded (3) rated the quality of infusion as unacceptable. Twenty-seven respondents $(73 \%)$ rated the infusion of this area as acceptable. Seven respondents (19\%) gave this infusion an exemplary rating. Fifty-five chose not to respond. The respondents were then given the opportunity to explain the ratings. 
Table $\mathbf{4 0}$

Infusion: Social Problems Infused Into Social Work Curriculum

\begin{tabular}{|c|c|c|}
\hline & $n$ & $\%$ \\
\hline Yes & 41 & 71,9 \\
\hline No & 16 & 28.1 \\
\hline Total & 57 & 100.0 \\
\hline
\end{tabular}

Rate Quality of Social Problems Infusion

\begin{tabular}{|c|c|c|}
\hline Unacceptable & Acceptable & Exemplary \\
\hline 3 & 27 & 7 \\
\hline
\end{tabular}

\section{Reasons for Rating}

\begin{tabular}{|c|c|c|}
\hline $\begin{array}{l}\text { Insufficient time } \\
\text { devoted to this } \\
\text { Not infused into all } \\
\text { classes Lack of student } \\
\text { interest Depends upon the } \\
\text { individual instructor }\end{array}$ & $\begin{array}{l}\text { Infused into } \\
\text { international field courses and } \\
\text { international overseas elective } \\
\text { Policy II } \\
\text { othtegrated into Social } \\
\text { other countries utilized as a } \\
\text { learning tool for students to } \\
\text { critique } \\
\text { central to our region examined } \\
\text { as well as other global issues. } \\
\text { This area needs strengthening } \\
\text { Faculty attempt } \\
\text { infusion for comparative } \\
\text { purposes } \\
\text { This is a new area of } \\
\text { focus and used on macro level } \\
\text { as we examine the role that } \\
\text { corporations play in social } \\
\text { problems } \\
\text { - Tapping colleagues' } \\
\text { work in other programs }\end{array}$ & $\begin{array}{l}\text { Use of the United } \\
\text { Nations Wire as well as other } \\
\text { resources for weekly updating } \\
\text { of classes to the extent and } \\
\text { nature of the shifting social } \\
\text { problems in the world (i.e. bird } \\
\text { flue, access to vaccines) }\end{array}$ \\
\hline
\end{tabular}

\section{Infusion: Human Oppression Infused Into Social Work Curriculum}

Human oppression was the final area of infusion into the social work curriculum that was researched (Table 41$)$. Of those who responded, $47(84 \%)$ indicated that this was an area of infusion into the social work curriculum. Nine 
(16\%) responded that this was not an area of infusion. Fifteen chose not to respond.

Of those who responded (Table 41$)$, one $(2 \%)$ indicated that this area of infusion was unacceptable. Sixty-five percent or 28 respondents rated this infusion as acceptable. Fourteen respondents or $15 \%$ rated the infusion as exemplary. Thirteen chose not to respond. The opportunity was then given to respondents to explain their ratings.

\section{Table 41}

\section{Infusion:Human Oppression Infused Into Social Work Curriculum}

\begin{tabular}{|c|c|c|}
\hline & $\mathrm{n}$ & $\%$ \\
\hline Yes & 47 & 83.9 \\
\hline No & 9 & 16.1 \\
\hline Total & 56 & 100.0 \\
\hline
\end{tabular}

Rate Quality of Human Oppression Infusion

\begin{tabular}{|c|c|c|}
\hline Unacceptable & Acceptable & Exemplary \\
\hline 1 & 28 & 14 \\
\hline
\end{tabular}

\section{Reasons for Rating}

\begin{tabular}{|c|c|c|}
\hline $\begin{array}{l}\text { Insufficient time } \\
\text { devoted to this } \\
\text { classes Not infused into all } \\
\text { interest Lack of student } \\
\text { individual instructor }\end{array}$ & $\begin{array}{l}\text { - Related to global } \\
\text { economy } \\
\text { events as examples of } \\
\text { oppression often used in } \\
\text { classroom to compare and } \\
\text { contrast underlying themes of } \\
\text { oppression. Especially used } \\
\text { in Diversity and Policy courses } \\
\text { development } \\
\text { Infusion needs further } \\
\text { international field and courses } \\
\text { and overseas elective } \\
\text { - Dynamics of } \\
\text { colonialism and imperialism } \\
\text { and the role of the United } \\
\text { States and the failure of the } \\
\text { international community and } \\
\text { institutions to deal effectively } \\
\text { with oppression explored }\end{array}$ & $\begin{array}{l}\text { Required course on } \\
\text { Human Oppression. Course } \\
\text { includes the use of the United } \\
\text { Nations Convention on the } \\
\text { Elimination of All forms of } \\
\text { Racial Discrimination, the } \\
\text { United States assessment, } \\
\text { and the commentary from the } \\
\text { Human Rights Commission } \\
\text { discussed and comparative } \\
\text { analysis done } \\
\text { Outside resources are } \\
\text { brought to classroom setting } \\
\text { for discussion and comparison } \\
\text { - Under the heading of } \\
\text { Human Rights, all social work } \\
\text { courses discuss the role of } \\
\text { oppression in the work and its } \\
\text { impact upon populations }\end{array}$ \\
\hline
\end{tabular}




\section{Summary of Infusion Of International Social Work Content}

Table 42 provides a summary of the status of infusion of international social work content areas. Further analysis indicate that the schools who infuse content in any of the key areas, infuse it in a mean of 6 areas $(\mathrm{SD}=2.68)$, with 25 schools infusing international content in all eight key areas. In terms of quality, the schools who infuse international content in any of the eight key areas, gave a mean rating of $4.8(S D=1.27)$, indicating an acceptable quality.

When rating the quality of infusion of international social work in the eight key areas, those respondents who rated the infusion as unacceptable provided the following for anchor points: (a) infusion is not consistent in the key areas throughout the social work curriculum, (b) infusion is dependent upon individual faculty members, (c) insufficient time devoted to infusion, and (d) lack of student interest.

Respondents who rated the quality of infusion as acceptable provided the following for anchor points: (a) infusion is addressed in all classes to some degree, (b) infusion could be enhanced, (c) infusion into all courses via education objectives, (d) emphasis on valuing differences used to sensitize students to other perspectives, (e) required outside readings and class discussion.

When looking at those who rated the quality of infusion as exemplary, the following reasons were provided: (a) all core courses infuse content, (b) stress on multicultural practice, (c) classroom setting combined with field experiences, (d) infusion of both micro and macro classes, (e) international models are presented and international content required within assignments, and (f) 
incorporation of outside reading material and other outside resources brought to classroom setting for comparison and discussion.

\section{Table 42}

International Social Work Curriculum Infusion Summary

\begin{tabular}{|l|c|}
\hline \multicolumn{1}{|c|}{ Key Areas of Infusion } & Number of Schools \\
\hline Diversity & 55 \\
Populations at Risk/Economic Justice & 49 \\
Human Behavior in Social Environment & 35 \\
Social Welfare Policy & 42 \\
Cross-Cultural Knowledge and Skill & 49 \\
Values and Ethics & 39 \\
Social Problems & 41 \\
Human Oppression & 47 \\
\hline
\end{tabular}

\section{Conclusion}

In this chapter I reported the results of the two research questions. In the last chapter are discussions of the implications of the results for (a) social work practice, (b) social work education, and (c) policy and decision makers. Limitations of this study are also discussed. 


\section{CHAPTER 5}

\section{DISCUSSION, CONCLUSIONS, AND IMPLICATIONS FOR FUTURE RESEARCH}

In this chapter, I summarize the results of this research, followed by theoretical and practical implications of the results in respect to the development of international social work within the social work curriculum. I conclude the chapter with suggestions for future research and limitations of this research.

\section{Summary, Discussion, and Conclusions}

The focus of this research was to raise our understanding about international social work within the social work curriculum. The general purpose and aim of this study was to assess the teaching practices and current status of international social work curriculum for schools of social work accredited by the CSWE and determine the emphasis on international social work. Using the 2002 EPAS as a guideline, key areas of international social work best teaching practices were identified. I then developed a survey that enabled me to assess the current status of international social work and measure components to differentiate between unacceptable, acceptable, and exemplary practices.

After researching approaches to incorporating international social work into the social work curriculum, I found that five approaches have been proposed: (a) focused, (b) infused, (c) selective, (d) concentrated, and (e) integrated. After studying the literature, I proposed the InCon approach for implementing an 
international social work best teaching practices curriculum for schools of social work. This approach uses a two-pronged approach to international social work curricula incorporating infusion with concentration. The InCon approach allows for all social work students to be exposed to international social work curricula through infusion of existing courses or specializing in this particular area of social work. This approach is based on the eight key areas as outlines in CSWE's 2002 Educational Policy and Accreditation Standards.

Those responding to the survey reported that the status of international social work curriculum within the social work curriculum varies. Some social work programs do not offer an international component, others limit it to one elective or field experience, while others infuse throughout the curriculum and/or offer as a specialization. A majority of those who offer international social work as part of the social work curriculum infuse the content or offer as a specific course. The second highest group offers an elective with a field experience.

When looking at infusing the eight key areas identified in the 2002 CSWE EPAS, again the quality of infusion varies within social work programs. Some reported that the infusion is not consistent and dependent upon individual faculty members. Others reported that infusion occurs in all classes to some degree but that the infusion could be enhanced. The final group reported that all core coursed infuse international content, that the classroom experience is combined with field experiences, and that outside materials and resources are brought into the classroom setting. 


\section{Implications for Social Work Education and Practice}

The research finds that there is a need for international social work within the social work curriculum and the survey that was part of this research provides us with the current status of international social work within the social work curriculum. Looking with a futuristic eye at the social work profession and in particular to the social work curriculum in CSWE approved schools/programs of social work in the ideal world, this could be the scenario.

There is a wide array of issues surrounding international social work within the social work curriculum. International social forces and events have changed the makeup of social work agency caseloads and affected domestic practice in many countries. New knowledge and competencies are demanded to cope with social problems and conditions on all levels of social work practice. The actions and policies of one country directly and/or indirectly affect other countries' social and economic well-being. Social work education has responsibilities for preparing future social workers to practice competently. One responsibility of social workers is the willingness and the capacity to develop and promulgate positions on social aspects of their own country's policies as well as other national policies and their effect on peoples in other countries. Social work has become a global profession as both policy and practice are shaped by global phenomena, even though social work education is impeded by the lack of a global perspective. The second responsibility surrounds the opportunities for international sharing and exchanging of information and ideas that are made possible by ever changing technology. This knowledge and experience must be 
used by social workers to improve social work practice and policy in one's own country. A third responsibility is the capacity of the social work profession to declare and publicize positions on important social issues and to contribute to the resolution of important global challenges and problems. Social workers must have both a micro and a macro outlook. International social work should be a key component within the social work curriculum.

CSWE would revisit the curriculum policy statement of 2002 with a committee comprised of social work educators and practitioners with an interest and/or experience in the international social work arena as well professionals from outside the discipline of social work. When the policy statement is revised, then all CSWE accredited Master's degree programs would offer an international social work component to the social work curriculum.

\section{Format}

The InCon approach would be utilized when offering international social work classes. This approach uses a two-pronged approach in presenting international social work within the social work curriculum: infusion and concentration. This approach allows for all social work students to be exposed to international social work either through infusing through existing courses or specializing or concentrating in this particular area of social work. There is integration of the eight-accreditation areas identified in this research into the social work curriculum. This approach would center on a vision that includes a global perspective that cuts across the entire social work curriculum. Faculty would buy into this vision and would be highly committed that would foster 
student interest. Each program would have openness to an increasing number of international students enrolling into the program.

The specialization in international social work would include a global social work perspective. The specialization would be useful for students considering careers that include but would not be limited to (a) work with immigrants and refugees, (b) inter-country adoption, (c) advocacy on global policy issues, (d) international development and, (e) broadening domestic practice through understanding the impact of international social issues. The specialization would include one core course and electives. The core course would be entitled "International Social Work". Electives could be chosen from among social work classes or classes from other disciplines with a focus on international content. Examples would include law (immigration law, international conception of rights, or rights and justice), public health (international public health issues), economics (international economic development), and education (international education issues). Independent study would be a component, particularly after a practicum experience abroad. Technology would be used to enhance the core course as well as electives. Within the core course, a contemporary interactive website would be utilized to enhance the classroom experience. Online sessions would allow for forums and posting from anywhere in the world. Video links would be utilized to provide guest lecturers from other countries and video links to classrooms in other countries would allow for cross-national discussions.

The specialization would require a one-year field placement with an organization dealing with international practice, issues, or populations or a six- 
month practicum abroad. The field placement would include but would not be limited to agencies that address immigration issues, refugees, service programs, or adoption. The practicum would require appropriate supervision and planning after the core course has been completed. The practicum would combine language skills (if necessary) and social work skills. Clear contracts would be negotiated and follow up with students would be utilized. Students' learning goals would be clearly defined and an international practicum manual would have already been developed. Students participating in a practicum abroad would have a previous semester orientation that would include introduction to the international practicum manual. Following the practicum or field experience, students would have the opportunity to share learning experiences as well as challenges. Opportunity for independent study would be provided for any interests that surfaced from the either field or practicum experience.

The curriculum would also provide an international component to all social work students through infusion of the eight key areas into the social work curriculum: (a) diversity, (b) human behavior in the social environment, (c) populations at risk/social and economic justice, (d) social welfare policy and services, (e) cross-cultural knowledge and skill, (f) values and ethics, (g) social policy and problems, and (h) human oppression.

All social work core courses would infuse the eight key areas as essential components to the social work curriculum. Assignments would require students to read, research, and reflect on international resources, needs, customs, and policies. Outside resources are brought into the classroom setting for discussion 
and comparison. International comparisons are made and serve as illustrations for developing students' critical thinking and analytical skills. The eight key areas would be infused into the educational objectives for the specific courses. Technology would be used to enhance the infusion.

\section{Suggestions for Future Research}

Past studies have focused on the need for an international dimension to social work curricula but few empirical studies have studied the outcome of this component of social work. Little research has focused on the impact of international social curricula or to assess the teaching practices of international social work curricula. While study abroad has become more prevalent, little research has been conducted to evaluate the impact of such programs on students or social work programs. The findings from this study provide a beginning understanding of how international social work can be valuable for enhancing and integrating social work values. Future research is needed to further explore the impact of international social work upon students. For those who cannot have an experience abroad, the impact of interaction with students from different countries in one's own university and the learning opportunities for personal and professional development needs to be explored. There are little data on the number and qualifications of international social work educators, variations in curricula, or types of practicum. Further research will assist social work educators to more effectively evaluate, design, and enhance international social work curricula and experiences. Based on this research, I propose the following tool for assessing teaching practices of international social work: 


\section{International Social Work Teaching Practices Survey}

1. International Social Work is a Component of Social Work Curriculum

\begin{tabular}{|c|c|c|}
\hline Unacceptable & Acceptable & Exemplary \\
\hline $\begin{array}{l}\text { International Social Work is } \\
\text { not offered, limited to field } \\
\text { experience, does not } \\
\text { command interest of } \\
\text { students, or just beginning to } \\
\text { be offered. }\end{array}$ & $\begin{array}{l}\text { International Social Work is } \\
\text { offered as an elective or } \\
\text { formal course. Faculty } \\
\text { teaching international } \\
\text { content excellent and highly } \\
\text { motivated. }\end{array}$ & $\begin{array}{l}\text { International Social Work is } \\
\text { offered as an elective, formal } \\
\text { course, specialization, and/or } \\
\text { infused across the social } \\
\text { work curriculum. Faculty } \\
\text { teaching international } \\
\text { content excellent and highly } \\
\text { motivated. Integrated } \\
\text { classroom content with study } \\
\text { abroad opportunities and } \\
\text { faculty exchange. }\end{array}$ \\
\hline 2 & 4 & 6 \\
\hline
\end{tabular}

2. International Social Work is Offered as Core Course Within Specialization

\begin{tabular}{|c|c|c|}
\hline Unacceptable & Acceptable & Exemplary \\
\hline $\begin{array}{l}\text { Core course not offered or } \\
\text { content dependent upon } \\
\text { individual faculty. }\end{array}$ & $\begin{array}{l}\text { Core course offered or is } \\
\text { new and being piloted. Focus } \\
\text { on globalization. Faculty is } \\
\text { excellent and highly } \\
\text { committed though without } \\
\text { recognized experience in the } \\
\text { field. Some collaborative } \\
\text { work with other countries. }\end{array}$ & $\begin{array}{l}\text { Core course offered, with } \\
\text { collaborative work with other } \\
\text { countries. Focus on } \\
\text { globalization, offers } \\
\text { experience abroad and } \\
\text { incorporated into } \\
\text { concentration. Faculty is } \\
\text { excellent and highly } \\
\text { committed and has } \\
\text { experience in international } \\
\text { social work or reputation in } \\
\text { international research }\end{array}$ \\
\hline 2 & 3 & 6 \\
\hline
\end{tabular}

3. International Social Work Offered as an Elective

\begin{tabular}{|c|c|c|}
\hline Unacceptable & Acceptable & Exemplary \\
\hline $\begin{array}{l}\text { Elective in international social } \\
\text { work is not offered or content } \\
\text { dependent upon individual } \\
\text { faculty. }\end{array}$ & $\begin{array}{l}\text { Elective is offered and } \\
\text { arranged around special } \\
\text { topics or research project or } \\
\text { this part of curriculum under } \\
\text { review and development. } \\
\text { Hiring of faculty with interest } \\
\text { in international research or } \\
\text { program development. }\end{array}$ & $\begin{array}{l}\text { Elective is offered and } \\
\text { arranged around special } \\
\text { topics or research project. } \\
\text { Guest lecturers utilized and } \\
\text { field experience offered. } \\
\text { Independent study offered } \\
\text { after elective. Elective } \\
\text { flexible and geared toward } \\
\text { non-traditional students. } \\
\text { Hiring of faculty with interest } \\
\text { in international research or } \\
\text { program development. }\end{array}$ \\
\hline 2 & 4 & $\begin{array}{ll}6 & 7\end{array}$ \\
\hline
\end{tabular}


4. International Social Work Offered as a Specialization

\begin{tabular}{|c|c|c|}
\hline \multicolumn{1}{|c|}{ Unacceptable } & \multicolumn{1}{|c|}{ Acceptable } & \multicolumn{1}{c|}{ Exemplary } \\
\hline $\begin{array}{l}\text { Specialization in International Work not offered or } \\
\text { content dependent upon } \\
\text { individual faculty. }\end{array}$ & $\begin{array}{l}\text { Specialization in International } \\
\text { Social Work is offered and } \\
\text { well developed with sound } \\
\text { content or proposed and in } \\
\text { planning stage. Faculty is } \\
\text { excellent and highly } \\
\text { motivated. Hiring of faculty } \\
\text { with interest in international } \\
\text { research or program } \\
\text { development. }\end{array}$ & $\begin{array}{l}\text { Specialization in International } \\
\text { Social Work is offered and } \\
\text { well developed with sound } \\
\text { content. Faculty is excellent } \\
\text { and highly motivated. Hiring } \\
\text { of faculty with interest in } \\
\text { international research or } \\
\text { program development. } \\
\text { Faculty receives ongoing } \\
\text { training and experience at } \\
\text { the international level. }\end{array}$ \\
\hline 1 & $3 \quad 4$ & 6 \\
\hline 2 & 5 & 7 \\
\hline
\end{tabular}

5. Practicum Abroad Offered as Part of International Social Work

\begin{tabular}{|c|c|c|}
\hline Unacceptable & Acceptable & Exemplary \\
\hline $\begin{array}{l}\text { Practicum abroad is not } \\
\text { offered or not offered on a } \\
\text { regular basis. Obstacles to } \\
\text { offering and arranging } \\
\text { practicum abroad. }\end{array}$ & $\begin{array}{l}\text { Practicum abroad is offered } \\
\text { but underdeveloped. } \\
\text { Relationships being } \\
\text { developed with universities } \\
\text { abroad. }\end{array}$ & $\begin{array}{l}\text { Practicum abroad is offered. } \\
\text { Relationships developed with } \\
\text { universities abroad. Clear } \\
\text { field contracts negotiated } \\
\text { and students' learning goals } \\
\text { clearly defined and } \\
\text { international manual } \\
\text { developed. Students } \\
\text { prepare a semester in } \\
\text { advance. }\end{array}$ \\
\hline 2 & 4 & 6 \\
\hline
\end{tabular}

\section{Technology Used to Enhance International Social Work Content}

\begin{tabular}{|c|l|l|}
\hline \multicolumn{1}{|c|}{ Unacceptable } & \multicolumn{1}{|c|}{ Acceptable } & \multicolumn{1}{c|}{ Exemplary } \\
\hline $\begin{array}{l}\text { Technology is not used to } \\
\text { Whance International Social } \\
\text { upon individual faculty. }\end{array}$ & $\begin{array}{l}\text { Technology is used to } \\
\text { enhance International Social } \\
\text { Work content Interactive } \\
\text { course software allows for } \\
\text { intra-class discussions. } \\
\text { Students on field } \\
\text { experiences use email to } \\
\text { send weekly journals to field } \\
\text { supervisor. }\end{array}$ & $\begin{array}{l}\text { Technology is used to } \\
\text { enhance International Social } \\
\text { Work content. Interactive } \\
\text { course software allows for } \\
\text { intra-class discussions. } \\
\text { Students on field } \\
\text { experiences use email to } \\
\text { send weekly journals to field } \\
\text { supervisor. Use of } \\
\text { contemporary interactive } \\
\text { course software provides for } \\
\text { guest lecturers from other } \\
\text { countries and links to } \\
\text { classrooms in other countries } \\
\text { for cross-national } \\
\text { discussions. }\end{array}$ \\
\hline 2 & 3 & 6 \\
\hline 1 & 4 & 5 \\
\hline
\end{tabular}


7. International Social Work Infused Into Social Work Curriculum

\begin{tabular}{|c|c|c|}
\hline Unacceptable & Acceptable & Exemplary \\
\hline $\begin{array}{l}\text { International social work is } \\
\text { not infused or dependent } \\
\text { upon individual faculty }\end{array}$ & $\begin{array}{l}\text { International Social Work is } \\
\text { infused in some of the social } \\
\text { work curriculum through } \\
\text { elective, formal course, or } \\
\text { policy courses. Infusion } \\
\text { needs further development. }\end{array}$ & $\begin{array}{l}\text { International Social Work is } \\
\text { infused across the social } \\
\text { work curriculum. } \\
\text { International content } \\
\text { constantly reviewed and } \\
\text { updated. Comparative } \\
\text { content cuts across all } \\
\text { courses so that all students } \\
\text { are exposed to international } \\
\text { social work. }\end{array}$ \\
\hline 2 & 3 & 67 \\
\hline
\end{tabular}

8. Diversity Infused Into Social Work Curriculum

\begin{tabular}{|c|c|c|}
\hline Unacceptable & Acceptable & Exemplary \\
\hline $\begin{array}{l}\text { Infusion not mandatory and } \\
\text { diversity is not infused or } \\
\text { inconsistent and dependent } \\
\text { upon individual faculty. }\end{array}$ & $\begin{array}{l}\text { Diversity infused into social } \\
\text { work curriculum to some } \\
\text { degree through course } \\
\text { objectives with readings } \\
\text { and/or assignments which } \\
\text { require students to read, } \\
\text { research, and reflect. } \\
\text { Specified educational } \\
\text { objectives. Infusion needs } \\
\text { further development }\end{array}$ & $\begin{array}{l}\text { Diversity infused into social } \\
\text { work curriculum and in core } \\
\text { courses as an essential } \\
\text { component through readings } \\
\text { and/or assignments which } \\
\text { require students to read, } \\
\text { research, and reflect. Focus } \\
\text { on multicultural practice } \\
\text { which includes interacting } \\
\text { effectively with individuals } \\
\text { from other cultures. } \\
\text { Emphasis on valuing } \\
\text { differences used to sensitize } \\
\text { student to other } \\
\text { perspectives. Specified } \\
\text { educational objectives. }\end{array}$ \\
\hline 2 & 4 & 67 \\
\hline
\end{tabular}

9. Populations at Risk/Economic Justice Infused Into Social Work Curriculum

\begin{tabular}{|c|c|c|}
\hline Unacceptable & Acceptable & Exemplary \\
\hline $\begin{array}{l}\text { Infusion not mandatory and } \\
\text { populations at risk/economic } \\
\text { justice not infused or } \\
\text { inconsistent and dependent } \\
\text { upon individual faculty. }\end{array}$ & $\begin{array}{l}\text { Infused into social work } \\
\text { curriculum to some degree } \\
\text { through readings and/or } \\
\text { assignments which require } \\
\text { students to read, research, } \\
\text { and reflect. Infusion needs } \\
\text { further development. } \\
\text { Specified educational } \\
\text { objectives. }\end{array}$ & $\begin{array}{l}\text { Infused into entire social } \\
\text { work curriculum through } \\
\text { readings and/or assignments } \\
\text { which require students to } \\
\text { read, research, and reflect. } \\
\text { Focus upon global issues } \\
\text { including poverty, human } \\
\text { rights violations, pandemic } \\
\text { illnesses, immigration, and } \\
\text { examination of welfare state } \\
\text { of various nations in relation } \\
\text { to United States. Specified } \\
\text { educational objectives. }\end{array}$ \\
\hline 2 & 4 & 6 \\
\hline
\end{tabular}


10. Human Behavior in the Social Environment Infused Into Social Work Curriculum

\begin{tabular}{|c|c|c|}
\hline Unacceptable & Acceptable & Exemplary \\
\hline $\begin{array}{l}\text { Infusion not mandatory and } \\
\text { HBSE not infused or } \\
\text { inconsistent and dependent } \\
\text { upon individual faculty. }\end{array}$ & $\begin{array}{l}\text { Infused into social work } \\
\text { curriculum to some degree } \\
\text { through readings and/or } \\
\text { assignments which require } \\
\text { students to read, research, } \\
\text { and reflect. Infusion needs } \\
\text { further development. } \\
\text { Specified educational } \\
\text { objectives. }\end{array}$ & $\begin{array}{l}\text { Infused into entire social } \\
\text { work curriculum through } \\
\text { readings and/or assignments } \\
\text { which require students to } \\
\text { read, research, and reflect. . } \\
\text { Focus upon cultural } \\
\text { differences in the } \\
\text { developmental cycle across } \\
\text { each system level from } \\
\text { individual to global with } \\
\text { emphasis on how cultural } \\
\text { differences impact human } \\
\text { behavior. Specified } \\
\text { educational objectives. }\end{array}$ \\
\hline 2 & 4 & 6 \\
\hline
\end{tabular}

\section{Social Welfare Policy Infused Into Social Work Curriculum}

\begin{tabular}{|c|c|c|}
\hline Unacceptable & Acceptable & Exemplary \\
\hline $\begin{array}{l}\text { Infusion not mandatory and } \\
\text { Social Welfare Policy not } \\
\text { infused or inconsistent and } \\
\text { dependent upon individual } \\
\text { faculty. }\end{array}$ & $\begin{array}{l}\text { Infused into social work } \\
\text { curriculum to some degree } \\
\text { through readings and/or } \\
\text { assignments which require } \\
\text { students to read, research, } \\
\text { and reflect. Infusion needs } \\
\text { further development. } \\
\text { Specified educational } \\
\text { objectives. }\end{array}$ & $\begin{array}{l}\text { Infused into entire social } \\
\text { work curriculum through } \\
\text { readings and/or assignments } \\
\text { which require students to } \\
\text { read, research, and reflect. } \\
\text { International models of social } \\
\text { welfare presented and } \\
\text { comparative policy analysis } \\
\text { conducted. Specified } \\
\text { educational objectives. }\end{array}$ \\
\hline 1 & 3 & 6 \\
\hline
\end{tabular}

12. Cross-Cultural Knowledge and Skills Infused Into Social Work Curriculum

\begin{tabular}{|c|c|c|}
\hline Unacceptable & Acceptable & Exemplary \\
\hline $\begin{array}{l}\text { Infusion not mandatory and } \\
\text { Cross-Cultural Knowledge } \\
\text { and Skills not infused or } \\
\text { inconsistent and dependent } \\
\text { upon individual faculty. }\end{array}$ & $\begin{array}{l}\text { Infused into social work } \\
\text { curriculum to some degree } \\
\text { through readings and/or } \\
\text { assignments which require } \\
\text { students to read, research, } \\
\text { and reflect. Infusion needs } \\
\text { further development. } \\
\text { Specified educational } \\
\text { objectives. }\end{array}$ & $\begin{array}{l}\text { Infused into entire social } \\
\text { work curriculum through } \\
\text { readings and/or assignments } \\
\text { which require students to } \\
\text { read, research, and reflect. } \\
\text { Role playing and problem } \\
\text { solving situations in } \\
\text { classroom experience } \\
\text { provide for self-awareness } \\
\text { and skill building. } \\
\text { Certificates awarded for } \\
\text { acquiring skills in working } \\
\text { with different populations. }\end{array}$ \\
\hline 2 & 4 & 6 \\
\hline
\end{tabular}




\begin{tabular}{|c|c|c|}
\hline Unacceptable & Acceptable & Exemplary \\
\hline $\begin{array}{l}\text { Infusion not mandatory and } \\
\text { Values and Ethics not } \\
\text { infused or inconsistent and } \\
\text { dependent upon individual } \\
\text { faculty. }\end{array}$ & $\begin{array}{l}\text { Infused into social work } \\
\text { curriculum to some degree } \\
\text { through readings and/or } \\
\text { assignments which require } \\
\text { students to read, research, } \\
\text { and reflect. Infusion needs } \\
\text { further development. } \\
\text { Specified educational } \\
\text { objectives. }\end{array}$ & $\begin{array}{l}\text { Infused into entire social } \\
\text { work curriculum through } \\
\text { readings and/or assignments } \\
\text { which require students to } \\
\text { read, research, and reflect. } \\
\text { Focus on human rights and } \\
\text { social justice. Discussion of } \\
\text { the relative nature of values } \\
\text { in different cultures. } \\
\text { Incorporation of various } \\
\text { codes of ethics (i.e. NASW, } \\
\text { IFSW, United Nations } \\
\text { Human Rights) studying } \\
\text { underlying principles and } \\
\text { identification of ethical } \\
\text { dilemmas. Specified } \\
\text { educational objectives. }\end{array}$ \\
\hline 1 & 4 & 6 \\
\hline
\end{tabular}

14. Social Problems Infused Into Social Work Curriculum

\begin{tabular}{|c|c|c|}
\hline Unacceptable & Acceptable & Exemplary \\
\hline $\begin{array}{l}\text { Infusion not mandatory and } \\
\text { Social Problems not infused } \\
\text { or dependent upon individual } \\
\text { faculty. }\end{array}$ & $\begin{array}{l}\text { Infused into social work } \\
\text { curriculum to some degree } \\
\text { through readings and/or } \\
\text { assignments which require } \\
\text { students to read, research, } \\
\text { and reflect. Infusion needs } \\
\text { further development. } \\
\text { Specified educational } \\
\text { objectives. }\end{array}$ & $\begin{array}{l}\text { Infused into entire social } \\
\text { work curriculum through } \\
\text { readings and/or assignments } \\
\text { which require students to } \\
\text { read, research, and reflect. } \\
\text { Focus on social problems } \\
\text { that are both the same and } \\
\text { different in other countries } \\
\text { utilized as learning tool for } \\
\text { students to critique. } \\
\text { Utilization of outside } \\
\text { resources to update classes } \\
\text { to the extent and nature of } \\
\text { shifting social problems } \\
\text { globally. Specified } \\
\text { educational objectives. }\end{array}$ \\
\hline 2 & 4 & 6 \\
\hline
\end{tabular}


15. Human Oppression Infused Into Social Work Curriculum

\begin{tabular}{|l|l|l|}
\hline \multicolumn{1}{|c|}{ Unacceptable } & \multicolumn{1}{|c|}{ Acceptable } & \multicolumn{1}{c|}{ Exemplary } \\
\hline $\begin{array}{l}\text { Infusion not mandatory and } \\
\text { infused or dependent upon } \\
\text { individual faculty. }\end{array}$ & $\begin{array}{l}\text { Infused into social work } \\
\text { curriculum to some degree } \\
\text { through readings and/or } \\
\text { assignments which require } \\
\text { students to read, research, } \\
\text { and reflect. Specified } \\
\text { educational objectives. }\end{array}$ & $\begin{array}{l}\text { Infused into entire social } \\
\text { work curriculum through } \\
\text { readings and/or assignments } \\
\text { which require students to } \\
\text { read, research, and reflect. } \\
\text { Focus on role of oppression } \\
\text { in practice and impact on } \\
\text { populations. Outside } \\
\text { resources are brought into } \\
\text { classroom (i.e. UN } \\
\text { Convention on the } \\
\text { Elimination of All Forms of } \\
\text { Racial Discrimination) for } \\
\text { discussion and comparative } \\
\text { analysis. Specified } \\
\text { educational objectives. }\end{array}$ \\
\hline 2 & 3 & 5 \\
\hline 1 & 4 & 6 \\
\hline
\end{tabular}

\section{Limitations of the Study}

There were several limitations to this study. The sample for this study was self-selected. Self-selection occurs when the entities in the sample are given a choice to participate. If a set of members in the sample decides not to participate, it reduces the ability of the results to generalize to the entire population. Although the results of this study are consistent with the literature and may be representative of the programs/schools of social work that participated in the survey, they are only generalizable to other CSWE approved schools of social work with master's degree programs.

The survey used was a self-reporting instrument that had not been piloted and reliability and validity had not been established. The participants in the survey provided information regarding their international social work programs and were given the opportunity to provide reasons for their ratings. The possibility exists that non-respondents did not have an international component 
to their social work curriculum. Those who responded with an interest in international social work may have participated more fully.

Terminology was another limitation of this research. Terms that have been used to define various aspects of international social work have often been used interchangeably. An example was in the use of the words "abroad" and "overseas" in the survey. Several respondents reported that they had difficulty responding because they used the term "abroad" to mean anywhere beyond their own country and "overseas" to mean countries across an ocean from their own country.

\section{Summary}

If United States social workers are to be successful in expanding their global horizons, then international social work cannot be isolated within the profession. International social work enables U.S. social workers to see the value of international exchanges in gaining knowledge into approaches to social work from other perspectives. In seeing the value of different approaches, it assists U.S. social workers to adapt their practice in the United States to other cultures and peoples. We cannot assume that our Western paradigm of knowledge and expertise is universally applicable. The importance of educating social workers who are internationally competent is acknowledged and valued by the social work profession. The quality of international social work education and curriculum continues to be challenged. If social workers are not educated to work within an international social work paradigm, there can be profound and 
unwanted consequences for students, their abilities to engage in social work practice, and for the profession of social work itself. 


\section{REFERENCES}

Abbott, A. (1990). Measuring social work values: A cross-cultural challenge for practice, International Social Work, 42(4),: 455-470.

Asamoah, Y. (1997, Spring/Summer). Ending the international-domestic dichotomy: New approaches to a global curriculum for the millennium, Journal of Social Work Education, 33(2), 389-401.

Barnett, R. V. (1991). Administrator's perceptions of effectiveness of international Studies and programs in institutions of higher education. (Doctoral Dissertation, University of Florida, 1991). Proquest Digital Dissertations.

Bogo, M., \& Herington, W. (1988). Consultation in social work education in the international context, International Social Work, 31(4), 302-316.

Boyle, D., \& Nackerud, L., \& Kirkpatrick, A. (1999). The road less traveled: Cross-Cultural, international experiential learning, International Social Work, 42(2), 201-204.

Broadfoot, P. (2000). Comparative education for the $21^{\text {st }}$ century: Retrospect and prospect. Comparative Education, 357-371.

Campfens, L. (2000). Partnerships in international social development: Evolution in practice and concept. International Social Work, 39(2), 201-223. 
Carmines, E.G., \& Zeller, r. A. (1979). Reliability and validity assessment. London: Sage Publications.

Chambliss, D. L., Baker, M.J., Baucom, D.H., Beautler, L.E., Calhoun, K.S., Crits-Christoph, P., Daiuto, A., DeRubeis, R., Detweiler, J., Haaga, D.A., Johnson, S.B., McCurry, S., Mueser, K.T., Pope, K.S., Sanderson, W.C., Shohan, V., Stickle, T., Williams, D.A., \& Woody, S.R., (1998). An update on empirically validated therapies, II. Clinical Psychologist, 51(1), 3-16.

Constable, R., \& Mehta, V. (1994). Changing horizons in education for social work and human services in Eastern Europe. Chicago: Lyceum.

Council on Social Work Education. (1994). Curriculum policy statement for Master's degree programs in social work education. In Handbook for accreditation standards and procedures (pp. 134-144). Alexandria, VA.

Council on Social Work Education. (2002). Curriculum policy statement for Master's degree programs in social work education. [On-line]. Retrieved on September 7, 2004 from the World Wide Web at site address: http://www.cswe.org

Davies, L. (2000). The future of education: International perspectives, Education Review 52(2), 125-131.

DeVos, A.S. (1998). Research at grass roots: A primer for the caring professions. Pretoria, South Africa: J. L. Schaik.

Dillman, D. (2000). Mail and internet surveys: The tailored design method. John Wiley \& Sons, Inc. 
Dominelli, L. (1993). International social development and social work: A feminist perspective. In M.C. Hokenstad \& J. Midgley (Eds.). Issues in international social work: Global challenges for a new century (pp.74-91). NASW Press, Washington, D.C.

Donaldson, T. (1996). Values in tension: Ethics away from home, Harvard Business Review, 74(5), 48-62.

Donnelly, J. (1984). Cultural relativism and universal human rights, Human Rights Quarterly, 6, 400-419.

Estes, R. (1992). Internationalizing social work education: A guide to resources for a new century, Philadelphia.

Faul, A.C. (1995). Scale development in social work. (Doctoral dissertation, Rand Africaans University, 1995).

Gambrill, E. (1999). Evidence-based practice: An alternative to authoritybased practice, Families in Society, 80(4), 341-350.

Garber, R. (1997). Social work education in an international context: Current trends and future directions. In M.C. Hokenstad \& J. Midgely (Eds.). Issues in intemational social work: Global challenge for a new Century (pp. 159-171). NASW Press, Washington, D.C.

Garland, D., \& Escobar, D. (1988). Education for a cross-cultural social work practice, Joumal of Social Work Education 24(3), 229-241.

Goldstein, H. (1986). Education for social work practice: A cognitive, crosscultural approach, International Social Work 29, 149-164.

Gray, M., \& Simpson, B. (1988). Developmental social work education: A field 
example, International Social Work 41(2) 227-237.

Harris, R. (1990). Beyond rhetoric: A challenge for international social work, International Social Work 33(3), 203-212.

Healy, L. (1988). Curriculum building in international social work: Toward preparing professionals for the global age, Journal of Social Work Education 24(3), 221-228.

Healy, L. M., \& Asamoah, Y. W. (Eds). 1997. Global perspectives in social work education: A collection of course outlines on international aspects of social work. Alexandria, VA: Council on Social Work Education.

Healy, L. (1999). International social work curriculum in historical perspective. In C. Ramanathan \& R. Link (Eds.), All our futures: Principles and resources for social work practice in a global era (pp. 14-29). Belmont, CA: Brooks/ Cole.

Healy, L. (2001). International social work: Professional action in an interdependent world, New York, NY: Oxford University Press.

Healy, L. (2003, April). Internationalizing social work curriculum. Paper presented at the Wisconsin Council of Social Work Education Workshop. September 4, 2004, from Connecticutt University, Center for international social work studies Web site: http://www.ssw.uconn.edu Hokenstad, M. C., \& Midgley, J. (Eds.), (1997). Issues in international social work: Global challenges for a new century. NASW Press.

Horncastle, J. (1994). Training for international social work: Initial experiences, International Social Work 31(4), 309-318. 
Horne, B.E. (1999). An assessment package for a life counseling model.

Doctoral Dissertation Rand Afrikaans University.

Huber, R., Borders, K., Badrak, K., Netting, F.E., \& Nelson, H. W. (2001, April).

National standards for the long-term care ombudsman program and a tool to assess compliance: The Huber Badrak Borders Scale. The Gerontologist 41(2), 264-271.

International Federation of Social Workers (1994), International Code of Ethics for the Professional Social Worker, Oslo, Norway. International Federation of Social Workers (2000), International Federation of Social Workers: Definition of Social Work. [On-line]. Retrieved on June 26, 2001 from the World Wide Web at site address:

http://www.ifsw.org/Publications/4.6e.pub.html

Jayarantne, S., \& Levy, R.L. (1979). Empirical clinical practice. New York:

Columbia University Press.

Johnson, H. (1996). International activity in undergraduate social work education in the United States, International Social Work 31(4), 189-19.

Lewis, L.S. \& Altbach, P.G. (1996). The professoriate in international perspective. Academe, Bulletin of the AAUP, 82(3), 29-33.

Link, R. (1999). Infusing global perspectives into social work values and ethics. In C.S. Ramanathan \& R. J. Link (Eds.). All our futures: Principles and resources for social work practice in a global era (pp. 69-93). Belmont, CA.: Brooks Cole/Wadsworth.

Lowenberg, F.M., Golgoff, R., \& Harrington, D. (2000). Ethical decisions for 
social work practice, Sixth Edition, Itasca, IL: Peacock.

Mayer, A. E. (1995), Cultural particularism as a bar to women's rights:

Reflections on the Middle Eastern experience. In J. Peters \& A. Wolper

(Eds.). Women's rights, human rights: International feminist perspectives (pp. 176-188). New York: Routledge.

Midgley, J. (1990). Social development and multicultural social work, Social Work 35(4), 295-301.

Mullen, E.J. (2002, July). Evidence-based social work-theory and practice: Historical and reflective perspective. Paper presented at the $4^{\text {th }}$ International Conference on Evaluation for Practice, University of Tampere, Tampere, Finland. Retrieved April 4, 2004, from Faculty of Education Web site: http://education.ntu.ac.uk/research

Nagy, G., \& Falk, D. (2000). Dilemmas in international social work and crosscultural social work education, International Social Work 43(1), 49-60.

Nunnally, J. C., \& Bernstein, I. H. (1994). Psychometric theory. New York: McGraw-Hill.

Padgett, D. K. (1998). Qualitative methods in social work research: Challenges and rewards. Thousand Oaks, CA: Sage Publications.

Pawar, M. (2000). Social development content in courses of Australian social work schools, International Social Work 43(3), 49-60.

Rubin, A. \& Babbie, E. (1997). Research methods for social work ( $3^{\text {rd }}$ ed.), Brooks/Cole.

Rubin, A, \& Babbie, E. (2001). Research methods for social work ( $4^{\text {th }}$ ed.), 
Belmont, CA: Wadsworth.

Sachdev, P. (1997). Cultural sensitivity training through experiential learning. A participatory demonstration field education project, International Social Work 40, 7-25.

Sackett, D. (1996). Evidence-based medicine-what it is and what it isn't.

Retrieved April 4, 2004, from http://www.cebn.net/ebm is isnt.asp

Siegel, D. (1984). Defining empirically based practice, Social Work 29(4), 325337.

Singleton, R. A., \& Straits, B. C. (1999). Approaches to social research ( $3^{\text {rd }}$ ed.). New York, NY: Oxford University Press.

Skolnick, L., Wayne, J., \& Raskin, M. (1999). A worldwide view of field education structures and curricula, International Social Work 42(4), 471-483.

Theyr, B.A., \& Wodarski, J.S. (Eds.). (1998). Handbook for empirical social work Practice: Mental disorders (Vol.1). New York: John Wiley.

Wilson, A. (2000). Enlarging our global perspective: Lessons from Ghana, The Social Studies 91(5), 197-201.

Woody, S.R., \& Sanderson, W.C. (1998). Manuals for empirically based support treatments: 1998 update. The Clinical Psychologist, 51(1), 17-21.

Younes, M. (1998). The gatekeeping dilemma in undergraduate social work programs: Collision of ideal and reality, International Social Work 41(2), 145-153. 


\section{Current Status of International Social Work}

The purpose of this survey is to learn the current status of international social work within the social work curriculum.

YOUR PARTICIPATION IS VERY IMPORTANT TO US!

\section{Demographic Information}

Please provide us with some basic information about your program.

Q1: 1. Is your college/university?

Please choose only one of the following:

Public

Private,sectarian

Private

Q2: 2. How many students are enrolled in your university? (full and parttime)

Please write your answer here:

Q3: 3. How many students are enrolled in your social work program? (all degrees combined)

Please write your answer here:

Q4: 4. What type of degree programs are offered?

Please choose all that apply:

BSW

MSW

$\mathrm{PhD}$

Q5: 5. Type of setting for college/university?

Please choose only one of the following:

rural

suburban 
urban

Q6: 6. Number of social work full-time tenure track faculty?

Please write your answer here:

Q7: 7. Number of full-time faculty with an interest in international social work?

Please write your answer here:

Format of International Social Work Content in Curriculum

Please rate the format and quality of the International Social Work Content in your curriculum by answering the following questions.

Q8A: 8. International social work is covered in your program's social work curriculum, either through infusing into existing classes or offered as a specific course?

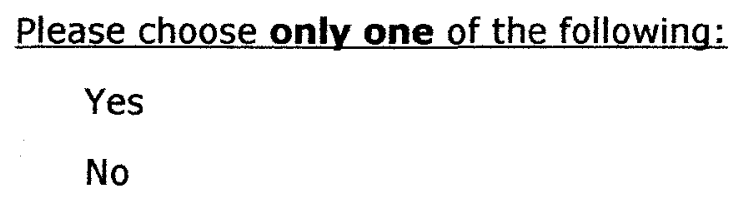

[Only answer this question if you answered 'Yes' to question 'Q8A ']

Q8B: Please rate the quality of the international social work content in your curriculum

Please choose the appropriate response for each item:

$\begin{array}{lllllll}\text { Unacceptable } & 2 & 3 & \text { Essential } & 5 & 6 & \text { Exemplary }\end{array}$

Answer

[Only answer this question if you answered 'Yes' to question 'Q8A ']

Q8C: Reasons for rating

Please write your answer here:

[Only answer this question if you answered 'No' to question 'Q8A ']

Q8D: At the current time, international social work is not a component of the social work curriculum but is in the process of being included. 


\section{Please choose only one of the following:}

Yes

No

[Only answer this question if you answered 'No' to question 'Q8A' and if you answered 'Yes' to question 'Q8D ']

Q8E: If yes, please explain how it will be included with the current curriculum.

Please write your answer here:

[Only answer this question if you answered 'Yes' to question 'Q8A ']

Q9A: 9. International social work is offered as a specific core course.

Please choose only one of the following:

Yes

No

[Only answer this question if you answered 'Yes' to question 'Q8A ' and if you answered 'Yes' to question 'Q9A ']

Q9B: Please rate the quality of the specific core course.

Please choose the appropriate response for each item:

$\begin{array}{lllllll}\text { Unacceptable } & 2 & 3 & \text { Essential } & 5 & 6 & \text { Exemplary }\end{array}$

Answer

[Only answer this question if you answered 'Yes' to question 'Q8A ' and if you answered 'Yes' to question 'Q9A ']

Q9C: Reasons for rating

Please write your answer here: 
[Only answer this question if you answered 'Yes' to question 'Q8A ']

Q10A: 10. International social work is offered as an elective organized around various international social work issues (does include overseas field trip).

Please choose only one of the following:

Yes

No

[Only answer this question if you answered 'Yes' to question 'Q8A ' and if you answered 'Yes' to question 'Q10A ']

Q10B: Please rate the quality of the elective.

Please choose the appropriate response for each item:

$\begin{array}{lllllll}\text { Unacceptable } & 2 & 3 & \text { Essential } & 5 & 6 & \text { Exemplary }\end{array}$

Answer

[Only answer this question if you answered 'Yes' to question 'Q8A ' and if you answered 'Yes' to question 'Q10A ']

Q10C: Reasons for rating

Please write your answer here:

[Only answer this question if you answered 'Yes' to question 'Q8A ']

Q11A: 11. International social work is offered as an elective organized around various international social work issues (no overseas field trip).

Please choose only one of the following:

Yes

No

[Only answer this question if you answered 'Yes' to question 'Q8A ' and if you answered 'Yes' to question 'Q11A ']

Q11B: Please rate the quality of the elective.

Please choose the appropriate response for each item:

$\begin{array}{lllllll}\text { Unacceptable } & 2 & 3 & \text { Essential } & 5 & 6 & \text { Exemplary }\end{array}$

Answer

IOnly answer this question if you answered 'Yes' to question 'O8A ' and if you 


\section{answered 'Yes' to question 'Q11A ']}

\section{Q11C: Reasons for rating}

Please write your answer here:

[Only answer this question if you answered 'Yes' to question 'Q8A ']

Q12A: 12. International social work is offered as a specialization (separate tract) within the social work curriculum, without any infusion into existing social work courses.

Please choose only one of the following:

$$
\begin{aligned}
& \text { Yes } \\
& \text { No }
\end{aligned}
$$

[Only answer this question if you answered 'Yes' to question 'Q8A ' and if you answered 'Yes' to question 'Q12A ']

Q12B: Please rate the quality of the specialization.

Please choose the appropriate response for each item:

$\begin{array}{lllllll}\text { Unacceptable } & 2 & 3 & \text { Essential } & 5 & 6 & \text { Exemplary }\end{array}$

Answer

[Only answer this question if you answered 'Yes' to question 'Q8A' and if you answered 'Yes' to question 'Q12A ']

\section{Q12C: Reasons for rating}

Please write your answer here:

[Only answer this question if you answered 'Yes' to question 'Q8A ']

Q13A: 13. International social work is offered as a specialization (separate tract) and also infused into existing social work courses.

Please choose only one of the following: 
[Only answer this question if you answered 'Yes' to question 'Q8A ' and if you answered 'Yes' to question 'Q13A ']

Q13B: Please rate the quality of the specialization and the infusion.

Please choose the appropriate response for each item:

$\begin{array}{lllllll}\text { Unacceptable } & 2 & 3 & \text { Essential } & 5 & 6 & \text { Exemplary }\end{array}$

Answer

[Only answer this question if you answered 'Yes' to question 'Q8A ' and if you answered 'Yes' to question 'Q13A ']

Q13C: Reasons for rating

Please write your answer here:

[Only answer this question if you answered 'Yes' to question 'Q8A ']

Q14A: 14. International social work is limited to overseas field trips within the social work curriculum, without any course specific requirements.

Please choose only one of the following:

Yes

No

[Only answer this question if you answered 'Yes' to question 'Q8A ' and if you answered 'Yes' to question 'Q14A ']

Q14B: Please rate the quality of the overseas field trips.

Please choose the appropriate response for each item:

$\begin{array}{lllllll}\text { Unacceptable } & 2 & 3 & \text { Essential } & 5 & 6 & \text { Exemplary }\end{array}$

Answer

[Only answer this question if you answered 'Yes' to question 'Q8A ' and if you answered 'Yes' to question 'Q14A ']

Q14C: Reasons for rating

Please write your answer here: 
[Only answer this question if you answered 'Yes' to question 'Q8A ']

Q15A: 15. International social work is offered as a core course, as an elective, and infused into existing social work courses.

Please choose only one of the following:

$$
\begin{aligned}
& \text { Yes } \\
& \text { No }
\end{aligned}
$$

[Only answer this question if you answered 'Yes' to question 'Q8A ' and if you answered 'Yes' to question 'Q15A ']

Q15B: Please rate the quality.

Please choose the appropriate response for each item:

$\begin{array}{lllllll}\text { Unacceptable } & 2 & 3 & \text { Essential } & 5 & 6 & \text { Exemplary }\end{array}$

Answer

[Only answer this question if you answered 'Yes' to question 'Q8A ' and if you answered 'Yes' to question 'Q15A ']

\section{Q15C: Reasons for rating}

Please write your answer here:

[Only answer this question if you answered 'Yes' to question 'Q8A ']

Q16A: 16. An overseas practicum is offered as part of your international social work program.

Please choose only one of the following:

$$
\begin{aligned}
& \text { Yes } \\
& \text { No }
\end{aligned}
$$

rOnlv answer this question if vou answered 'Yes' to question 'O8A ' and if vou 
answered 'Yes' to question 'Q16A ']

Q16B: Please rate the quality of the practicum.

Please choose the appropriate response for each item:

Answer

[Only answer this question if you answered 'Yes' to question 'Q8A' and if you answered 'Yes' to question 'Q16A ']

Q16C: Reasons for rating

Please write your answer here:

[Only answer this question if you answered 'Yes' to question 'Q8A ' and if you answered 'Yes' to question 'Q16A ']

Q16D: If yes, please list the countries available for student practicum. Please write your answer here:

[Only answer this question if you answered 'Yes' to question 'Q8A ']

Q17A: 17. International social work is not offered as a separate course or tract but is infused into existing social work courses.

Please choose only one of the following:

$$
\text { Yes }
$$

No

[Only answer this question if you answered 'Yes' to question 'Q8A' and if you answered 'Yes' to question 'Q17A ']

Q17B: Please rate the quality of the infusion.

Please choose the appropriate response for each item: 
Answer

[Only answer this question if you answered 'Yes' to question 'Q8A ' and if you answered 'Yes' to question 'Q17A ']

\section{Q17C: Reasons for rating}

Please write your answer here:

[Only answer this question if you answered 'Yes' to question 'Q8A ' and if you answered 'Yes' to question 'Q17A ']

Q17D: If yes, please list the courses that infuse international social work.

Please write your answer here:

[Only answer this question if you answered 'Yes' to question 'Q8A ']

Q18A: 18. Technology is used to enhance international social work curriculum (e.g. computer use for communication with social work students in other countries)

Please choose only one of the following:

$$
\text { Yes }
$$

No

[Only answer this question if you answered 'Yes' to question 'Q8A ' and if you answered 'Yes' to question 'Q18A ']

Q18B: Please rate the quality of the use of technology.

Please choose the appropriate response for each item: 
[Only answer this question if you answered 'Yes' to question 'Q8A ' and if you answered 'Yes' to question 'Q18A ']

\section{Q18C: Reasons for rating}

Please write your answer here:

\section{Infusion of International Social Work Content}

If you infuse international social work content into existing courses, please answer the following questions.

[Only answer this question if you answered 'Yes' to question 'Q8A ']

Q19A: 19. Diversity as it applies to international social work is infused into existing social work courses.

Please choose only one of the following:

\section{Yes}

No

[Only answer this question if you answered 'Yes' to question 'Q8A ' and if you answered 'Yes' to question 'Q19A ']

Q19B: Please rate the quality of the infusion.

Please choose the appropriate response for each item:

$\begin{array}{lllllll}\text { Unacceptable } & 2 & 3 & \text { Essential } & 5 & 6 & \text { Exemplary }\end{array}$

Answer

[Only answer this question if you answered 'Yes' to question 'Q8A' and if you answered 'Yes' to question 'Q19A ']

Q19C: Please explain how diversity is infused and the reasons for your rating.

Please write your answer here:

[Only answer this question if you answered 'Yes' to question 'Q8A '] 
Q20A: 20. Populations at risk/social and economic justice as it applies to international social work is infused into existing social work courses.

Please choose only one of the following:

Yes

No

[Only answer this question if you answered 'Yes' to question 'Q8A ' and if you answered 'Yes' to question 'Q20A ']

Q20B: Please rate the quality of the infusion.

Please choose the appropriate response for each item:

$\begin{array}{lllllll}\text { Unacceptable } & 2 & 3 & \text { Essential } & 5 & 6 & \text { Exemplary }\end{array}$

Answer

[Only answer this question if you answered 'Yes' to question 'Q8A ' and if you answered 'Yes' to question 'Q20A ']

Q20C: Please explain how populations at risk/social and economic justice are infused and reasons for your rating.

Please write your answer here:

[Only answer this question if you answered 'Yes' to question 'Q8A ']

Q21A: 21. Human behavior in the social environment as it applies to international social work is infused into existing social work courses.

Please choose only one of the following:

Yes

No

[Only answer this question if you answered 'Yes' to question 'Q8A ' and if you answered 'Yes' to question 'Q21A ']

Q21B: Please rate the quality of the infusion.

Please choose the appropriate response for each item:

$\begin{array}{llllllll}\text { Unacceptable } & 2 & 3 & \text { Essential } & 5 & 6 & \text { Exemplary }\end{array}$

Answer

[Only answer this question if you answered 'Yes' to question 'Q8A' and if you answered 'Yes' to question 'Q21A '] 
Q21C: Please explain how human behavior in the social environment is infused and reasons for your rating.

Please write your answer here:

[Only answer this question if you answered 'Yes' to question 'Q8A ']

Q22A: 22. Social welfare policy and services as they apply to international social work are infused into existing social work courses.

Please choose only one of the following:

Yes

No

[Only answer this question if you answered 'Yes' to question 'Q8A ' and if you answered 'Yes' to question 'Q22A ']

Q22B: Please rate the quality of the infusion.

Please choose the appropriate response for each item:

$\begin{array}{lllllll}\text { Unacceptable } & 2 & 3 & \text { Essential } & 5 & 6 & \text { Exemplary }\end{array}$

Answer

[Only answer this question if you answered 'Yes' to question 'Q8A' and if you answered 'Yes' to question 'Q22A ']

Q22C: Please explain how social welfare policy and service is infused and reasons for your rating.

Please write your answer here:

[Only answer this question if you answered 'Yes' to question 'Q8A ']

Q23A: 23. Cross-cultural knowledge and skill as they apply to international social work are infused into existing social work courses.

Please choose only one of the following:

Yes 
[Only answer this question if you answered 'Yes' to question 'Q8A ' and if you answered 'Yes' to question 'Q23A ']

Q23B: Please rate the quality of the infusion.

Please choose the appropriate response for each item:

$\begin{array}{lllllll}\text { Unacceptable } & 2 & 3 & \text { Essential } & 5 & 6 & \text { Exemplary }\end{array}$

Answer

[Only answer this question if you answered 'Yes' to question 'Q8A ' and if you answered 'Yes' to question 'Q23A ']

Q23C: Please explain how cross-cultural knowledge and skill are infused and reasons for your rating.

Please write your answer here:

[Only answer this question if you answered 'Yes' to question 'Q8A ']

Q24A: 24. Values and ethics as they apply to international social work are infused into existing social work courses.

Please choose only one of the following:

Yes

No

[Only answer this question if you answered 'Yes' to question 'Q8A ' and if you answered 'Yes' to question 'Q24A ']

Q24B: Please rate the quality of the infusion.

Please choose the appropriate response for each item:

$\begin{array}{lllllll}\text { Unacceptable } & 2 & 3 & \text { Essential } & 5 & 6 & \text { Exemplary }\end{array}$

Answer

[Only answer this question if you answered 'Yes' to question 'Q8A ' and if you answered 'Yes' to question 'Q24A ']

Q24C: Please explain how values and ethics are infused and reasons for your rating.

Please write your answer here: 
[Only answer this question if you answered 'Yes' to question 'Q8A ']

Q25A: 25. Social problems as they apply to international social work are infused into existing social work courses.

Please choose only one of the following:

$$
\begin{aligned}
& \text { Yes } \\
& \text { No }
\end{aligned}
$$

[Only answer this question if you answered 'Yes' to question 'Q8A ' and if you answered 'Yes' to question 'Q25A ']

Q25B: Please rate the quality of the infusion.

Please choose the appropriate response for each item:

$\begin{array}{lllllll}\text { Unacceptable } & 2 & 3 & \text { Essential } & 5 & 6 & \text { Exemplary }\end{array}$

Answer

[Only answer this question if you answered 'Yes' to question 'Q8A ' and if you answered 'Yes' to question 'Q25A ']

Q25C: Please explain how social problems are infused and reasons for your rating.

Please write your answer here:

[Only answer this question if you answered 'Yes' to question 'Q8A ']

Q26A: 26. Human oppression as it applies to international social work is infused into existing social work courses.

Please choose only one of the following:

Yes

No 
[Only answer this question if you answered 'Yes' to question 'Q8A ' and if you answered 'Yes' to question 'Q26A ']

Q26B: Please rate the quality of the infusion.

Please choose the appropriate response for each item:

$\begin{array}{lllllll}\text { Unacceptable } & 2 & 3 & \text { Essential } & 5 & 6 & \text { Exemplary }\end{array}$

Answer

[Only answer this question if you answered 'Yes' to question 'Q8A ' and if you answered 'Yes' to question 'Q26A ']

Q26C: Please explain how human oppression is infused and reasons for your rating.

Please write your answer here:

\section{Submit Your Survey.}

Thank you for completing this survey. Please fax your completed survey to: . 
APPENDIX B

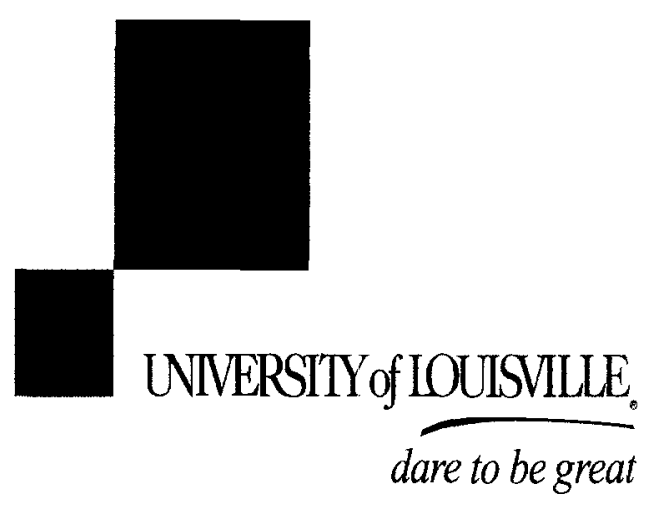

KENT SCHOOL OF SOCLAL WORK

Oppenheimer Hall University of Louisville Louisville, KY 40292

\section{Current Status of International Social Work Curriculum}

\section{Dear Dean or Director,}

You are invited to participate in a research study, the purpose of which is to learn the current status of international social work within the social work curriculum. This study is being conducted and sponsored by Stephen Ulrich, Doctoral Candidate, and Dr. Annatjie Faul at the Kent School of Social Work, University of Louisville. In this study, you will be asked to complete an Internet survey.

Your participation in this study is voluntary. You may decline to answer any question. There may be no direct benefit to you, although the knowledge gained may benefit other social work academicians/professionals in enhancing their approach to international social work curriculum. The survey should take approximately $\mathbf{2 0}$ minutes to complete. There are no foreseeable risks associated with this survey.

Although absolute confidentiality cannot be guaranteed, all data will be held in confidence to the extent permitted by law. Should the data be published, your identity will not be disclosed. Your completed survey will be stored electronically at the Kent School of Social Work, in Louisville. Individuals from the Kent School of Social Work and the Human Studies Committee may inspect these records.

By completing the survey, you are indicating that all of your present questions have been answered in the language you can understand. You may refuse to participate without being subject to any penalty or losing any benefits to 
which you are otherwise entitled. If you have any questions about this study, you may contact the co-principal investigator at (502) 836-4706. If you have any questions about your rights as a research subject, you may contact the Human Subjects Protection Program Office at (502) 852-5188.

Sincerely,

Annatjie Faul, $\mathrm{PhD}$.

Stephen Ulrich,

ABD

(Principal Investigator)

502-852-1981

(Co-Investigator)

AcFaul01@louisville.edu

502-239-8729

Sulrich208@aol.com

Committee Chair

Doctoral Candidate 


\author{
CURRICULUM VITAE \\ Stephen W. Ulrich, Ph.D., MSSW \\ Prevention Grant Administrator \\ Kentucky Department for Public Health \\ HIVIAIDS Branch \\ 275 E. Main Street \\ Frankfort, Kentucky 40621 \\ e-mail:SUlrich208@aol.com or Stephen.Ulrich@ky.gov \\ Home: (502) 239-8729, Cell (502) 836-4706

\section{EDUCATION}

Ph.D. $2006 \quad$ University of Louisville

Kent School of Social Work

Dissertation Topic: International Social Work Best Practices Curriculum For Schools Of Social Work

Chair: Annatjie Faul, Ph.D.

Committee Members: Drs. Ruth Huber, Joe Brown, Anita Barbee, Annatjie Faul, and Marie Antoinette Sossou

\title{
M.S.S.W. 2000 University of Louisville
}

Kent School of Social Work

Concentration: Macro Practice

BSW 1999 Brescia University

Department of Social Work

M.Div. $1990 \quad$ St. Meinrad School of Theology

MS. Ed 1980 Indiana State University

B.S. Ed 19 University of Southern Indiana 


\section{RESEARCH INTERESTS}

Diversity and Social Work

Social Work and HIVIAIDS

International Social Work

Public Health and Social Work

Social Work and the GLBT Community

Geriatric Social Work

Social Work and Community Building

TEACHING INTERESTS

Social Welfare Policy

Direct Macro Practice

Human Behavior and Social Environment I and II

Geriatric and HIVIAIDS

Culture, Race, Class, Immigration in Aging and HIVIAIDS

HIVIAIDS and Social Work

International Social Work

Social Work Policy

\section{RESEARCH EXPERIENCE}

GRADUATE RESEARCH ASSISTANT, KENT SCHOOL OF SOCIAL WORK

Assisted visiting professors and international social work students; organized and managed statistical data, analyzed statistical data; assisted professor with research for presentations, presented public dissertation defense in the Kent School of Social Work, University of Louisville.

2002

RESEARCH PRACTICUM IN SCHOOL OF SOCIAL WORK

Focus: International Social Work

\section{TEACHING EXPERIENCE}

\section{ADJUNCT FACULTY}

Department of Social Work

Spalding University, Louisville, Kentucky

Introduction to Social Work, Session I 2004, Session IV 2005

Human Behavior and Social Environment II, Session IV

2004, Session III 2005. 
Kent School of Social Work (MSW)

University of Louisville

Direct Macro Practice, Spring 2002

2001

\section{TEACHING PRACTICUM}

Kent School of Social Work

University of Louisville

Direct Macro Practice, Fall 2001

\section{PUBLICATIONS}

\section{JOURNAL ARTICLE:}

Ulrich, S. (2002). Can Education Affect Homophobia. Social Work Perspectives, Spring, 13(1), pgs. 28-33.

\section{CLINICAL AND MACRO SOCIAL WORK EXPERIENCE}

01/06-Present

09/04-01/06
PREVENTION GRANT ADMINISTRATOR KY. DEPARTMENT FOR PUBLIC HEALTH

Administered CDC Prevention Grant, oversaw contracts and bidding, administered memorandums of agreement with local health departments; conducted quarterly site visits to monitor agency compliance; wrote and presented reports; supervised prevention coordinators; served as state cochair of Kentucky HIVIAIDS Planning and Advisory Council; assisted prevention coordinators with quarterly prevention trainings; assisted with surveillance department for entering data; served on state HIVIAIDS conference planning committee.

\section{VOLUNTEERS OF AMERICA CARE COORDINATOR PROGRAM}

Served as case manager and advocate for clients and their families; referred clients to appropriate services; conducted assessments to monitor client progress; assisted clients in writing care plans; trained social work interns; networked with other agencies; attended supervision reviews; continued education with certified training programs; co-facilitated HIV spirituality support group. 
HOUSE OF RUTH

GLADE HOUSE DIRECTOR , HOUSING CASE MANAGER AND LIAISON, AND COORDINATOR OF HOMELESS OUTREACH

Supervised two resident coordinators; researched MQOL Survey and database of clients; QAS and Peer Reviewer for Coalition for the Homeless; assessed new clients; provided referrals for chemical and alcohol assessments and screenings; participated on Leadership Team; wrote grants; participated on the Service Providers and Legislative Committees for Coalition for the Homeless; facilitated student interns from Spalding University and served on the university's Field Advisory Committee; served as director for community home for HIV homeless men.

05/00-10/00

\section{OPTIONS FOR INDIVIDUALS}

Served as client advocate for adults with physical and mental challenges.

$09 / 99-4 / 00$

\section{SACRED HEART VILLAGE SOCIAL SERVICES COORDINATOR (PART-TIME)}

Preparing and placing MDS care plans into database; assessments and referrals for services; facilitated men's group; assisted activities director; served on Quality Assurance and Ethics Committees.

\section{PROFESSIONAL PRESENTATIONS}

Ulrich, S. (2005, March). Developing Cultural Competency for Working GLBT Clients in Alcohol and Drug Treatment Settings. Volunteers of America Staff Training. Louisville, Kentucky

\section{CONFERENCE PRESENTATIONS}

Ulrich, S. (2005, March). Stress, Spirituality, and HIV. 2005 Kentucky State HIVIAIDS Conference. Lexington, Kentucky

Ulrich, S. (2002, November). Successful Housing and Living with HIV. Second Annual HIVIAIDS Kentucky State Conference. Lexington, Kentucky. 


\section{PROFESSIONAL CERTIFICATIONS}

State of Kentucky Certified Social Worker License \#4876

\section{FELLOWSHIPS AND AWARDS}

1999

WHOSE WHO AMONG STUDENTS IN AMERICAN UNIVERSITIES AND COLLEGES, Brescia University.

$2000-2002$

GRADUATE ASSISTANSHIP, Kent School of Social Work, University of Louisville, Kentucky

2006

GOLDEN KEY INTERNATIONAL HONOUR SOCIETY, Atlanta, Georgia 